

Prenciples of

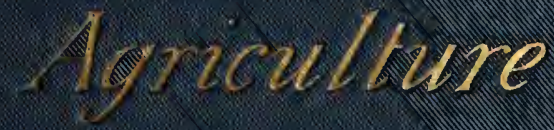

Wh sLaW 




\section{THE UNIVERSITY OF CALIFORNIA SANTA BARBARA}

PRESENTED BY

MRS. NELLIER. PREUSS 
$\frac{\text { tr.plould }}{189^{2}}$ 



THE

\section{PRINCIPLES OF AGRICULTURE}

FOR

\section{COMMON SCHOOLS}

BY

I. O. WINSLOW, A.M.

NEW YORK :- CINCINNATI : · CHICAGO

AMERICAN BOOK COMPANY

1891 
Copyright, 1890,

By 1. O. Wixslow. 


\section{PREFACE.}

A KNOWLEDGE of the principles of agrieulture, A which simply means a knowledge of the natural laws and prineiples which underlie rural life and rural pursuits, is not only important for those who are actually engaged in the pursuits of agriculture, but may in general be regarded as an important element in the education of the young.

For the large number of pupils who are unable to pursue an extended academic course of study, the natural sciences shonld not, as is too often the ease, be wholly neglected.

Although the time of the school course may not admit of a thorough mastery of any one of these sciences, a selection of the fundamental and elementary principles of each may be consistently and profitably presented.

Education of this kind, impressing upon the young the mysteries and the beanties of nature, tends to increase the fondness for our native soil, and to develop a spirit of genuine patriotism.

This book is designed primarily for use in the public schools, and eontains no difficulties too great for ordinary pupils of twelve or fourtecn years. 
It has been the aim to observe a careful analysis, sepallating the subjects inter distinct topics, and treating cach bricfly and conciscly.

Many numor and subordinate topics have been purposely omitted. 'The experience of the anthor' leads him to beliere that a thorongh knowledge of the few main points of a sulject is wortl more to the pupil than a confused irlea of the whole.

'There are many problems comnected with the subject of agriculture which have not yet been solved, and many points which have not been definitely settled. These are either wholly avoided or bricfly mentioned. There is enomgh which is established beyond question to engage the attention of beginners.

The first chapters of the work contain but little that belongs peculiarly to the seience of agrienltme, but they necessarily form the fomdation of that seience. 'They comprise some of the leading facts and principles of chemistry, natural philosophy, geology, physical geography, and botany, particularly such as bear directly upon agriculture and rural life.

The questions at the end of each chapter are inserted for the especial prupose of assisting such teachers as are not familiar with the subjects, and do not feel competent to present them. As the work is arranged, it is believed that no teacher will find any difficulty in understanding it or making it interesting.

JUNE, 1891. 


\section{CONTENTS.}

Pages

Suggestions to Teachers .

CHAPTEL I.

The Substances of the Earth . . . . . . . . . 7-25

CHAP'Tlir 11.

Land and Water . . . . . . . . . . . . 26-40

CHAPTER II.

The Atmosphere . . . . . . . . . . . . . 41-53

CHAPTEL IT.

Plants . . . . . . . . . . . . . . . 51-76

CHAPTER V.

Fertilizers . . . . . . . . . . . . . 77-99

CHAPTER VI.

Cultivation . . . . . . . . . . . 100-11:3

CHAPTER VII.

Animals . . . . . . . . . . . . 114-14t

Glossary . . . . . . . . . . . . . . 145-146 Index . . . . . . . . . . . . . . 147-152 


\section{SUGGESTIONS TO TEACHERS.}


reenire pupils to commit to memory the statements of the text, is not teaching.

The aim should be to stimulate in the minds of pupils the habit of obscring and thinking for themselves. The text shonkl simply serve as a guicle, or starting noint, for the work of the class.

This is particularly true of suljeets related to the natural seiences, like those of which the present work is composed. Many topies iu the text are necessarily treated with brevity, hut it is expected that teachers will avail themselves of the opportunity to amplify and illustrate them with familiar examples.

'The guestions at the eml of each chapter may lo used for review exorcises or for "xaminations. They may also be user in claily recitations, but teachers will natmally ask many similar questions of their own.

'The taraling will be rendered much more interesting and effectual by the free nse of olject lessons and simple experiments. Those who are aceustomed to teath the natural sciences and are supplienl with apparatus for the pmopses, need no sugrestions upon this point.

The ontfit of a rhemical laboratory is not necessary, lowerele ats the ingenions teaher will find abmolant means for the jurporer within reach. Specimens of rocks, soils, and plants from the neiwh. loring fields, pots of soil with a few varietios of secels and of fere tilizers. for expreriments in the growtl of plants, a small puantity of some common and familiar chemicals purelased fol a few cents of the nearest apothecary, and a small mieroseope, cither pureliased or borrowed for oreasional use, are anomg the means available.

It will surve a useful pmpose, partionlarly with the oleler pupils, to have at hand. for reference and comparison, other works on chemistry, geolowy, plessical geogralphy lotany, and agriculture.

The subjert is naturally interesting, ant. if wisely presented, can not fail to afforel enjoyment to both teaclier and pupils, and to yield satisfactory results. 


\title{
TIIE PRINCIPLES OF AGRICULTURE.
}

\author{
CHAPTER I. \\ THE SUBSTANCES OF THE EARTH.
}

Simple Substances. - All matter of which the earth, the atmosphere, and all plants and animals are composed consists of a comparatively small number of simple sul)stances or elements.

We are accustomed to think of the ordinary objects about us as simple in their nature, and as composed of but one kind of matter.

This is true of a few substances, like pure gold, silver, and iron; but the greater number of the objects with which we are familiar are composed of several simple substances mixed or combined.

Water is composed of two gases. Wood may be divided into ten or more different elements. If we burn a jile of wood we see the smoke, we know that there are gases escaping which we eannot see, and we find a small quantity of ashes remaining. Neither the smoke, the gases, nor the ashes appear at all like wood, and yet we know that in some way the wood has been transformed into these substances. 
The whole number of elementary sulsstanees at present known is from sixty-five to serenty. Some of them. however, are very rare.

Ouly fourteen elements are generally found in soil, plants, and animals. Knowledge of these is of importance in the sturty of agrienlture.

They are as follows:-

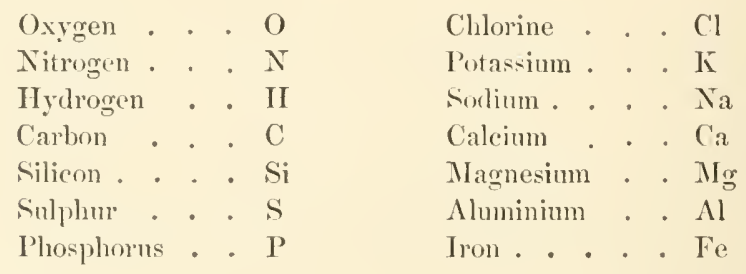

These mames are used so often that, for ennrenience, they are abbreviated, earh being represented by one or two letters. The abbreviations are called'symbols. The symbols for potassinm, sodium, and iron are taken from the aneient and forrign mames of those substaness.

Atoms. - All matter is composed of minute particles called atoms. These are su small that they have never been seen. We eannot even imagiue the size of them. Millions of atoms might rest upon the point of a pin.

The helief that they exist is cmbolied in what is called the atomic theory. This theory is bolieved to be true, becanse all known facts are eonsistent with it. All the facts in nature with which we are arquainted, and the results of all exporiments that have erer been tried, are just what they would be if the theory were true. T'he fact that atoms eannot be seen is no reason for donbting their existence. We are linited in our power to see and mulerstand. As we are muble to comprohemb the distance to thre smu, and the immensity of space, so, on 
the other hand, we cammot form any idea of the minnteness of matter.

Powerful micoseopes have resealed forms of amimal life which had never lefore heon concerived of. It is known that multitudes of living being's maly oceupy a single drop of water.

An atom is the smillesit particle into which matter can be divided. Tre may repeatedly sublivide a piece of geold until it is reduced to tlos thousand-millionth part of an ommec, and yet we shall be far from rouehing a singte atom. If it were possible to

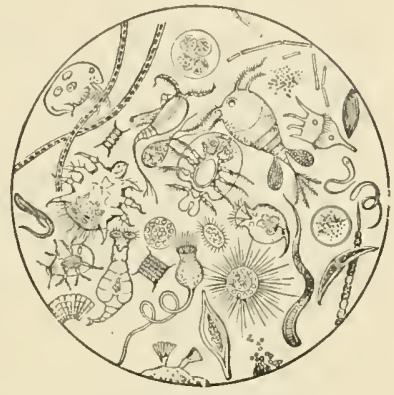

A Drop of Water.

(M/rynified.) contimue the proesss long emough, a particle would finally be ohtained which ambl no longer be divided or changed in any respect.

An atom of oxyen is always exactly the same, whether it forms a part of the soil, or of the air, or cuters intu the structure of a plant or an animal.

An atom is represented by the symbol which is nsed to kenote the kind of sulstance. The symbol $O$ may denote a quantity of oxyen in goneral, or an atom of oxyen. A number of atoms is indicated by a figure written below, and to the right. O, denotes two atoms of oxyen, $\mathrm{H}_{6}$ six atoms of hydrogen.

Molecules. - Atoms do not ienerally exist alome. They possess a force of attraction which eanses them to mite with other atoms, either of the same kind or of a different kind.

This force is called chemical affinity. It canses atoms to 
unite in regular groups. A group of this kind is called a molecule, which means a little mass.

'Two atoms of hydrogen miting with one of oxyen form a molecule of water. 'Twolve atoms of carbun, twenty-two atoms of hydrogen, and eleven atoms of oxygen, produce a molecule of sugar.

Molecules, though larger than atoms, are yet too small to he seen.

A molecule is rejresented by writing together the symbols of the different kinds of atoms of which it is connposed, giving the number of atoms of each kind. The expression $\mathrm{H}_{2} \mathrm{O}$ represents either a molecule of watel or wates in general. $\mathrm{H}_{2} \mathrm{sO}_{4}$ denotes sulphuric acid, and indicates that in a molecule of the acid there are united two atoms of hydrogen, one of sulphur, and four of oxygen.

When more than one molecule is to be represented, the number is indieated by a figure prefixed. $2 \mathrm{CO}_{2}$ represents two molecules of arlonic acid.

In all molecules of the same sulistance the atoms are supposed to maintain a uniform order of arrangement.

They always hold regular positions with respect to mach other. The positions kepend rpon the relative degree of attraction which the atoms have for each other.

The alrangements are supposed to be somewhat like the following: -

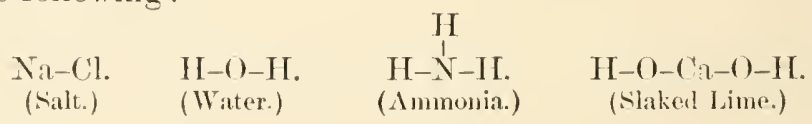

The Nature of Matter. - The nature of any sulsstance depends mpon the nature of the molecules of which it is composed. It may he entime different from the substances whose atoms mite to form the molecule. 
Hydrogen and nitrogen are both odorless, but when mited they form anmonia $\left(\mathrm{NH}_{3}\right)$ which is noted for is strong odor. Chlorine alone is pois.mons, lut with solinu it forms common salt ( NaCl). The great ralriety of dilferent kinds of matter is produced by the great number of possible combinations of atoms of the elementary substances.

Chemical Action. - Molecules are the smallest particles into which a substance ean be divided without changing its nature. Whaterer change is wronght upon matter, its real nature remains the sime so long ats its indiridual molecules are not broken ㄲ.

A substance may be nelted, or eonverted into a gas, or mixed with some other substance, and yet it is the same substance; but if its molecules are divided into their separate atoms, and these unite again with other atoms in different combinations, it is no longer the same.

The force which divides molecules into their separate atoms, and permits them to form other combinations.s, as to produce new sulsstances, is called chemical force, or the chemical action of one sulsstance upon another.

When two molecules of different kinds are bronght together, if some of the atoms of one are more strongly attracted by atoms in the other than by neighboring atoms in their own molecule, one or both of the molecules will be broken up and new molecules will be formed.

When water is poured upon quicklime, the atoms of the water molecule unite with those of the lime molecule, forming molecules of a new substance, or slaked lime.

When some of the atoms are not needed in making up the new molecule they are set free. If pieces of zine are placed in hydrochlorie acid, the chlorine of the acid will 
mite with the zine, and the atoms of hydrogen mite with one another, forming molecules of free hydrogen.

Chemieal forec sometmes clanges the mature of a substance by simply changing the allangement of atoms in its molecules. Flue molecules of eane sugar, and those of gum arabie, for instance, contain exactly the same number of corresponding atoms $\left(\mathrm{C}_{12} \mathrm{H}_{22} \mathrm{O}_{11}\right)$. 'There are other instanees in which the same is true. The only explanation of this is that the atoms must oecupy different positions with respect to one another in the molecules of the different substances.

Chemical Equations. - The action of chemical foree in breaking up molecules of diffremet kinds when they are bromght together, and forming new molecules, is represented by an equation.

In the case of water and lime the equation is:

$$
\underset{\text { (lime.) }}{\mathrm{CaO}}+\underset{\text { (Waler.) }}{\mathrm{H}_{2} \mathrm{O}}=\underset{\text { (Slaked Lime.) }}{\mathrm{CaO}_{2} \mathrm{H}_{2} .}
$$

For zine and hychochloric acid it would be:

$$
\begin{aligned}
& 2 \mathrm{HCl}+\mathrm{Zn}=\mathrm{ZnCl}_{2}+\mathrm{II}_{2} \text {. } \\
& \text { (Acid.) (Zinc.) (Ziue ('hloride.) (IIşdrogen.) }
\end{aligned}
$$

In the latter case it requires fwo molecules of the arid to combine with one of zinc, forming a molecule of rinc "hloride and liberating two atoms of hydrogen.

Acids, Bases, and Salts. - There are three general elasses of substances rith which wo most become acouninted in oreler to molerstand the chemical principles of agriculture.

They are called acids. bases, and salts.



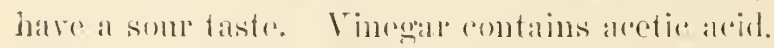

some of the more commom acids are: sulphurie arol 




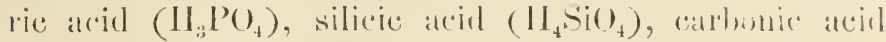
$\left(\mathrm{CO}_{2}\right)$, nitric alcid $\left(11 \mathrm{NO}_{\mathrm{i}}\right)$, etc.

Bases are a class of substances whose nature is rer? different from that of acids. A portion of them atre called alkalies, or alkaline substances, and have a hot, sharp taste.

Some of the bases are potash $\left(\mathrm{K}_{2} \mathrm{O}\right)$, sodium ( $\mathrm{Na}$ ), lime $(\mathrm{CaO})$, magnesia $(\mathrm{MgO})$, oxide of iron or iron lust ( $\mathrm{FeO})$, etc.

Acicls and lrases have a strong attraction for one another, and when united form a class of sulstances called salts. They are so named beeanse many of them have a taste similar to that of common salt.

They are called sulphates, chlorates, phosphates, ete, as clilorate of potash $\left(\mathrm{KClO}_{3}\right)$, phosphate of lime $\left(\mathrm{CaOP}_{2} \mathrm{O}_{3}\right)$, nitrate of soda $\left(\mathrm{NaNO}_{3}\right)$, ete.

Gypsum, or land plastre, is sulphate of lime and water. It is the result of a combination of sulphuric acid and quicklime:

$$
\mathrm{II}_{2} \mathrm{SO}_{4}+\mathrm{CaO}=\left(\mathrm{CaSO}_{4}+\mathrm{H}_{2} \mathrm{O}\right) .
$$

Phosphate of lime is produced by a mion of phosphoric acid and quicklime:

$$
2 \mathrm{II}_{3} \mathrm{PO}_{4}+\mathrm{CaO}=\mathrm{CaOP}_{2} \mathrm{O}_{5}+3 \mathrm{H}_{2} \mathrm{O} .
$$

If a feather is dipped in hydrochloric arid and hold over an open bottle of ammonia, the ammonia, escaping by evapolation, will unite with the acid and form a white powder upon the feather, called ammonic chloride:

$$
\mathrm{NH}_{3}+\mathrm{IICl}=\mathrm{NII}_{4} \mathrm{Cl} \text {. }
$$

When the two parts of a rochelle powder are dissolved and fomped together, the acid of the one mites with the base of the ofluer, prohueng a salt, which remains dis- 
solved in the watel" ant arbonic acid, which escapes in the form of a gas, cansing the effervescence.

Cohesion and Adhesion. - Is atoms have attractions which ealuse them to mite in molecules, so the molecules themselves have similar attractions for one another.

When the attraction is between molecules of the same kind, it is called colesion; when between molecules of diffrent kinds, it is callerl adhesion.

Molecules of water have an attraction of cohesion for one another, but the alhesion between water and glass is sufficient to overeome this, and to canse a piece of glass to he moistened when dipened in water. On the other hand, an oily stick will not be moistened by water, beeanse the cohesion in water is stronger than the adhesion between water and oil.

'The aclhesive attraction of water for gases canses the moisture of the atmosphere to absorb impuritios and bring them down with the rain.

The attraction of chareoal for rarions substances renders it useful as a filter for cleansing water, refining slugrar, ete.

In order that the forees of colesion and adhesion may act, it is necessary to bring the molecules rery near to one another. In hreaking a picce of iron, we exert a foree upon it sufficient to pull its molecules so far apart that the force of cohresion no longer acts.

ln wreler to weld the separated parts it is necessary to heat throm motil their molecules will move more easily, and then beat them togother by hammering until the molcenles are again hronght within the range of cohesive forree.

In strotching a piece of rubber, we draw the molecules farther and farther apart, until finally the force applied 
is sufficiont to overeome the foree of cohesion hy which the molecules are attracted to one another, and they are separated or the rubber is broken.

The Porosity of Matter. - All matter is mole or less porous. 'This is not ouly true of loose substances like soil, but also of more solid substances, like wood and iron. The pores in the latter are, like atoms and molecules, too small to be seen.



Cross-section of Wood, magnified, showing Pores.

I, the barl: $C$, the cambinm layer; W, wool.

It is believed that neither atoms nor molecules ever remain in absolute contact with each other, but that there are always spaces hetween them. Through these spaces atoms and molecules of other substances are able to pass.

A certain amomnt of salt and sugar may be dissolred in water without increasing the rolume of water. 'The molecules of salt and sngar ocenpy the vacant spaces hetween the molecules of water.

Under heary pressure water has heen forced through the pores of irom. A piece of iron may be made smaller by hammering. Its molecules are then driven nearer together.

$\Lambda$ bottle filled with gas will hold as much of another kind of gas ats if it were empty. 
Solids, Liquids, and Gases. - Matter exists in one of three states: cithor as a solid, a liquid, or a gas. The same substance may assume one of these forms at one time, and another at another time.

The state is supposed to depend upon the degree of attraction by which its molecules are bound together.

When they are firmly united, the substance is a solid. When the force that binds them is weaker, allowing them to more freely upon one another, it becomes a liquid. When the force is entirely overeome, it becomes a valpor or gas. 'The molceules then fly apart, tending to occupy as much space as possible.

The state of a substance is partly dependent upon the temperature.

Heat tends to orercome the attraction, and so to change a substance to the liquid or gaseons form. A moderate amount of heat will change a block of ice, first to water and then to vapor. A higher temperature will produce a similar effect mon other solids.

Heat, by overeoning the folce that draws molecules together, increases the distance between them, and so increases the space which they oceupy and the size of the body. So, on the other hand, a low temperature allows the molecules to come nearer together, and renders the body smaller.

There are a few exceptions to the general rule that heat expemls and cold contracts. When water is cooled enomgl to freeze, or become a solir, it is errstallizerl; that is to say, its molecules arrange themselves in cer. tain forms which require more space than if they were pareked elosely together. The same is true of at few other sulstanees when ehanging from the liquid to the solid state. 
The expansive force of water in fleczing, or crystallizing, is rery great. A pitcher filled with water, and allowed to freeze, is sure to be broken. 'The moisture of the soil in freezing beneath a building lifts it pereeptibly erery winter.

Snowflakes illustrate the tendency of freezing water to erystallize. When examined with a microseope, they fresent a great variety of regular forms whose beauty and accuracy it would be difficult to imitate.

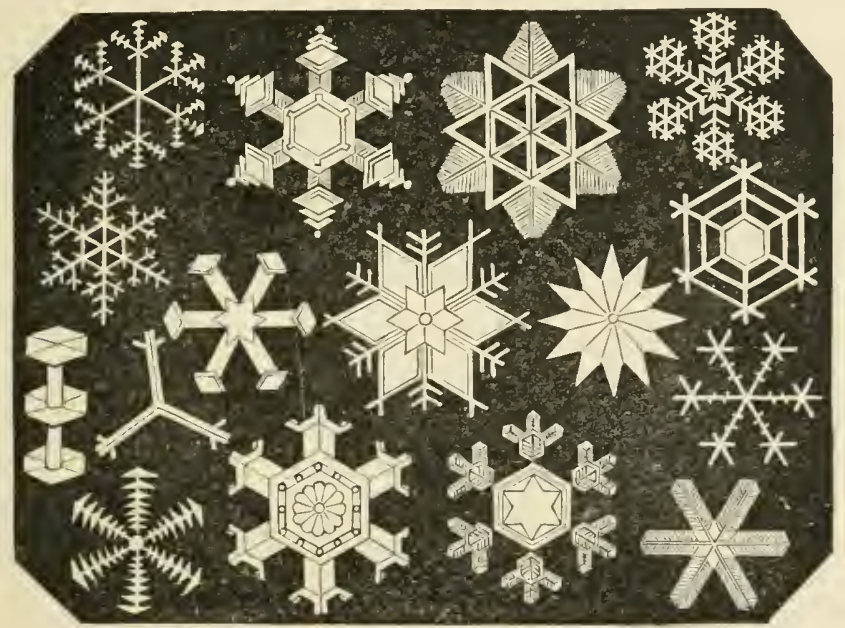

Snow Crystals.

Other substances, like sugar, salt, and alum, show the same tendeney. When these are dissolved in water, as their molecules slowly come together again by the evaporation of the water, they tend to arrange themselves in regular forms.

Organic and Inorganic Matter. - Matter is sometimes dividel into two classes: oranic and inoreanic.

Wixs. Agre -2 
Oreanic substances are those which have been converted into living organisms; or, in other words, which either form or have formed a part of the bodies of plants and animals. They are prodned by the processes of life. All other matter is alled inorganic.

When orwaic matter is hmed or decays, it returns again to an inorganic condition.

Pieces of stone or iron, for instance, are not organic, because they have no organs such as exist in anything which has life. On the other hand, wood, hay, flesh, and bones are examples of oreanic matter, since they have been produced by the growth of living plants and animals, and retain the same matter and the same form which they had when in a living state. Soil may he partly organic and partly inorganic, since it not only contains mincral matter, but also vegetalole and animal matter, left by the death of plants and animals, which has not yet become so far changed as to lose its organic condition.

Organic substances have never been produced by artificial means. For articles of food, - fruit, regetables, and meat, - as well as for the materials used for cloth. ing, - cotton, wool, linen, and silk, - the workl must depend upon nature's proeesses in agriculture.

All attempts to imitate nature by producing these substances have failed.

Combustible and Incombustible Matter, - Wlien any sulstance is burned, some of its elements escape into the atmosphere in the form of gases and floating proticles, and the remainder beeome ashes. The carbon unites with the oxyen of the alle and escapes as earbonic acid gas. Some of the nitrogen is converted into ammonia gas. 'The water is converted into rapol. 
The elements which escalpe include the carbon, hychegen, oxygen, and nitrogen, and sonetimes the sulphur. The remaining clements are found in the ashles. The former are called combustible or volutile, and the latter incomblustible or fixed.

The following is a brief description of the more conn$1110 \mathrm{n}$ elements :

Oxygen is the most common and interesting of the elements. It forms about one half of the solic parts of the earth, eight ninths, by weight, of all water, and one fifth of the air. It has powerful attractions for many other elements. The sulstances formed by its mion with these are generally called oxides. Water $\left(\mathrm{H}_{2} \mathrm{O}\right)$ is sometimes called hydric oxirle. Lime (CaO) is calcic oxide; iron rust ( $\mathrm{FO})$, ferric oxide. There are three familiar processes in natnre in which oxygen takes a leading part:-

1. Combustion. - The ordinary process of burning, or combustion, consists of the union of the oxygen of the air with earlon and some other elements of the fuel. This mion with carbon produces a gas $\left(\mathrm{CO}_{2}\right)$ called carbon dioxide, or carbonic acid gas.

Heat is a result of the mion. It is regarded as a kind of forec. The force or clash with which atoms come together in burning is converted into another kind of foree called heat. The degree of heat depends upon the rapidity of the proecss. A draft through a fire in. creases the heat, because it furnishes a larger supply of oxygent.

2. Oxidation. - ln the rusting of metals, and the decay of wood, a process is going on precisely similar to that of burning, except that it is mirch slower. New combinations are formed, and the same amomit of licat 
is produced as if the iron or wood were bumand, or oxidized more rapidly. The process is so slow that the heat is not noticeable.

'The decomposition and decay of all substances, in general, is largely a process of oxilation. Articles of food are preserved from decay by separation from the oxygen of the air. 'The decay of soft regetable substance, as well as the crumbling of the hardest rock, shows the power of oxygen in transforming the products of nature.

3. Respiration. - Respination or breathing in animals is similar to combustion and oxidation. The oxygen of the air, taken into the lungs, enters the blood, where it unites with carbon. The carbonic acid gas thus produeed escapes with the breath into the atmosphere.

The leat which results from this miom serves to keep up the temperature of the body of the animal. The amount of heat per day produced in the system of a man by breathing is about equal to that obtained by burning a pound of coal.

Plants breathe to a slight extent, taking in oxygen through the pores of their leares, and giving off carbonic acid gas.

Hydrogen is the lightest substance known. It weighs only one sixtecuth as much as oxyuen. It combines most readily with oxygen and chorine. When burnow or combined with oxygen, it forms water. It is an essential part of plants and animals. It is produced by the decay of animal and regetable matter, or from molecules of water, by separating it from the atoms of oxygen.

Nitrogen, in a free state, forms fomr fifths of the air. It is an odorless and hammless gas. Its purpose in the air serms to be to dinte the oxygen with which it is mixed and diminish its force. 
It forms an csscential pait of plants and animals, and is of great importance for agricultural purposes. Its force of attraction for other elements is rery weak. 'This fact increases the difficulty of retaining it in permanent forms. It is the most expensive part of fertilizers. With hydrogen it lorms ammonia $\left(\mathrm{NH}_{3}\right)$; with lydrogen and oxyenen, nitric acd $\left(\mathrm{HNO}_{3}\right)$. These are the two forms in which nitrogen most commonly becomes a source of fertility, and of importance in agriculture.

Carbon is found in nature in three forms: as chareoal anl similar substances; as graphite, which is used in making lead pencils; and as diamonds, which ale simply crystallized carton.

It forms a large part of all animal and regetalle sulhstances. Coal, wood, and woody sulistances are largely composed of it. It is the element which gives value to substances used as fucl.

Chareoal, which is largely composed of free carlon, is produced by burning woor in a partially smothered fire. The process releases the carlon from other elements with which it is combined, and retains it by exchuling the orygen of the air, with which it would otherwise unite and escape as carbonic acid gas.

If a piece of wood is placed in sulphuric acid and allowed to remain for some time it beeomes black. The acid remores the other elements of the wood and leares the carloon.

If a piece of glass is held orer the flame of a candle it becomes "smoked," or covered with minnte particles of carbon, which escape faster than they can be consmmed.

All plants contain a large proportion of carlon. In cotton fiber it is almost pure. Sugar, which is a product of plants, is forty-two per cent. carbon, by weight. 
Silicon is the most abmolant solirl substance known. It forms about one fomrth of the sulid parts of the carth. It is commonly combined with oxygen in the form of silica $\left(\mathrm{KiO}_{2}\right)$. Quartz rock is a rariety of silical. It forms a lalge part of gramite rock, sanrlstome, and common sand. It serves, like an acid, to mite with bases, forming what are called silicates. Common glass is a mixture of dilferent silicates. Clay is chicfly composed of silicate of almmina.

Silica is found in plants, particularly in the grasses. It gires to the stalks and hranches greater firmuess and harduess.

Sulphur is a familial substance, eommonly known as brimstone, or flowers of sulphur. With hydlogen and oxygen it forms sulphuric acid $\left(\mathrm{I}_{2} \mathrm{~s}\left(\mathrm{O}_{4}\right)\right.$, one of the most common acids. This acid forms a great variety of useful salts, as sulphate of potash $\left(K_{2} \mathrm{~s}_{4}\right)$, sulphate of lime $\left(\mathrm{CaSO}_{4}\right)$, ete.

Sulphur is always fomm in plants and animals. The strong flaror of such regetables as tmmips and onions is due to the presence of sulphur.

Phosphorus is a soft, yellow snbstanee, which mites with the oxygen of the air and takes fire so easily that it ean only be kept moder water. It is used in mannfacturing matches. It combines with lyedrogen aml oxyoren, forming phospluoric acid $\left(\mathrm{H}_{3} \mathrm{PO}_{4}\right)$, a substaneo of great importance in fertilizers. It forms about ten per eent. of the bones of animals, in the form of caleimm phospliate.

Chlorine is a gas which is fomm only in combination with ofluer elements. With hyrlerenen it produces lydrochloric or muritic acirl (HCl); with sodimm, sodim chloride or common salt ( $\mathrm{NaC}$ (') 
Potassium is a soft, light substance, whose affinity fol' oxygen is so strong that it can only le kept pure in some substance containing no oxygen. When placed upon a piece of iec it bums freely.

With oxygen it forms potash $\left(\mathrm{K}_{2} \mathrm{O}\right)$, and with oxygen and hydrogen caustic potash (KOH). Potash mites with acids producing a valiety of salts of potash, as chlorate of potash $\left(\mathrm{KClO}_{3}\right)$, sulplate of potash $\left(\mathrm{K}_{2} \mathrm{~S}()_{4}\right)$, ete.

Sodium is somewhat similar to potassimm. It forms a great variety of salts, of which common salt ( $\mathrm{NaCl}$ ) is a familiar example. Caustic soda is preparced in large quantities for mamufacturing soap.

Calcium is a common substance, found in combination with other elements, from which it is not easily seprarated. In limestone and marble it is mited with carbonic acid, forming calcium carbonate $\left(\mathrm{CaCO}_{3}\right)$.

Compounds of calcium constitute a large part of the shells of clams, oysters, and other shell-fish, and also of the hones of all animals.

Magnesium is a metal fomd in some rocks. The pure metal burns brilliantly, and is sometimes used for illuminating pmposes when a rery strong light is required. It is fomd to some extent in plants and animals. With oxygen it forms magnesia ( $\mathrm{MoO})$.

Aluminium is somewhat similar to magnesimm. It resembles silver in aplearance. It is used to a small extent in making jewelry and ormamental work. The sapphire and ruby are beautiful forms of alumina. It exists largely in common clay in combination with silica.

Iron is found in many parts of the carth in the form of ore, which is pmified and used for mannfactming purposes. It exists to some extent in all soils. It gires clayey soils their dark brown color. 


\section{QUESTIONS.}

How many different elementary sulstances are there in the earth? Name those which are most common. Name as many others as yon can think of. What is meant by the symbol of a substance? Nime the symbols of the most common substances.

What is an atom? IIave atoms ever been seen? IIow do we know that they exist? IIow are atoms represented? Give an islea of the size of an atom. Can an atom be divided? ('an it be destroyerl?

What is a molecule? What causes atoms to form molecules? How is a molecule represented? IIow are the atoms of a molecule arranged?

Lpon what does the nature of matter depend? Must all substances compecel of earbon, hydrogen, and oxyen be alike? Can the molecules of a boily be broken or divided? Ilow can this be done? What effect does this have nyom a body? What would be the effect of making a different, arrangement of the atoms in the moleenles of a substance?

What is chemical action? Give an example of chemieal aetion, and exjlain it.

What are acids? Bases? Salts? Name some of each.

Give a ehemieal equation showing how hases are foimerl.

What is colesion? What is alleesion? Why does you hanl heeome wot. when dipped in water? Why are the feet kejt dry by greasing the boots? How is water purified by leaching thromgly rharcoal? Why are not two pieces of wood touching each ofler helel torcother by eohesion?

How many porous substances are there? IIow do we know that iron is jorons? Why can silt he added to a glass full of water withont causing it to run over? Why may two gases appear to oceupy the same space at the same trume?

Explain the difference heween solicls, liguids, and gases? Why is a substanee melted by heating it? IIow is it that heat expands and cold contracts? Whly does water exprand in freezing?

What is the differenee letween or anie and inorranie matter? Is hay oreanic or incmanic? A poilto? Water? Mlik? Sand? Ordinary soil? 
Explain the differenee between combustible and incombustible matter. Mlention some common substanees which are partly eombustible. Mention some which are entirely combustible. Name some that are entirely incombustible.

How much oxyen is there in the earth? What is an oxide? Explain the proeess of huming. What is heat? Why does a fire burn better in a clraft of air? Why has decayed wood lost a part of its value for fuel? Why do we seal fruit to preserve it? How dues breathing lieep the boly warm?

What are the peenliarities of lyclrogen? Why is water produeed by burning hydrogen? Where is nitrogen to be found? Why is it so cliflicult to obtain it for practical purposes?

Name some oljects that enntain carbon. What proportion of the earth is silicon? Nime some forms in which it is found. Name some of the uses of sulphur. Deseribe phosphorus. Name some nseful forms of chlorine.

Describe potassium. Name some of the salts of potash. Mention some useful forms of sorlinn Where is ealcium fomm? IIow may magnesium le distinguished? Name some forms of aluminium. Where does iron exist? 


\section{CHAPTER II.}

LAND AND WATER.

The Former Condition of the Earth. - The carth has not always been as it now is, but has been gradually changing through long periods of rears. It is believed that it was once very hot, - so hot that all the solid sulstances now nom it were melted, or converterl into galses. $\Lambda$ s it gradually cooled upon the outside, some of these liquids and gases beeame solid, and formed a crust «pon the surface. It is beliered that the interior of the earth remains to the present day in a very hot condition. There are several indications of this:

1. In deseending into the earth, after passing below the effeet of the sum's heat, the temperature lieenmes higher the farther we deseend.

2. Earthquakes are, in some way, due to morements of the melted substances or gases, or of the crust above them.

3. Some of the hot liquids and gases are often poured forth from roleanoes.

It is hardly to he supposed that the whole of the earth's interior is a liquid, because, white the temperature may be sufficiontly high to melt all known substanees, the immense pressure moler which all matter is placed at any great depth below the surface must be sufficient to retain it in a solid form, notwithstanding the excessive heat. 
As the proeess of cooling went on, the moisture of the atmosphere becane condensed ; and, falling as lain, corered the carth's surface with water.

Out of this jumitive earth, this crust of mincral substances, and the water and atmospluere surromeling it, and out of the plants and bodies of animals that lave lived and died upon its surface, have been furmed the soil and rocks of our present earth.

The Age of the Earth. - The processes by which this great change has been brought ahout have been, for the most part, silent and gardual. Many of them ale still going on. Our earth, with the variety of sulstances uyon it, is not to be considered as a thing completed, but as eonstantly undergoing (hanges in the great workshop) of Nature.

The period of time that has clapsed since the first solid crust was formed must he exceedingly long. Some of the lowest estimates made by careful students lave been from fiftecn to twenty million years.

Continents. - It is a common principle in nature that heating a body causes it to expand, and cooling causes it to contract, or become smaller. Now, it is impossible for a spherical body, with a solid surface, to become smaller without forming upon its surface dents aur ridges, or depressions and elerations. As the ancient earth became still cooler and smaller, after having first formerl a crust, it was natural that this erust should become irregular in shape, produeing low and high places. The water naturally sank into the lower places, learing the elevated regions as continents.

The continents that thus first appeared above water were rery small, and gradually increased in size, extending their coasts as the contimued shrinking of the crust 


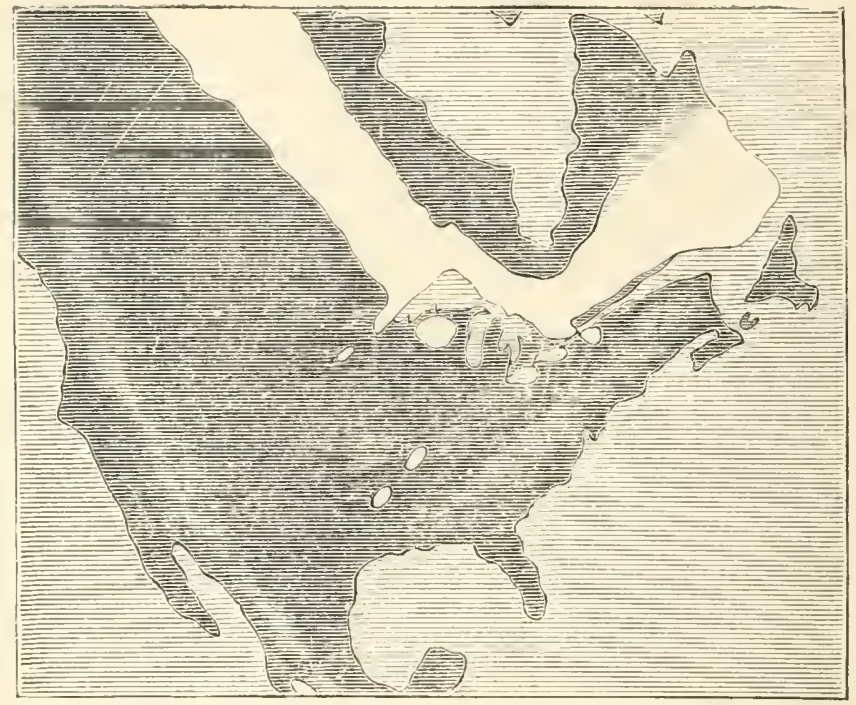

The Beginnings of North America. (White indicates land.)

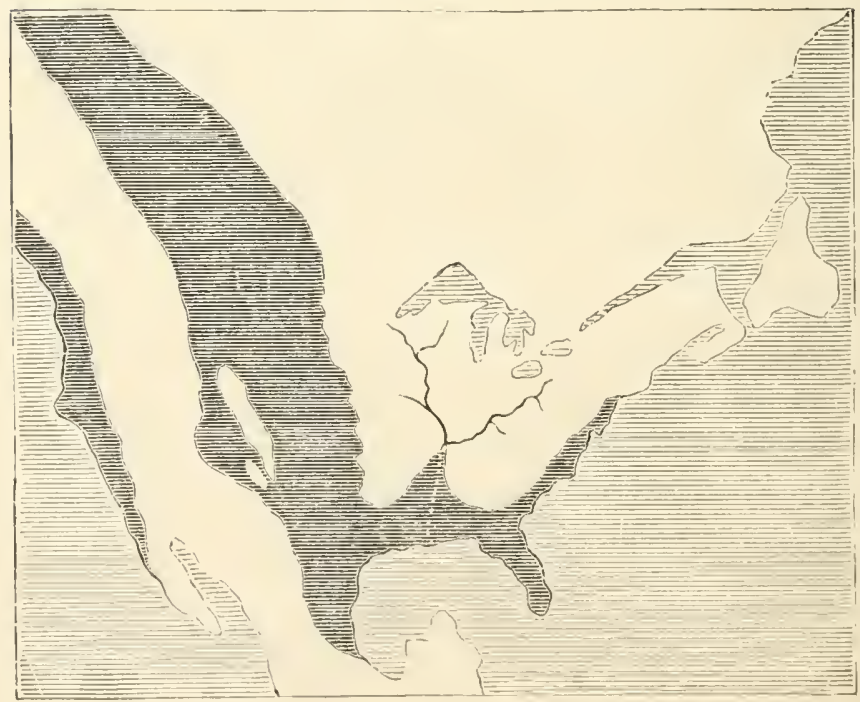

North Americ in the Seco:dary Ers. (White indicates land.) (2.) 
raised them more and more abore the level of the water. The first appearance of the North Anerican continent was in a small, angular section, cxtending from the Great Lakes northeast to Labrador, and northwest to the Aretic Ocean.

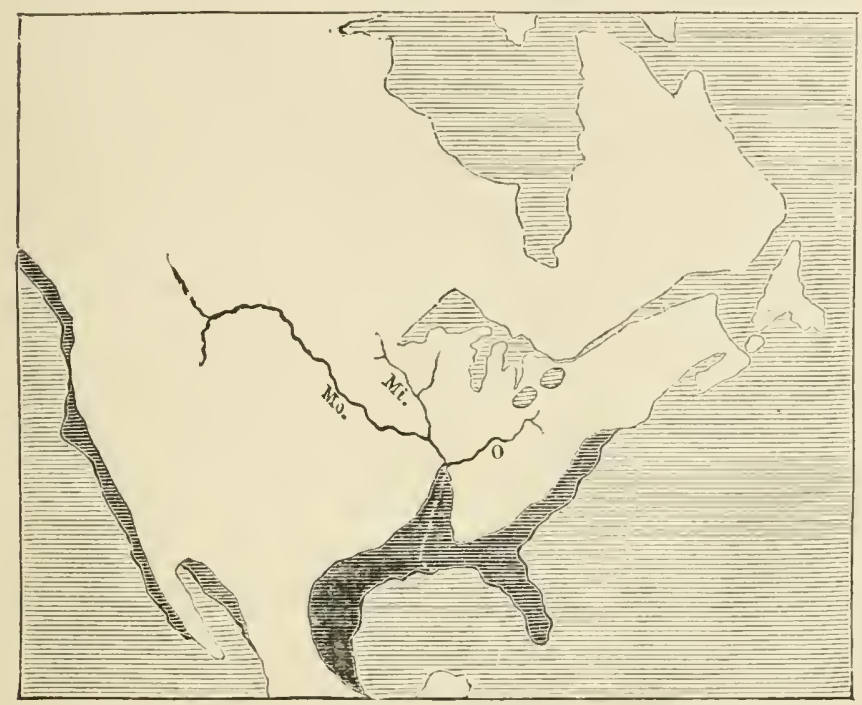

North America in the Tertiary Era. (White indicates land.)

Mountains and Hills. - The cooling and shrinking of the contincut has also giren rise to mountain ranges and valleys. The inwarl juessure and sinking of certain sections cansed long eracks in the earth's crust, and the npturnerl edges have formed some of the great momtain ranges of the earth.

Some mountains have also becu formed by an accumulation of molted matter pourcel from these cracks and from roleanoes. 
Nany of the smaller hills have been formed by bociies of moring water and ice, which have gromd ont valleys betworn them.

'The formation of hills, and other changes upon the face of nature, have been brought about gradually. Falling rains and rumning streams are slowly reducing the size of the hills by wearing them away and carying them to the valleys below. In some cases. on the other hand, swift rmming streams and rivers are wearing ont and incleasing the depth of the valleys between the hills.

The Soil. - If we examine some soil with a mieroseope, we shall find that, while it contains some other substances of a different nature, a large part of it is composed of fincly divided particles of rock. 'These are enenally of a similar nature to the larger rocks that are seattered through the soil, and have been produced from large rocks by the grinding and crmmbling forees of nature.

'The greater part of our present soil, howerer, was not formed directly ont of the original rocks of the first erust of the earth. The soil formed by the first crumb. ling of the original rocks generally solidified, or petri. fied, inter rock again, and this process of ermbling and solidifying continued through several alternations until our present soil was formed.

Nearly all the present rocks were at some time soil. Conglomerate stomes, sometimes called "pudding-stones," are examples of an ancient soil, containing stones of different kincls, which has been transformed into solid rock. Sanclstone was once a leed of simel.

Specimens of rocks from the original erust are now to he fomel only in a fow scatfered lowalities in those seetions which fust appearerl abore water, where, ly rintue 
of their elevated position, they have partly eseaped the forees that would tend to destroy them.

'The process of rock-making is still going on. 'There is often to be fomml, beneatl the sulface soil, a stratum of "hard pan," thromgh which it is diffienlt to penetrate. This is gradually becoming solidified by the action of chemical forces, and at some time in the distant future will become stonc.

The chief agencies in nature which have done the work of grinding rocks, and preparing the soil of the earth, are:-

1. The Atimosphere. - Nearly all rocks, when exposed to the atmospliere above gromnd, mdergo chemical changes "yon their surface by which portions are continually crumbling and falling off. This effect npon some rocks will cause them to waste away in a rery few years, while with others the process is much shower.

Some varictics of sandstone are found near the surface, so much affected by the atmosphere, which has reached them through the porous soil, as to be easily crumbled into powder.

The most enduring kinds of marble, used for erecting momuments, are generally covered with fine marble dust, showing that eren they are not exempt from the universal tendeney.

2. Running Wuter. - With every shower and rain storm, and with the melting snows in spring-time, streans and brooklets are constantly wearing away the rocks, and washing away soil from the sides of liills and momtains, and carrying it into the rivers below. As the current of the river becomes less rapirl, this soil settles, forming deposits on the banks of the river at its month, or on the neighhoring shores of the ocean. 
When the streams and rivers are much swollen, they Wash out and hear away many rocks in their swift culrent. As these are lobled and tmmbled one mpon another, they are aroumel into soil, which is added to the genoral deposit. 'The momntains and hills are thus glatelmally carred away to fill the valteys below, and to extend the coasts of the continent. 'The rich alluvial lands in river valleys have been formed in this way.

3. The Oeenn. - The morements of water on the shores of the ocean produce an effect similar to that of rivers. The flow and rbo of the tide, and the breaking of wares on the bealeh, grind rocks into sand, or wash up, shells from dreper water, grinting them into fine poweler. 'This

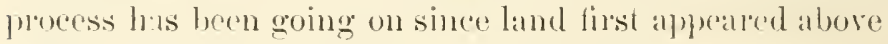
water, forming the oricin of our continest.

The oedan has been continually forming herls of sand and mad on of neale its shores. 'Theso have luen raised above the surface, as the waters have recerled, and in many ases have lecome consolidated into rook. Simclstome and limestome have leorn mostly produend in this mamele, the former from the stmel herls, and the litter from mud formed by the arimcline of shells. A similar effect has hean protuced by laroe lakes, some of which have becone entirely dry, leaving deposits of samd, lime, or other mineral matter.

4. Ire. - Iee fomming in the crarks and creviees of rocks, year after year, tends by its explumson to hurst the rockis or open crevices. thus arhitting the atmosphere, and hastruing the work of ermmblinge.

Minute particles are also detached feom the poeks by the freezine and thawing of the moisture mon their smefare. If a number of ream stomes ale plared in a fail of fume water, and the water is allowed to frecze 


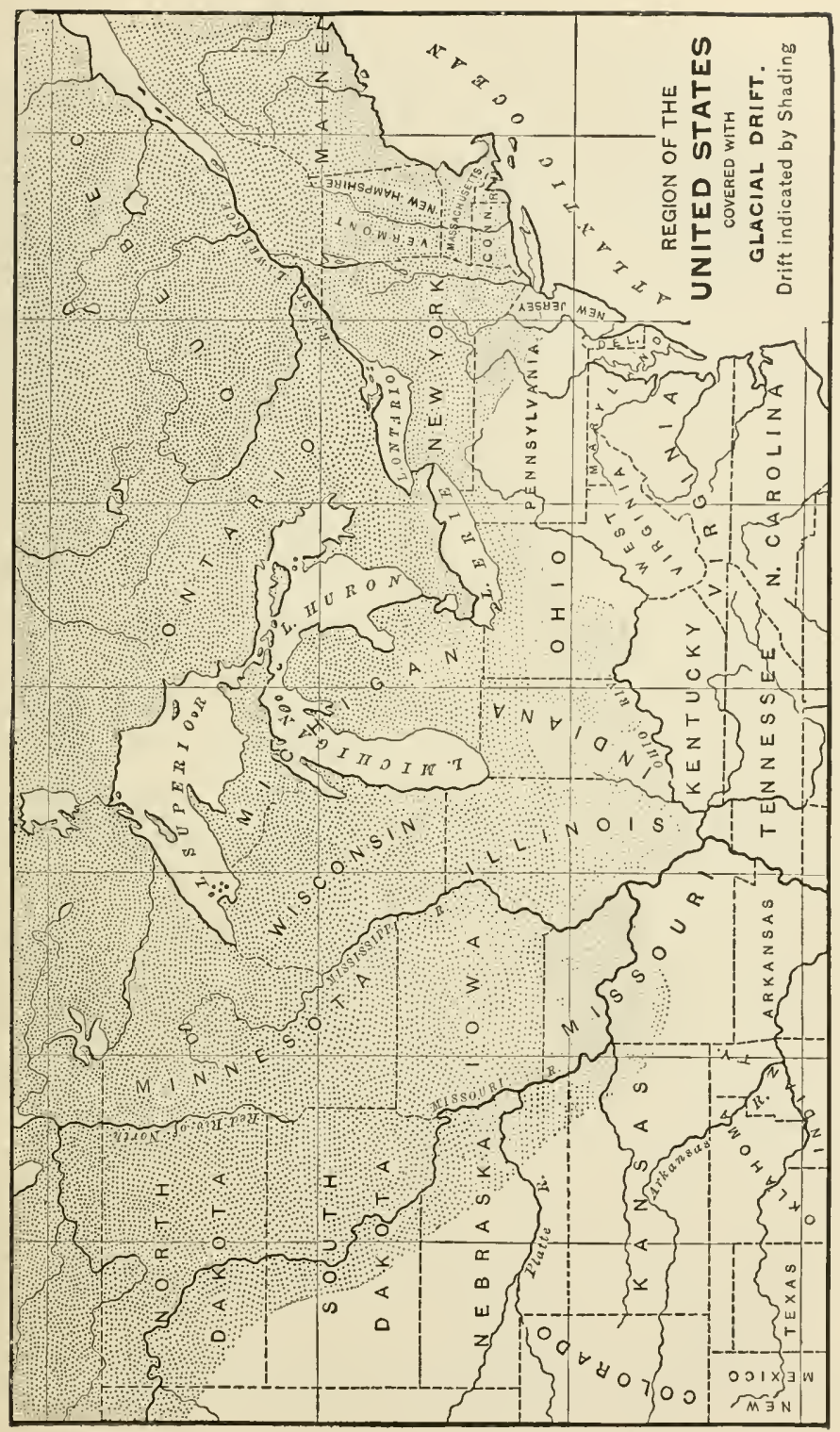

(33) 
and thaw several times, there will he found a preceptible quantity of fine particles at the bottom.

but the greatest effect of ice in forming soil, and changing the face of nature, has been throngh ylaciers.

In ligh, momntainons regions, and in cold latitudes, snow steadily aecumulates, forming immense masses of iee in the deep ralleys. 'These are steadily, but rery slowly, jushed along by their own weight until they reach a lower and warmer region, where they melt away. 'These huge rivers of moving snow and ice are called glaciers. Rocks in the conrse of the glacier are torn up and borne along, grinding upon one another, and grinding paths thromgh other solid beds of rock, until they are deposited as bowlders and soil at the point where the glacier melts.

It is believer that, at some time in the history of the carth, the regions to the nortl of the equator hecame for a time much colder than at present, causing perpetual snow to fall upon large portions of North America and Europe, dere enomgh to hury most of the hills and mountains breneath rast, eontimoms queiers.

'Tlese glaciers, mowing towarel the equator, gromel enormous quantities of rock into soil, and deposited it ores" a lalese rextent of comitry, together with the rocks which romained ungromel. Huge bowlders, as well as smaller rorks, seatteled orer the combly, may be traced hack morthward mamy miles, to their original bod. In Now Eneland they hare heon carried two or thee hmmdreal miles, and in the Mississippi Valley one thomsand milas. Soil and rocks which lave heen transported in this way are called drift.

5. Wimds. - Winds have also taken some part in form. ing soil, and especially in changing its location. In 
some sandy regions, large rocks have been partly worn away by the sand which has for centuries becon blown across their surface. Whole hills hare, in some instances, been thus worn away and depositer in other localities.

The Composition of Soil, - The soil of the earth may be considered as composed of fom different classes of substances :-

1. Finely Divided Partirles of Rock. - Crumbled rock, or sand, constitutes the bulk of many varieties of soil. bren soft, peaty soil will be found, npon careful examination, to contain a greater or less pereentage of gritty substance.

2. Decaying Vegetable Matter. - Nearly all kinds of soil contain more or less of a soft, pasty, dark-colored sulstance called humus, or regetable mold. The grass, leaves, and falling trees, which are continully acemurlating upon the surface of the soil, and are mixed with it by cultiration, furnish a perpetual sourec of this humus. It forms a large part of the peaty soil found in low places. In peat or muck beds it is nearly pure.

Peat, or swamp muck, is an accummlation of regetable matter which has been formed through long perjods of the ancient history of the earth.

In low, marshy places, certain kinds of rank regetation lave grown year by year, or from age to age, and, falling, lave been burjed one upon another in water and mud. These aceumulations have undergone a process of slow decay, or smothered combustion, mucler water, which has reduced them to a miform mass of black or brow matter. The dark color is due to the presenee of carthon which results from the slow combustion, as charcoul is obtained from the smothered burning of wood. 




(36) 
In some eases, in low places, the process hals heen continued further, until the peat has been petrified, or converted into eoal.

Peat beds are rery numerous. Sonne of them are of very large extent. 'The great "I ismal Swamp," of North Carolina is a rast peat beel.

Many of the smaller muck swanlus are partly eomposed of ordinary suil, which has been washed in from the surounding hillsides.

3. The Remains of Animuls. - The homes and shells of all the great numbers and rarieties of animals that have lived and died on the land, and in the ocean, have contributed to the formation of eertain kinds of soil. Limestone, and limy matter in soil, have becen produced from shells which have aremulated in the ocean, and in lakes which have beeme dry. The rock of coral reefs, and the soil formed by the crumbling of such rock, are largely composed of the remains of minute animals.

The hones of land animals, when decomposed or gromol, add desirable elements to the soil.

4. Sulstances formed by Chemical Action from the three Classes mentioned. - The presenee of these sultstances gives fertility to the soil. Neither arumbled rock, nor the remains of plants or animals, in their crude original condition, would furnish any food for the support of plants; but by chemieal processes in the soil new eombinations are grarlually formed which are adapted to the support of regetalse life.

Soils are eommonly elassified areording to the sulstamees of which they appear to be largely eomposed, as follows :-

1. Samdy. - Pure sand, which is composed entirely 
of particles of quintz rock, would be of little value for ancicultural purposes. It eam furmish no food for the support of plants. It is generally, howerer, mixed with other substances which give it some fertility. Samely soil has hut little power to retain moisture. Rain water realily souks thromgh it and rums away. Fuch land suffers severely form a dromght. It is, furthermore, mable to letain for any length of time the supplies of plant food which are formed in it or added to it. 'These substances are washed out as water passes through it. It is ealled light soil, and has the atrantage of being easy to till. It beconnes diy and warm enongle for cultivation earlier in the spring than other kinds of soil.

2. Gramlly. - Gravel is like samb, except that the rocks of which it is eomposed hatre not becn grommel so fine. Gravelly soil is largely composed of rocks gromel to various degrees of fmeness. It has the same ecueral properties as sandy soil. When nearly pure, it is pren less valuable than the latter for agricultural plilposes.

3. Clayey. - Clay consists of certain kinds of decomposed rock. Pure clay, of itself, contains but little plant food, but it possesses in a remarkalle degree the molerty of absorbing and retaining other sulstances which tend to render it fertile. Fertilizers which have been applied to elayey soil are retained for a long time, until withdrawn by growing crops.

Water leaching thromgh such soil is found to come away as pure as when it enters, washing away no raluable substances.

It is called heary soil. Water passes through it very slowly, so that it cammot be tilled mutil late in the spring, or for a long time after heary rains. If handled and 
pressed together when wet, it has the peenliar tendency to form hard lumps, requiring ensidcrable labor to pulverize them and provide a fine seed-bed for crops.

4. Peuty, or Mucky. - This is one of the most valuahle kimls of soil for agricultural purposes. It emusists of a mixture of ordinaly soil with large quantities of regetable mold. It has great power to retain noisture through periods of dry weather. It contains large supplies of some kinds of plint food, which are gradually converted into suitable form to meet the demands of sucerssive erops year after year.

5. Limy, or C'ulcureous. - Most soils contain some lime. In some cases the quantity is so laree as to give a name to the soil. The raricty of soil called marl contains large quantities of earbonate of lime.

The lime in soil selves to some extent as food for plants, as all plants require a small quantity of it. It also serves a good purpose indireetly, as a base, by combining with acid substanees in the soil, and forming salts which are desirable as plant food.

6. Loam. - This is simply a general name applied to ordinary soil, which contains a mixture of the varieties mentioned, combined in raried proportions. If quite sandy, it is called sandy loan; if quite elayey, elayey loam.

\section{QUESTIONS.}

What was the oriqinal conclition of the earth? How dit the surface become solicl? What is the present condition of the interior of the earth? Ilow dowe know it? What caused the appearance of water upon the earth? Inow old is the earth?

How were the rontinents formed? Explain the origin of mountain ranges and hills. (Of what is soil largely composed? How has it been formed? Give the history of most of our present rocks. 
Is any of the first "rust of the earth still in existence? Name the five nitural agencies that have ground rocks into soil.

What is the effect of the atmosphere? What work destreams anel rivers perform? What has the ocean done? Explain the eflect of iee upon rocks in winter. What is a glacier? Where are glatciers to be found at the present time? Ilow have glaciers assisted in forming soil? What has been the effect of winds?

Name the classes of substances of which soil is composed. Explain the origin of humus, or vegetable mold. Give the history of the formation of peat heds. What is the origin of limestone? Name the different varieties of soil. Give the peculiar properties of each. 


\section{CIAPTER III.}

THE ATMOSPIERE.

THE atmosphere inclules the air and other gases 1 and rapors which smround the earth. Its composition is as follows: -

1. Air. - Air forms the bulk of the atmospliere. It is composed of oxygen and nitrogen, in the proportion of one part oxygen to forr parts nitrogen. The two are not chemically united into molecules, but the molecules of each are thoroughly mixed together. It is the oxygen of the atmosphere that is essential to plant and animal life. The purpose of the nitrogen seems to he to dilute the oxygen and reduce its fores.

2. Water Vapor. - There is always present in the air, and distributed through it, mole or less muisture, or vapor of water. The quantity varies from one fifticth to one two-hundredth part of the hulk of the air. This moisture lasses into the air hy evaporation from the surface of loodirs of water, from the surface of the land, and from all moist substances.

We are reminded in various ways that the air contains moisture, as in the diops that form upon the outside of a pitcher of cold water, in the moisture that accumulates upon the window-pane and forms a thick corering of frost in winter and in the moisture that appears upon the grass in the morning. 
When the air becomes overeharged with moistme, the surplus comes to the earth again in the form of rain.

3. Carbonic Acid Gas. - The chicf somrees of this gas in the atmosphere are the breathing of animals, the buning of fuel, and the decay of manic matter.

It is thrown off from the systems of amimals as uscless, but is essential to the life and growth of plants.

It may be seen that the escaping breath contains earbonic acid, by breathing through a tube into clear limewater. There will be formed in the water a white powder, which is callowate of line, prodnced by the union of the carbonic acted and the lime.

Althongh the ail always contains some callonic aced gas, when too large a duantity is present it becomes poisomous. For this reason it is mwholesome to slere in a small, elose room, without some rentilation, or for many persons to remain long in any elosed room. The burning of lamps in a room, or the decay of regetables in a cellar, produces the same effeet as the breathing of persons, hy adling to the proportionate anomet of carbonic aeil gas.

4. Impurities. - The ail rontains small quantities of various substances, as ammonia, nitric acid, ete., besides smoke and dust.

'These are largely absolbed by the water rapor, and homght to the earth in raindrops. They give rain-water its dark color, and remler it of some ralue as a fertilizer for erops.

Weight of the Atmosphere - T'hr atmospluere lias wright as truly as the objerets which we cau sere and hanelle. The height, or distance from the anth to which it extencls, is not defuntely known. It is varionsly estimated at fonn one lumbled to five hundred miles. 
It produess a pressme npon every spot efprial to the weight of the whole colum abore. This pressure amounts to about fifteen pounds nom exery square inch.

The pressure is not simply upon the top of an object, but upon the sides and mulerneath as well. It is not like one solid body resting "yom another. The partickes of gases and liquids move abont so freely that the pressure upon any object contained in them is erenly distributed in every direction.

As the pressure of the air is erculy balaneed npon all sides, we are not comscious of it.

Upon the ontstretehed ham there rests a column of air that woukl weigh two or three humdred poumls. We are not eomscions of it, because there is an equivalent pressure underneath the hand to support it. When the pressure underneath is removed ly placing the hand upon the reeciver of an air-pump, and exhausting the air, the pressure upon the top becomes painful. If the moistened palms are rubihed closely together, so as parttially to remove the air, some foree is required to pull them apart. If the air is remover from the montly ly expanding the lungs, the pressure of air ont side forecs the cheeks inward.

The atmosphere near the earth is more compressed and heary than at some distance above it, hecause there is more air above to press down. There is a marker difference between the pressure and density of air in a valley and on a high momtain.

The barometer is an instrument for determining the pressure of the air. It really consists of a tube scaled at one end, filled with mercury, and inverted into a cup or lag of merenry. The pressure of air upon the mer- 
cury in the cup or bag forces this np into the tuhe mntil the colmmn of mercury in the tube is heary enough to halance the pressure of the air. The heaver the air, the more it will press, and the highel the colmmn will

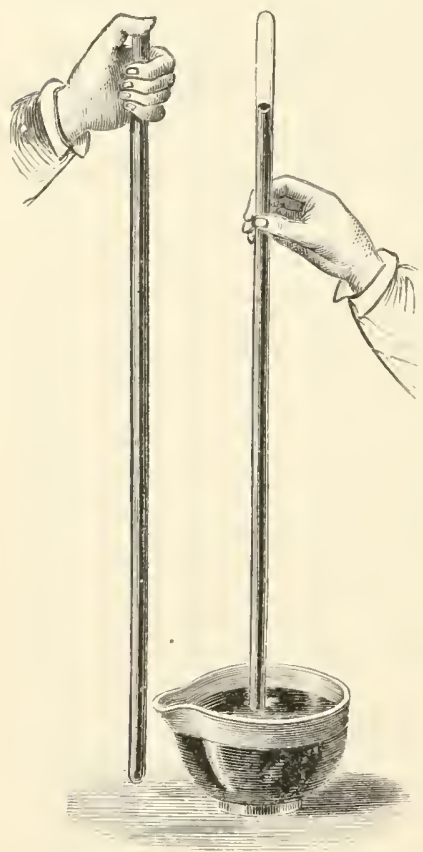

A Barometer Tube. rise in the tube. On the other hand, the lighter the air, the lower the columm will fall.

Changes of temperature and morements in the atmosphere canse the weight and pressille to vary. As this variation is correctly determined hy the baromeder, this instrmment becomes of great service in calenlatung probar ble changes of weather.

Temperature. - The thermomoter is nsed to determine the temperature, or the amomut of heat that the atmosphere contains. It consists of a tube, with a bull, at the lowes end, containine mereury or aleolob. On the principle that loat expancls and cold contuats, when the atmosphere hecomes warm the melectry or alcohol expands and rises in the tuhe, and as the atmosphere becomes cooler it contrads and falls.

Winds. - Since the atmosplure is invisible, we are apt to forget that it exists, mutil reminderl by the foree of the wind that it is a real substance. Wind is simply 
air in motion. Its foree depends mon the rate at whicll the air is moving, vangug flom a slight motion, which gives al gentle brecze, to a velocity of forty or lifty miles per hour, producing a hurricine, a tornado, or a whirlwind.

Cause of Winds. - Winds are always caused by the unequal density or weight of different portions of the atmosphere. This is generally due to differences in temperature. It is true of the air, as of other substances, that heat expands it, making a given bulk of it lighter; and that cold contracts it, making a griven bulk heavier. If a quantity of oil is poured into a bocly of water, the water, which is heavier, will push the lighter oil to the surface. So, if the atmosphere in any locality bocomes warmer and lighter than the surrounding atmosphere, the latter will push it into the upner regions, and will rush in to fill the space underneath.

The high wind that accompanies a thunder-storm at the close of a hot day is due to the fact that the atmosphere, which has been heated during the day, is now rapidly rising, while the cooler atmosplere around is rusling in.

The land and sea lreezes, which are common on the sea-coast, are due to the umequal heating of the atmosphere over land and water at different times of day.

Rain. - Rain is an accmmulation of the vapor of the atmosphere into drops, which, by their weight, fall to the ground. There is a limit to the quantity of watel' which the air is capable of alsorlune and retaining as an invisible rapor. When it contains as much as possible, it is said to be saturated. Now, warm air is able to hold more moisture than cold air; hence, when air which is saturated hecomes colder, for any reason, it can no longer 
retain all its moisture. A portion is liberated, acenmulates in drops, and falls to the earth. This is in all rasos the explanation of rain.

'The dillerent ways in which the air is cooled, and rain is producerl, are:-

1. By Rising into the Upper Regions. - Jhe ligher we ascent from the carth's surface, the coolel we lind the atmosphere. Momntains are sometimes clotled with grass and flowers at the foot, while their summits are corered with prepetual suow.

The atmosphere is wamed chicfly by the wam earth. The heat of the sum's lays is accmmulated upon the surface of the earth. The earth then, like a heated store, throws out or radiates its heat, and wams the atmosphere. So, as in case of the stove, the atmosphere nearest it is always the warmest.

As the air in any locality lecomes heated in this way, it is pressed "uward by cooler and hearier air from other sections, where it is cooled; and, if it contains sufficient moisture, rain is produced.

Ascending air is also cooled hy expanding. When air is compressed so as to ocenpy a smaller space, it becomes warmer. On the other hand, when air expands, it beemes cooler. As the air asemels, the pressure mon it from the air above becomes less, and consequently it expands and becomes cooler. This, of itself, is a comnom eanse of rain.

2. By Passiny over Mountains. - Mills and momntains are sometimes called "rain condensers." As the rising curpents of air pass orer momntainoms regions, the air ex. pands and is cooled, and parts with its smplus moisture. Hilly regions are more abmombly supplied witle rain than level tracts. 'That side of a range of momtains 
Which the wind reaches first in its customary conrse receires more rain than the offmsite side, since the currents of air lose moisture in passing over it. 'The ahsence of rain on some parts of the cuast of south Ameriea is due to the fact that the wind, which blows constantly from the east in those regions, cumses the atmosphere to deposit rain, and become eomparatirely dry in passing the Ancles Momintains.

3. By the Hixture of Wurm and Cool Currents of Air. - In the changing courses of rariable winds, warm currents of air often meet and mingle with cooler currents. Whon the air is saturated, this is liable at any time to canse rain.

Snow and Hail. - Snow and hail are frozen forms of atmospheric moisture. In the case of smow, the minute particles of moisture are frozen as they form, and arrange themselves about each other in beantiful crystals, producing the snowflake.

Hailstones are often formed by whirling currents of wind, which carry raindrops or minute snowballs first into the ruper, colel regions, where they are frozen, then downward through a warmer section, where more water is alled, and then upward again. The size of the stones is thus gradually increased until they become too heary to be carried upward again, and are flung to the earth.

Fogs, Mists, and Clouds. - These are all of the same nature. They are simply particles of water or ice which hare formed at points where currents of air of different temperatures meet each other, but not in sufficient quantity to prortuce raindrops.

Clonds are formed wherever the air, in rising, is cooled cnough to condense rapors, When the air is quite dry, 
clouds will not he formed until a high point is rached, if at all. When it is well satmated, they may be formed so low as to tonch the earth, and ane then called fogs or mists.

Dew. - Dew, like rain, fog, ete, is cansed ly the cool. ing of the atmosphere. 'The earth during the night becomes eooler than the ail above it, and temils to condense moisture from the air which comes in eontatet with it.

There is less dew on a clomly night, because clonds prevent the eath from cooling. They obstruct the las of heat as these pass from the earth, and tum them back, thus preserving an equality of temperature between the earth and the air.

A strong wind prevents the formation of dew by keering the ail well mixed, and leaving no part of it in contact with the ground long enough to becone cool and deposit moisture.

A slight breeze increases the amount of dew by removing those portions of air which have already deposited their moisture, and hringing other portions sucessively in contact with the gromurl.

The quantity of water that forms mpon the gromm as dew is much larger than is generally supposed. It is only a portion of it that appears in the morning on the blarles of glass. A large part is absolved into the soil.

In Corat Britain, whore dews ale heary, it is estimated that the whole amomut dopesited in a rear womld he equal to a llepth of sereral inches of water. In some tropical regions it is deposited so fast as to be equal to a light lain.

Frost. - Frost is simply frozen moisture from the atmosphere. When the temperatme at the point where dew would form falls below 320 , the point at which water 
freezes, the moisture condensed from the air, instead of forming dew, forms crystals of ice, or frost.

When there is no dew, there ean be no frost of this kind, and regetation is not injured unless the temperature falls low enough, and remains low long enough to fleeze the sap within the plant.



Isoluars, prery ${ }_{1}^{2}$ the of an incle difference of pressure.

............. Isotherms, erery 10 drgrees temperature.

"Lon" " C'enter of ciplone.

"Iligh" = Alicyclones.

Direction of wind de clear weather.

$\gg$ - path of Cyclone.

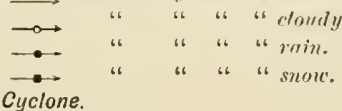

Weather Map.

The Weather. - The changes of weather which are constantly taking place are not irrenular and aceidental. They oceur according to eertain laws, and as the result of certain causes. By ascertaining these eauses, it is possible to prediet changes, so that a storm, or a cold or warm ware of temperature, may be foretold some hours before it appears.

WIxs. AG. -4 . 
The provision made by the United states for noting conditions, and annomemen indications, in all parts of the conutry, is of eleat importance. It is of great value in arriculture. The farmer, relying npon these indications, may seloct farorable weather for planting his secd or harresting his crops.

Storms. - The central section of a storm is noted ly an area of low harometer, or low pressure. 'That is to say, it is where the atmosphere is lighter than usual, and on that account is rising. In front and in the rear of the storm center, the harometer is high, or the atmosphere is heary. In the United States, these sections of low pressure, which mark the location of storms, are gencrally long and narrow, cxtending across the country fiom north to south. Storms usually appear first in the western or sonthern parts of the country, and more in an easterly or northeasterly direction.

Naturally, the winds on both sides of the storm center blow toward it. They are the hearier sections of air passing in to take the place of the lighter scetions, which are rising; hence, storms are generally preceded by east, northeast, or sontheast winds, and followed by west, northwest, ol southwest winds.

Climate. - The climate of a region is its condition with regarl to heat and moisture. It may be considered a hot or cold, a moist or div climate.

The temperature in any locality depends chiefly upon the following emditions :

1. Lutitude. - The extent to which the carth and the atmosphore near it become hoated depends upon the directness with which the rays of heat from the sun fall mrom it. Sections near the proles are therefore colder 
than those near the equator, which have the sun more directly overhead.

2. Elevation. - As the atmosphere is cooler the higher we ascend, so the climate of elerated tracts is colder than that of low plains and valleys. Although the high regions leecive the full benefit of the smm's heat, they lose heat rapidly, since the atmosphere in these regions, being thin and dry, fermits the heat to pass off easily by radiation.

3. Nearness to the Oeenn. - The tentency of the ocen is to render the climate uniform, - cooler in summer and milder in winter. As the water 11 ron the surface of the ocean becomes heated hy the smm, it mingles with the conler water below. This prevents the surface water from becoming very warm, and from inparting heat rapilly to the atmosphere.

As the ocean has stored a large amonnt of heat, and has become heated to a considerable depth, it is not quickly cooled as winter approaches, but parts with its warmth gradually during the entire winter.

The solid land, on the other hand, foes not beeome heated to a great depth. The heat of the sun is concentrated upon its surface, and is more readily radiated into the atmosphere.

In the fall of the year the ground is more quickly cooled, and has less influence in tempering the severity of winter.

Near the enast, the climate is rendered comparatively miform by receiving the benefit of cool winds from the sea in summer and mild winds in winter.

The amomt of moisture depends mostly upon the nature of the surroundings and the direction of prevalent winds. 
Ililly and momntainous regions, which the winds reach first in their usual course, are generally well supplied, while more level regions farther on have a drier climate.

\section{QUESTIONS.}

Of what is the atmosphere composed? What are the two elements of air? Whieh of them is the more important? Of what use is nitrogen in the air? Ilow much water vapor does the air contain? Where does the air get it? What becomes of it when there is more thin the air ean looll? In what three ways is the earbonic acid gas of the atmosphere formed? Name some of the impurities found in the atmosphere. What finally beeomes of these?

How much does the atmow phere weigh? Why is its pressure greater in a ralley than on a mountain? Is the atmospliere leavier or lighter in stormy weather?

What is a barometer? Why does the larometer fall before a storm? In which direction does the atmospluere presis? Ilow many pounds of air rest unon your outstretched hand? Hlow are you able to lift so great a weight?

What is a thermometer? What eauses the mercury to rise and fall in a thermoneter?

What is the wind? What eauses the wind to blow? Deseribe the direction of the eurrents of air in a room with a hot stove at one sirle. What eanes a sea breeze in a hot day on the coast? Why is a thunder-shower usually awompanied by wind?

What is rain? In what three ways is rain protuced? Why is the air always warmer near the earth than away from it? Why are hills and mountains enoler than low plaees? Why is there genesally an abundance of rain on that side of a mountain range from which the wind blows?

What is snow" Explain the formation of hailstones. W'y does it sometimes hail when the trmperature is below the freezing point? How can it snow when the temperature is above freezing?

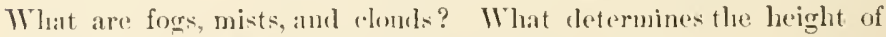
clomds? Why is it always clomly before it rains?

Explain the cause of dew. Ilow do clouds prevent the formation of dew? Why is there no dew upon a windy night? What is the 
effect of a slight breere? Give some itlea of the druantity of dew. What causes drops of water to form "ypon a pitcher of cold water on a hot day?

What is frost? When is frost liable to oceur, and when not? Epon which side of a winclow does frost forms? Why is there le'ss frost on the windows of a vacant room than on those of a room full of people?

Are the clianges of weather accidental? What is the work of the Weather Burcan, established by the government? Of what advantage is it to the farmer? What is the general cause of a storn! Describe the general course of storms in the Cnited States. Which way do the winds natmrally bluw at the time of a storm, and why?

What is meant by elimate? What three general conditions determine the tempurature of a locality? Why is the temperature orer the ocean more uniform than orer the land? Why are winters usnally most severe in the center of a continent? What generally determines the amount of rain in any lociality? 


\section{CHAP'TER IV.}

\section{PLANTS.}

Seeds. - The growth of a plant begins with the seed. A seed contains all the essential parts of the plant itself, ready to be extended ontward into the soil and into the atmosphere as soon as favorable conditions are supplied. This minnte plant formd in the seed is catled the "embryo," or "germ."

Besides the germ, a seed contains a quantity of food, stored np, to supply the young plant as it begins to grow,
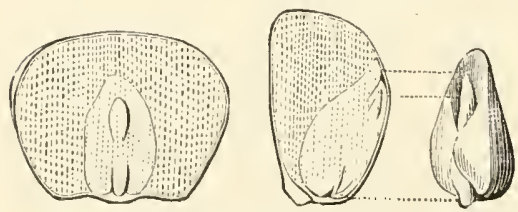

Sections of a Grain of Corn, and the Germ detached. until it is able to provicle for itself from the soil and the atmosphere.

In the "chit" of a kernel of corm, and at the "ere" of a bean, the embryo is to be found. The remainder of the seed is composed of starch and other substances for the young plant to feed upon.

The Vitality of Seeds. - Different rarieties of seeds differ greatly in the length of time they maintain their vitality, or power to spront and produce growth. The seeds of some trees will not sprout at all after once becoming dry. On the other hand, some seeds, if kept dry, will grow after many years. When sealed away from the air, these seem to retain their ritality almost (54) 
indefinitely. Peas are saicl to have spronted which were taken from an kgyptian mumny three thousand years old.

It is better to seleet new seeds for planting. Older seeds may grow, but will generally produce weaker plants.

Unripe Seeds. - Seeds used for planting shonld always be thoroughly ripe. The loss from planting unripe corm, or "pinched" wheat, may be many times as great as the extra cost of better seeds.

While the difference in yield resulting from poor seeds nay not always be apparent the first season, if the practice is contimed through a nmmber of years the crop will "rm out" and beeme unprofitalile.

On the other hand, by solecting the best specimens of seeds, year after year, the crop will be greatly improved. The yield of different erols laas, in some instances, been doubled ly a continuous selection of the best scerls.

Conditions of Growth - There are three conditions required for the growth of seeds, all of which must be supplied in order to produce germination.

1. Mnisture. - When a dry seed is placed in soil, or some other moist substance, it immediately legins to absorb moisture; it swells, and if the temperature is farolable and sufficient air is supllied, it puts forth its root, and legins to grow.

The amount of moisture faroralile for growth raries with different seeds. Some varieties will grow in water, some thrive best in very moist soil, while other's require compratively dry soil.

It is bolieved that some varioties of seeds are covered with a coating through which water cannot penetrate, and that these may remain in the soil for an indefinite 
period without germinating, mil the hull is accidentally seratched, or broken, so as to achnit moistmre. 'This may account for the fact that so many weeds unexpectedly and repeatedly spring up after the soil is stired in cultivating crops.

2. Warmth. - There is a certain range of temperature within which a seed will grow, and outside of which it will fail to do so.

The seeds of some plants, whose native home is in cold elimates, will sprout at a low temperature, while others, which are aceustomed to a warmer climate, require a higher temperature. The lowest point of temperature at which wheat, barley, oats, and peas will sprout is about $40^{\circ}$, and the highest about $109^{\circ}$. The lowest for corn and squashes is about $50^{\circ}$, and the highest about $115^{\circ}$.

Although the seeds may spront at any point within this range of temperatnre, at a point near either extreme growth will be very slow, and the plants weak and small. There is a certain degree of heat for each rariety of seeds in which they will prodnce the best growth. That point for wheat, oats, and larley is about $84^{\circ}$, and for con and squashes about $94^{\circ}$. The nearer we approach to this farorable point in choosing the land and the time for planting, the better the results. The mistake is often made of planting secds too carly in the spring, brfore the ground is suffieiently warm to insure quick and strong growth. The early plant is so weakened by low temperature as to gain nothing in the end over the later plant, which thrives better, and yields larger results.

3. Orygen.-Oxygen, which is essential to support life in animals, being taken into their systems through the air in their lungs, is also essential to the life and 
growth of plants, and eren to the sprenting of seeds. Soil is always more or less porous nrat its surface, and it is filled with air, which supplies the spronting seed with oxyeren.

Depth of Planting. - Most seeds would spront and grow if dropped mpon the surface of the soil in a lainy season, when the atmosphere is damp enough to supply the needer moistme, but it is generally safer and better to cover them with soil.

The proper depth of planting will depend upon the nature of the soil, climate, erol', ete. In rery wet or cold seasons, it is better to cover the seed but little, so that it may have better access to the air and the warmth of the sum. In warm, dry seasons, it should he huried more decply, so as to secure sufficient moisture.

In some sections of the comtry, and in some special seasoms. Indian corn will thrive best when planted at a depth of several inches, while ordinarily a light covering is better.

Many kinds of seeds will not grow at all if burjed deeply. The seeds of weeds remain rlormant in the soil, mutil they are brought near the surface by plowing or harrowing, where sufficient air and heat are supplied, and then they spring up and giow rigorously.

Sceds are supposed to contain a supply of nomrishment sufficient to support the romg plant until the ascending stem ean reach the open air.

In some cases of lecp planting, while there may he oxygen enongh to produce wrowth, the supply of food in the seed becomes exhausted hefore the surface is reached, and the plant perishes.

Germination. - The process of wermination, or sprouting of seeds, includes three points. 
1. The Absorption of Moisture. - It is evident that the untritire substances contained in the seed eamot pass into the plant and support growth while in a dry state. 'The seed must be satmated with moisture, so that there may be a medium through which these substances may pass to the point in the growing plant where they are needed.

2. A Change in the Vutritive Substances. - The supplics of food stored in the seed are not generally in a suitable form to support the plant, but must first he changed. They are dissolved in the moisture, and converted by chenical proesses into the projer forms. An instance of this is the conversion of starch into sumar. The formula for stareh is $\mathrm{C}_{66} \mathrm{H}_{10}()_{5}$, and for the ghuense sugar olitained from it, $\mathrm{C}_{65} \mathrm{I}_{12} \mathrm{O}_{4}$. The latter is obtained from the former by the adition of oxyen and hydrogen.

In the process of malting harley and other kinds of grain, the aim is to obtain these same chemical changes. The grain is soaked and allowed to sprout until the starch and other substances are eomrerted into sugar, dextrine, etc. The process is then stopped hy drying, and the new substances are extracted from the grain to form malt.

3. The Production of Heat, - The changes above referred to are largely due to oxidation, or the combination of oxygen with the substanees of the seed. This, as in other instances of oxidation, poduecs heat.

If a large number of seeds are heaped together, as in manufacturing malt, the mass becomes very warm, - so much so that care is repuired to provent the grain from spoiling. This heat, dereloped in the spronting seed, is of some service at times when the temperatmo outside is too low. 
Growth from the Seed. From the seed first appears a shoot, called the radicle, which extends downward into the soil, and shortly afterward another shoot, called the plumule, which seeks to find its way upward into the air and smolight. The radicle is the origin of the roots of the plant, and the plumule the origin of the stem, with its branches and leares.

The reason why the root thus turns downward and the stem nuward is an unsolved mystery. It camnot he due to any attractive force of light 11 pon the stem, or any repelling force npon the root, as it has been found that the same dircetions are followed when a seed is spronted in the air, in absolute darkness. From this and from other habits of plants, it would seem that they are endowed with a kind of instinet, similar to the instincts of animals. Some plants always turn their leaves toward the sunlight, while others turn them away. Some flowers close in the afternom and open in the early morning. These faets we cannot account for with certainty, in a seientifie way, any more than we ean ac-

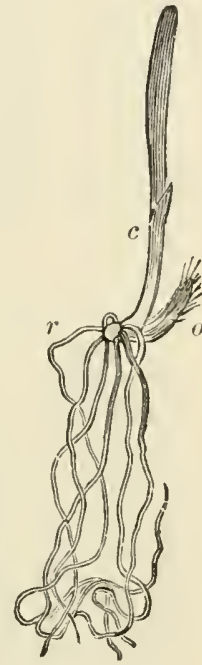

Germination of Wheat.

$o$, the grain, containing the coty. ledon: $r, p l u m u l e ;$ $r$, rudicle. connt for the very principle of life which eanses the seed to begin to germinate and its growth to continue.

Two Worlds for the Plant. $-\Lambda$ plant has two worlds, or feeding grounds: the atmosphere above and the soil beneath. One is as essential to the life and welfare of the plant as the other. As plants cannot live when their roots are withdrawn from the soil, so also most plants will die if the portion above the surface is repeatedly cut 
off. Out of the soil and the atmosphere they obtain the foorl which snstains their life and growth.

The Food of Plants. - If we analyze the substances of which a plant is composed, and ascertain the elements which it contains, we shall know exactly what food it reyuines, and what the soil and atmosphere must contain in oreler to afford proper nourishment.

The following elements are fomed in all plants, and ale essential to their growth: carlon, hydroyen, oxygen, nitrogen, sulphur, phosphorus, potassium, calcium, mugnesium, and iron. Besirl's these, there are generally

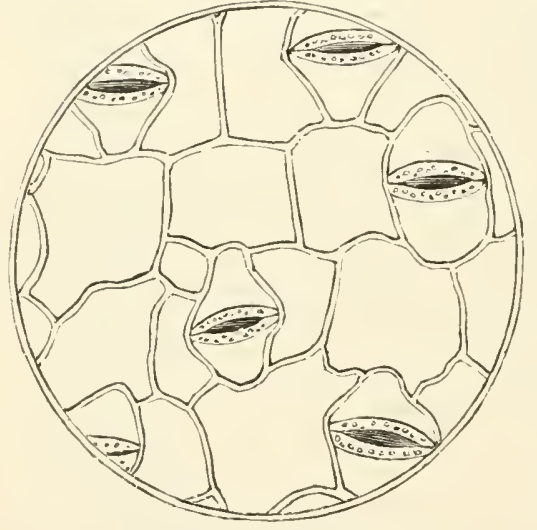

The Under Side of a Leaf.

(Magnified, shouring Cells and Mouths, or Stomatu.) found sodium, silicon, chlorine, and traces of some other substances.

Food from the Atmosphere. - The food which plants obtain from the atmospliere is mostly carbon. The leares absorb carbonic acid gas $\left(\mathrm{CO}_{2}\right)$, and separate the carbon from the oxygen, retaining the former and retmoning the latter to the atmosphere. 'This carbon, combining with hydrogen and oxygen in the plant, is converted into starch, sugar, cellulose, ete., and thus enters into the structure of the plant.

'This proeess of absorbing and dreomposing earbonic acid gas takes plare only in smolight. In some moknown way, the influence of the rays of light is required to 
effect the change. For this reason a continuation of dark, rainy weather is injurious to the growth of most plants. In such weather they turn pale liom the alssence of coloring material, which requires the aid of smulight for its formation.

The air is admitted to the interior of a leaf through minute openings, of months, which generally exist in griat numbers. Upon an ordinary apple leaf there may be found as many as 100,000 of these openings.

Plants Purify the Air. - This absorption of carbonic acid and liberation of oxyen are of the greatest importance to animal life.

In the huns of men and other animals, oxygen from the air is contimully absorbed into the blood, and in place of it carbonic aciel gas passes from the lungs witl the breatl. An accumulation of this gas in the atmosphere womld soon lecome poisonous, but the danger is aroided, and the balance maintained, by the fact that all growing regetation is constantly withdrawing carbon and setting oxygen free. It is cstimated that an acre of forest trees will consume the carbonic acid produced by the breathing of fifteen men.

In this way regetahle and animal life mutually benefit cach other, each requiring and making use of that clement which is rejected by the other:

Do Plants Breathe? - While plants are taking in carbon and throwing ont oxygen, they are at the same time, though only to a slight extent, Hoing exactly the reverse,taking in oxygen and thowing ont carbonic acid. 'This is rery similar to the act of beathing in animals.

It would secm munceessary for the plant to take these two secmingly oplusite comrses, but they are for entirely different purposes. 
The process of breaking up the molecules of carbonic acid, and retaining the carbon, requires the aid of sme light, and is really a process of feeding, or uphilding the plant; hut the act of hreathing, or taking oxygen from the air, goes on continuonsly through the night, and is a process of oxilation or slow buning and destruction of the plant.

Absorption of Water. - But little water, if any, is absorbed by leares from the atmosphere. A drooping plant is quickly revived ly watering, or hy a shower of rain, not so much by absorling moisture through its leares as by the rapid passage of water into the stem and leaves throngh its loots.

Nitrogen from the Air, - While free nitrogen constitutes four fifths of all the air, it has generally been belicred that none of this is directly arailable for the use of plints. Recent investigations, howerer, show that certain varieties of plants are probably alıle, in some way, to make direct use of atmospheric nitrogen. This seems to be especially true of the family of plants called legminons, or pod-bearing plants. This family includes peas, beans, clover, lucern, ete.

Ammonia, which exists in small quantities in the atmosphere, is partly composed of nitrogen, and it is thonght the plant may olstain a little nitrogen by al)sorbing this ans through its foliage.

Roots. - The purpose of the root is to give the plant sulport, holding it firmly in position; to absorl nomrishment from the soil; ancl, in the case of biemnial plants, to store up a supply of food to support the plant the second year.

The radiele, or first root which deseends into the soil from the soed, soon sublivides into a number of small 
roots which extend in different directions, or sends out small branches on all sides.

Sonnetines the radicle continues to enlarge and grow downwar, forming what is called a tap-root, from which small fibels extend out into the soil. Clorer, Canada


The Roots of Plants.

$A$, Erigenin, with tuberous ront. B, Buttereups, with fibrous ronts. $r$, White Clover, with long tap-root and lranches.

thistles, and oak trees, for example, generally have such a tap-root. The root erops, beets, turnips, carrots, etc., are simply an enlargement of the tap-root, which serres to store up food intended for the support of the plant the following season.

The growth of roots consists mostly of lengthening hy building on additions at the extremities. In this way the difficulty of moving the root through its entire length is avoided, and every part, as soon as formed, is left in 
molistmbed contact with the soil. In some cases the tip of the root is provided with a kind of eap, or sitield, to protect it from injury as it forces its way through the soil.

The Number and Extent of Roots. - The proeess of sulbdividing and muliplying small roots goes on to a greater



Extremity of a Rootlet of Maple.

lleirs and ront-crip (a), magnified 50 dirmeters. extent than is enemerally supurosed. Rich soil in the vicinity of the loots of some plints hecomes completely filled with hair-like rootlets. Sometimes these are so small as to repuire the aid of a micioscope to defect them.

When a plant is pulled fiom the soil, these fibers are mostly broken off, only the larger roots remaining attached to the stem.

The entive length of all the roots of a plant is sometimes ahmost incredilile. In the case of barley, oats, and wheat, growing in rich, mellow soil, if has been formel that the total leneth of all the roots of one plant will amomt to from one hmodred to one humdred and fifty foet.

Cumber faromble eomditions, roots sometimes deseend to a errat deptle. In deep, mellow soil, the roots of most apricultural plants reach a depth of sereral fect. The routs of Indian com, which in commonsoil des not extend more than two or three foet hedow the surface, have been known to penctrate into the earth to a dopth of filteen fert. Clover roots have been triced to a denth of eight fect. 
Food from the Soil. - The only sulsstances that plants obtain from the atmosphere are carbon, small quantities of oxygen, and probably some nitrogen in the case of certain partienlar plants. All other nutritive substances, generally incheling nitrugen, must come from the soil.

A plant obtains these nourishing substanees from the soil throngh the moisture in which they have been dissolved. The moisture of the soil passes throngh the membranous corering of the root fibers, and thence upward into the plant, forming its sap or juice. Substances dissolved in this juice are thus able to find their way to all parts of the plant. In order to mulerstamel the rise and flow of sap, and the distribution of nutritive substances, it is necessary to consiler three principles of natural philosophy called diffusion, osmose, and capillary attraction.

1. Diffusion.--Diffusion is the term applied to the tendeney of different liquids, and solids dissolved in liquids, to become thoroughly mixed when placed together. If aleohol and water are placed together in the same vessel, they quickly mingle, so as to form a miform mixture. If a handful of salt is throwin into a pail of water, it is quickly dissolved, and evenly distributed, so that all parts are equally salted.

The same is true if sereral sulstances, as salt, sugar, and almm, are dissolsed in the same water. Wach is eprually distributed as if 100 other were present. These facts are due to the attraction of molecules of aleolol for those of water, and the attraction of molecules of watre for those of salt, sugar, ete. 'The fact that all the molecules of water have equal attraction for salt causes the salt to be equally distributed betweren them. If, in any ware, some of the salt eould be withdrawn from a portion Wra .lG. -5 
of the water, some of the remaining salt would immediately move forwand and fill the vacancy, so as to maintain an eynal distribution.

The diffusion of water and sulphuric acid may be secn by partially filling a glass jar or tube with water colored with bhe litmus, and pouring thromgle a tube, to the bottom, water containing a few droys of sulphuric acid. The effect of the acid woukd be to change the blue to red. Sulphuric acid is hearier than water, and would otherwise remain at the bottom; but accorching to the law of diffusion, it gradually mingles with the water abore until the color of the whole is changed to red.

2. Usmose. - The term osmose, from a Greek word which means to mush, is applied to the fact that substances which tend to mingle lỵ diffusion will pass through a porous partition semating them, and become as thoroughly mixed as if no partition were present. If a quantity of salt water and a quantity of swectened water are separated by a porons membrane, some salt will pass through the membrane one way, and some sugar the other way, until both are equally distributed through the whole.

The same is true of other substances dissolved in water, and of different liquids separated by a membranons partition.

This principle may be illustrated hy placing in a bladder, or some othor membrane, a small quantity of eolored alcohol, lowering this into a glass of water, and allowing it to remain until the water beeomes colored, showing that some of the aleohol laas passed thomegh the membrane into the water.

While the momblans, of other sulstance, must he poroms, the pores may be rely mimute. Water, and sub- 
stances dissolved in it, will find their way through a medium whose pores are too small to be seen, eren with the aid of a microseope.

3. Capillary Attraction - The attraction of solids and liquids for each other, in the case of solids which will not dissolve, is shown in the fact that the two adhere to each other when bronght in contact.

If the elge of a piece of glass is dipped into water, the water will rise a little distance upon the glass, and when it is withdrawn some moisture will remain upon it. If a small glass tube is placed in water, the attraction between

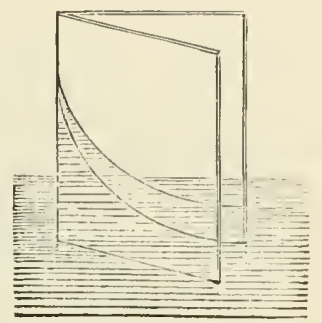

The Capillary Curve. the two will cause the water to rise in the tube. The smaller the tube, the higher the water will rise.

This prineiple of attraction between


solids and liquids, which causes a liquid to pass readily through the minute tubes or pores of a solid, even upward against the force of gravitation, is called capillary attraction, from a Latin word, capillus, which means a hair. The application is to the small, hair-like nature of the tubes thromgh which the principle works. A Direct Capillarity. familiar example of capillary attraction is the rise of oil in the wick of a lamp. 'The aftraction of cotton for oil canses the oil to pass rapidy upwarl through the pores of the wiek.

If one end of a towel is placed in a how of water, the water will gradually pass along the cotton or linen fibers until the whole towel is moistenced. 
Application of these Principles to Plant Growth. - These three principles all have an application in the passage of sulbstances into plants from the soil. Roots are covered with a kind of membranous coating. 'The moisture of the soil, massing through this coating, and upward into the plant, saturates the plant, or completely lills it with moisture, by the foree of eapillary attraction. The nutritire sulstances dissolved in the moisture likewise pass into the plant through its roots.

By the principle of diffusion, these substances tend to distribute themselves equally, not only through the moisture of the soil about the roots, but throughout the juice or sap of the plant.

The Absorbing Power of Roots. - The material of which the roots of plants are composed has a rery strong attraction for water. On this accomnt, the moisture of the soil is drawn upward throngh the roots into the stem and leares with considerable force. This pressure, by filling all parts of the plant, assists in keeping it in a frum, upright position. When the supply of moisture is cut off by dromght, or by serering the root, the plant withers and droopss.

It has been found that this force is sufficient to assist in the extension of luds and leaves in their growth. It is supposed to explain also the tall, slemder growth of erops in a wet srason. The upwarl pressure of the moisture, which is abundantly supplied to roots in such a season, is sufficient to forec the diflerent parts of the plant out of their normal rimonsions.

The Structure of Plants. - The roots, stems, and leares of plants, and in faret all verovable substances, are oriegi-

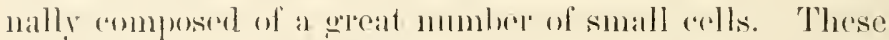
gencrally consist of little membranous resicles or hags, 
which are filled with liquid or solid matter. 'The cells of a potato contain little grains of starch, floating in a watery liquid. As the potato ripens, these grains become larger. When a ripe potato is boiled, the starch grains swell so as to burst the cells, and give the potato a " mealy" appearance. Stareh is obtaincel from potatoes by grinding to break the cells, and then washing out the starch.

Growth consists in the multiplication of these cells, either by dividing the old cell into sereral new ones, or by forming

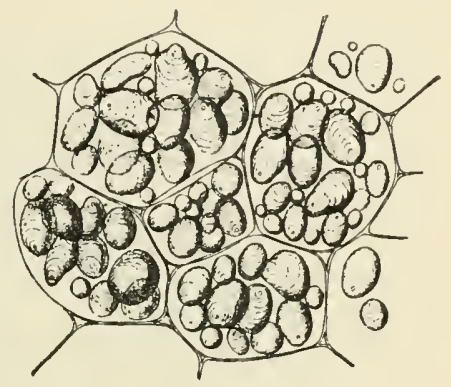

Cells from Potato Tuber.

(Shouing Starch Grains.) sereral new cells upon the outsile of the old one.

In the lower orders of plants there are some that consist of single cells, each new cell forming a separate plant. Others are composed of a number of these simple cells loosely attached to each other.

The mushroom that grows in a single night, ordinary mold, and the blight or smut that sometimes forms upon corn and grain, are examples of plants entirely composed of these simple, loose cells.

In the higher orders of plants, ripe fruit and some other soft, succulent parts, are also composed of simple cells, so loosely connected as to be easily scparated from une another.

In the more substantial parts of most plants, howerer, the cells ale not so soft and loose, but are firmly connected together, forming what is called regetalle tissuc.

Cells are of different shapes in the different varieties 
of plants, and often also in different parts of the same plant. In their simplest forms they are generally spherical, or globular. In the fiber of wood they are long and tapering, firmly joined together by their sides.

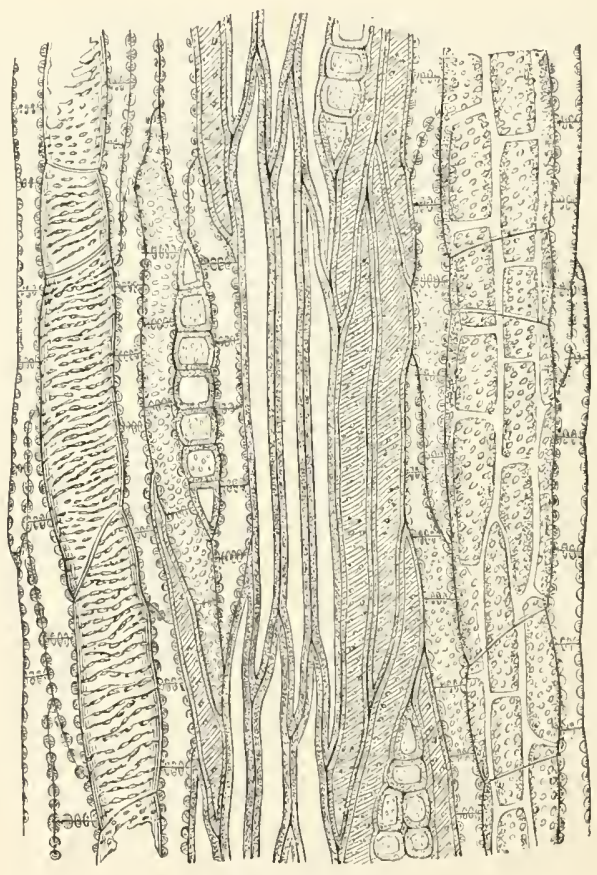

Section of Wood.

Ifngthurise slice of Wood from an Aitumflurs glamdulosa, or "Tree of Itearen," lighly magnified.

Sometimes the covering of the ends of these long cells is removed, so that ther ofern into each other, and form a continnous tube, throwg which the sap may flow more freely. Fibers of cotton and flax are simply long, single cells. 
The Flow of the Sap. - The sap is the moisture of the soil which hats prasised nuward, throngh the roots, into the plant. 'The plant is entirely filled, or saturated, with sap.

By the prineiple of osmose and the force of capillary attraction the sap moves partly along the tules formed by the union of long cells, and partly throngh the membranes from cell to cell, until every part of the plant is. filled.

When a plant has become saturated, there can be no more flow of sap until room has been made for more. 'The flow is kept up, partly by the growth or culargement of the plant, forming new cells which need to be filled with moisture, but mostly by the evaporation of the moisture or sap from the leares.

Leaves contain a great number of mimnte openings, particularly on the under side, which bring the air in immediate contact with the sap within. Throngh these openings the moisture of the sap is continually escaping into the air by eraporation.

In damp weather evaporation is slow, and hence the upward flow of sap is likewise slow; but in dry weather, and especially under the influenee of the warm sunlight, it goes on more rapidly.

'The quantity of water conveyed in this way into the atmosphere is very large, anoming during the season to many times the weiglit of the full-grown plant. Soril ocenpied with crops is thus dried much faster than that upon which no regetation is growing.

The abundant flow of sap from a maple in the spring is due to the fact that the tree is not only filled with sap, but this is placed under some pressure lyy the force of capillary attraction. As the tree contains no leaves at 
this season, there can be no eraporation to relieve the pressure. The sugar of the sap is ehemically formert in the tree, out of the starchy sulbstances stored during the previous antumm.

Nutrition. - The nutritive sulsstances which are designed to serve as food for plints, and are clissolved in the moisture of the suil, inchude a great variety.

Lach of these is needed in nearly all parts of the plant. The most of them, howerer, must undergo chemical changes before they are ready to be assimilated, or to enter into the structure of the plant. Some of them must first rise to the leaves to receive certain changes by contact with the atmosphere, and must then pass downward again to all points where they are required.

The sap of plants, like the blood of animals, furnishes a medium through which the elements of food may find their way to the points where they are needed, but the flow of sap is not at all similar to the circulation of the blood. The blood, in its circulation, actually carries substances to all parts of the borly, and deposits them at the points of destimation, but there is no such complete sisstem of conreyance in the sap. It is true that the clements of plint food are aided, in passing from the soil into the plant, by the upward mosement of the sap); but when once in the plant they must act independently of this morement, passing sidewise, downwarl, and in every other direction.

This is to be explained by the principles of diffusion and osmose.

As salt, when dissolved in water, will extend itself to all parts of the water, making its way through interrening membanes, so these mutritive sulstances find their way to every part of the plant. 
The Power of Selection. - A plant lias, in a certain sense, the power to make a selection of its food. While any substances dissolved in the moisture of the soil will natulatly find their way into the plant, onl! such of these as are neederl will be taken ul) and made use of.

Both the salp of timothy grass, and that of clorer, for instance, contain siliea. The timothy makes use of this to some extent, but clover, having little use for silica, permits it to remain in the sap.

It is believed that, in some cases, the roots of plants are able to produce chemical changes in some clements of soil, and eren of rocks, with which they are bonght in contact, withdrawing such parts as are
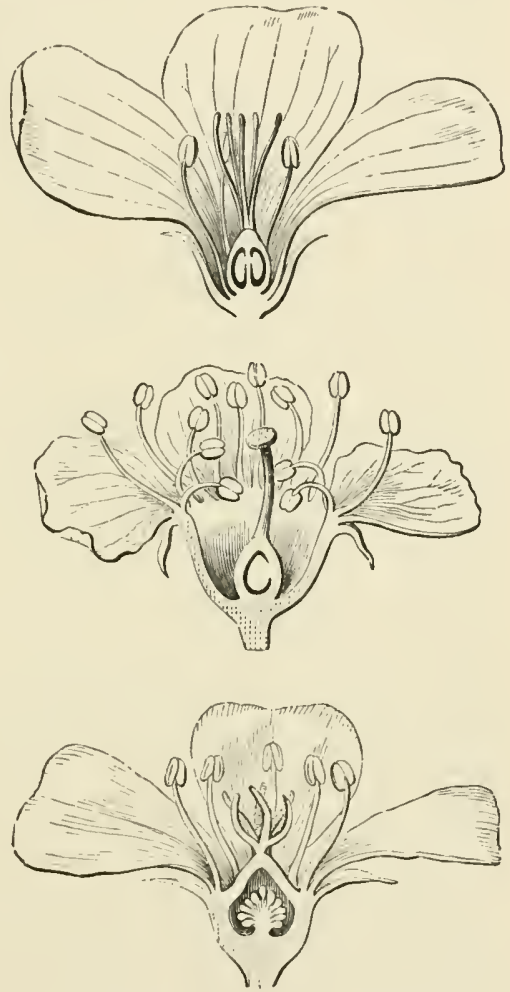

The Essential Parts of a Flower. required, and leaving the remainder in the soil.

Flowers and Seeds. - In a general sense, the aim and tendeney of plants is fmally to produee flowers, and then seeds, which, in their season, ale to spring up and produce similar plants, so that the variety may continue perpetually in existence. 
The essential prarts of a flower are the ecutral, or interior organs, by which the seets are formed. These are generally surromeded by floral envelopes, called the caly.r. and the corolla, whose individnal leares, the sepuls and petals, give the flower its heauty.

The eentral organs are of two kinds, called pistits and stamens.

The pistils contain germs from which seeds are formed, and the stamens produce a fine dust, generally of a yellow color, called pollen.

This pollen, falling upon the pistils, fertilizes them, and starts the formation of secels.

Csually both stamens and pistils grow ujon the same plant, and near each other in the same flower. In some varieties, however, the pistils are borne upon one plant and the stamens upon another. This is true of some varieties of strawberries, and of hop and hemp plants.

On account of this peculiarity, it is necessary, in cultivating these crops, to mix plints of both kinds.

Sometimes the pistils are borne npon one part of a plant, and the stamens upom another. An example of this is seen in Indian corn. The pollen produeed npon the tassel falls upon the silk, which is comnected with the pistils within the ear.

Pollen dust is produced lyy some plants in large quantities, and is earried long distances by the wind. 'This, falling upon different plants of the same species, causes a mixture.

By a transfer of pollen dust in this way, an almost endless rariety of some species of plants is obtained. A green variety of syuashes growing beside a yellow variety yields a variety partly green and partly yellow. Grains of pollen dust, earried ly the wind from one corn- 
field to another, will produce seattering kernels in the latter ficlu of the rariety contained in the former.

\section{QUESTIONS.}

What are plants? What are the two essential parts of a seel? What is the embryo? IIow long will seeds preserve their vitality? Why shonld new seeds be used for l, lanting? What is the effect of planting unripe seels? What is the effect of selecting the liest specimens of seeds for planting?

What are the three conlitions necessary for the growth of seeds? Ilow much moisture is most favorable? What is the effect of planting seeds in soil either too warm or too coll? What is the effect of planting seels too early in the sprinc? Why will seecls fail to grow where there is no air? Ender what circumstances is it best to plant seeds deeply? When is it better to corer them but lightly? What eauses weeds to spring wo after gromd has been plowed? Why have these weeds failed to grow hefore?

What are the three processes involved in germination? Why must the seed be filled with moistnre? Why is crain allowed to sprout in making malt? Why does spronting produce heat?

What are the radicle and the phumule? Why do they start from the seed in opposite directions? Which is more essential to the plant, the atmosphere or the soil? In what points do plants, in their growth, resemble animals?

Name the elementary substances that are essential to the growth of plants. What fool do plants obtain laresely from the atmosplese? Explain the process by which it is obtamerl. What has the smmlight to do with it? Why do plants become pale in dark weather? How do plants purify the air? Do they remove oxygen from the air? Do they purify the air in the night? Are they beneficial to the air in a dwelling-honse? Ilow are drooping plants revived by watering? Do plants obtain nitrogen from the air?

What are the purposes of roots? Name some plants which have taproots? By what method do roots grow? Ilow many roots have plants? How deep do they sometimes extend?

Name all the elements of forl that plauts ohtain from the atmosphere. Name those that they obtain from the soil. IIow do they 
obtain food from the soil? Explain the principle of diffusion. What canses sulstances to mingle and dissolve so realily? Explain osmose. How are liquids, and sulstances dissolve in them, alle to pass throm a membrane? To what fart is the terme ('ap)illary attraction applied? Why is it so named? Why will a whole towel become wet if one end is plaeed in water? Why will water rise higher in a very small tube than in a larger one?

How, according to these priuciples, do the substances of the soil priss into plants? What effect is produced upon plants by the attraction of their roots for water? Why does a plant droop when the soil becomes too dry?

Of what do the roots, stems, and leaves of plants consist? In what way is growth proluced? Name some plants composed of loose cells. What is vegetable tissue? What is the form of cells in different plants?

Explain how moisture reaches all parts of the plant? What two eauses tend to keep up a continuous $\mathrm{fl} / \mathrm{w}$ of sap? How does the moisture of sap escape into the atmosphere? Why does sap flow slowly in clamp weather? Explain the carse of the abundant flow of sap from the maple in the spring? Why does the flow cease as soon as the leaves betrin to grow? Does the flow of sap resemble the circulation of the blood of animals?

In what direction do the nutritive substances move within the plant? What causes them to move? ('an plants chowse their food?

What is the natural purpose of the growth of plants? Name the different parts of a flower. Explain the purpose of the pistils and the stamens. Name some plants that have only one of these upon a single plant. Name some that have the two upon different parts of the same plant. Iow are many different varieties of the same species of plants obtained? Why will not preas alld beans mix and prol ace uew varieties? 


\section{CHAP'TER V.}

\section{FERTILIZERS.}

Fertile Soil. - The fertility of soil depends upon its ability to supply plants with all the elements of food which they require. No one of the elementary substances whieh have been enumerated as always found in the composition of a plant ean be dispensed with.

As an animal cannot live or thrive without a proper supply of the ordinary elements of food, so a plant requires a regular supply of these varions elements from the soil. A plant poorly supplied with potash or nitrogen, for instance, would produce only a sickly growth, and if entirely deprived of these, or of any other essential element, would die.

Fertile soil, therefore, must contain not only large quantities of plant food, but sufficient quantities of every kind of food which plants obtain from the soil to supply the wants of the crop.

So, too, soil must not only contain these elements, but they must be in a form in which plants ean make use of them. An aere of soil may eontain many tons of nitrogen or phosphorie acid, and yet may be totally unfit to produce a erop, becanse these cannot be eonverted into suitahle forms fast enongh to supuly the amount of food required.

The following list gives the pereentage of different substances which may exist in ordinary dry, fertile suils. 


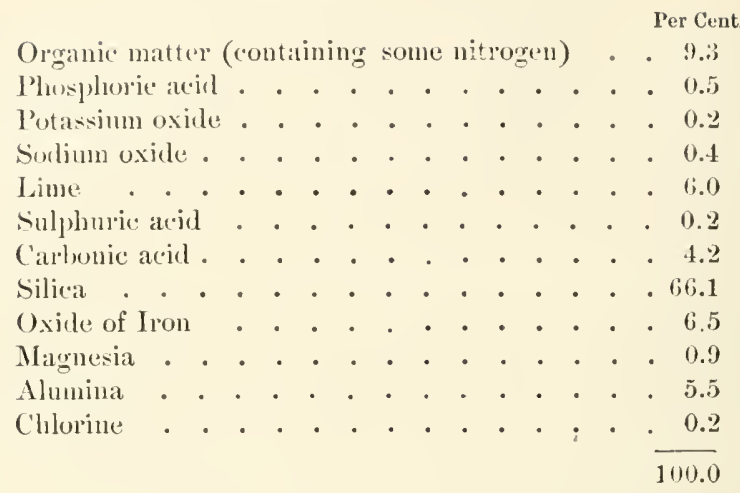

The pereentage of many of these seems small, but it amounts to a large quantity per acre. One tenth of one per cent. of the dry soil of an acre would generally amount to two or three tous.

The quantity of many of these substances required by erops is so small that they are practically inexlaustible. Of those substances which erops require in larger quantities there would be enough to last many years, provided they conld be changed and made arailable as fast as required.

'ithe ordinary erop of wheat raised upon an aere might require, among other elements, fifteen pounds of phosphoric acid and eighteen pounds of potash. If the entire amount of these substances maturally contained in good soil comld be made nseful as fast as needed, there would lic no lack for many yours.

The Effest of Agriculture. - In a state of nature fertility is maturally maintained. Plants that grow upon the soil die and decay moon it. 'T'mos, those clements of fertility which have heen withlrawn from the soil hy plants in their growth are returned to it by their death. 
In the process of agriculture, by remoring crops we take away a duintity of these elenents, year by year. If this is contimed, and nothing is returneil to the soil, in the eonse of time it becomes imporerished. The supply of plant food is exhausted, and not enough is changed to an arailable form, year by year, to produce a erop.

Land that is "rom out" in this way may still eontain large quantities of some clements of fertility, being deficient only in a few. By supplying the latter we may still keep up the fertility of the land for many year's. If, for instance, the soil of a eertain field contains enough avaliable nitrogen to support a crop two years, enongh phosphoric acid and potash for five years, enough lime for ten years, and enough of other substanees for a longer period, it is evident that after two years we must supply nitrogen, after five years phosphorie acid and potash, and so on, unless some of these elements have been lost in the mean time, or some have been added by natural causes.

The Soil a Storehouse of Plant Food. - Ordinary soil appears to be composed of simple, inactire, unchanging substances, but in reality it is like a rast ehemical laboratory, in which plant food is continnally prepared, and either furnished immediately to the plant or kept in store for the future.

A portion of the rocky or mineral parts of soil contain sulnstances which, when they have been changed by whemical action, beeome food for plints. Among the most fertile kinds of soil are those which have been produred ly the ermmbling and decay of granite and limestone. Vegetable mold, which results from the decay of plants and leaves, and which is found to a certain ex. 
tent in nearly all varieties of soil, is larocly composed of the elements of plant food, which are gradually rendered arailable, year after year.

Chemical action, or the formation of plant food in these substances, is checked by cold weather, but goes on contimnonsly in the summer season. It is aliked by a proper supply of moisture in the soil, by the oxygen and carbonic acil of the atmosphere, and by the small quantities of ammonia and nitric acid which are bronght to the soil in rain.

An application of fertilizers to the soil not only directly supplies the elements of plant food, but is also useful in furnishing substances which are needed to unite chemically with other substances already contained in the soil, in order that the latter may become serviceable.

When roots of growing plants are present, these nutritive substances are immediately absorber, so far as thry are needed. If formed faster than needed, the surplus is either retained for future use, ol is washed away by rains and wasterl. Some rarieties of soil, particularly those containing clay or regetable molel, are able to retain laroe quantities of these elements for a long time, but from loose, gravelly, or sandy soil they are casily washed away.

The Elements Needed in Fertilizers. $-\Lambda$ majority of the elements of fertility are contained in most soils in sufficient quantities to last many years. Those which generally fail the soonest, and which we must aim to supply in fertilizers, are nitroysu, phespleoric acid, and potash.

Some prenliar soils may he wanting in some other substance, as sulphur or lime; but when soils begin to 
be mproductive, the lack of one or all of the three elements mentioned is almost miversal.

Plants require larger quantities of these elements than of any other, and hence they fail the somest.

Nitrogen. - Nitrogen is an element both essential to plants and difieult to obtain. While the air contains an abundance of it, but few plants can make use of it from that source. It is not generally arailable to the plant in its free state, but in combination with other elements.

'There are two compoumds of nitrogen in which it is believed to be mostly serviceable to plants: they are nitric acid and ammonia.

The plant seems to obtain most of its nitrogen by taking up through its roots either of these substances, or compomels formed by the chemical action of these upon other substances.

1. Nitric Acid $\left(\mathrm{HNO}_{3}\right)$. - Nitric acid is formed in the soil by the decay of organic matter. $A$ small quantity of it also exists in the atmosphere, some of which arises from the decay of organic substances, and some is believed to be produced out of the free nitrogen and oxygen of the air by electric currents passing through it.

This acid, either formed in the soil or washed into it from the atmosphere, enters the roots of the plant, either directly, or in the form of salts, ealled nitrates, produced by its union with alkaline sulstances.

2. Ammonia $\left(\mathrm{NH}_{3}\right)$. - Ammonia is also produced by the decomposition of animal and regetable matter, from which, unless absorbed and retained by other substances, it easily escapes into the atmospliere. It is rery soluble in water, and is alssorbed by various substances, as peat Wixs. $\Lambda$ gris. -6 
and decaying regetable matter, clay, and other soils. Charcoal will albsorly ninety times its own bulk of ammonia gas.

Ammonia is therefore widely diffused, thongh in small quantities, in the atmosphere, in the land, and in the water of the earth. It realily combines with acids, and in the atmosphlere is not generally found in a free state, but combined with carbonic acid, forming earbonate of ammonia. 'This carbonate is dissolved in the moisture of the atmosphere, and brought to the carth, where, together with the ammonia already contained in the soil, it adds to the supply of nitrogenous plant food.

Only a part of the nitrogen repuired for producing farm crops is furmished in the natural supply of nitrie acid and ammonia. 'The farmer atds to this suplyly hy fumishing fertilizers which either contain these sul)stances or their compounds, or which will produce them in the soil by decay and chemieal changes.

Nitrification. - The vegetable matter which exists in ordinary soil in the form of decaying grass, leares, roots, or stable manme, contains nitrogen combined with earbon. In this condition it is not arailable as plant food. By a peruliar proeess called nitrification the nitrogen is sepurated and conrerted into nitric acid. This acid again combines with bases in the soil and forms nitrates, as nitrate of lime, nitrate of sorla, or nitrate of potash, and these are easily dissolved and readily alsorbed by the loots of plants. 'They are also casily washed away from the soil and lost when there are no plant roots ready to take them $m$ ).

The process of nitrification is brought about by the growth of a minute plant. 'This plant thrives in warm, moist soil, which is sufficiently porons to adnit air, and 
which contains some alkaline substance. During the warm summer months nitrates are continnously formed in this way to support plants while they are growing most vigorously. Yomng plants sometimes snffer from the want of nitrogen in the early spring, before the soil becomes sufficiently warm for the formation of nitrates.

Phosphoric Acid $\left(\mathrm{P}_{2} \mathrm{O}_{5}\right)$. - Phosphoric acid, a combination of phosphorus and oxygen, is not found free, but in combination with potash, soda, lime, ete.

It is very largely a plant foot, and is especially necessary for the proper ripening of plants and the formation of seeds. Its most common form is that of phosplhate of lime ( $\left(\mathrm{aOCl}_{2} \mathrm{O}_{5}\right)$. In this form it constitutes about one half the substance of the bones of animals, which are largely used in preparing this element of fertilizers.

Potash $\left(K_{2} \theta\right)$. - Potash is also an important element of fertility, which does not exist in ordinary soil in sufficient quantity to support a continuous succession of crops.

It is generally obtained and used in the form of salts of potash, as earbonate of potash $\left(\mathrm{K}_{2} \mathrm{CO}_{3}\right)$, chloride of potash ( $\mathrm{KCl}$ ), etc. Carbonate of potash is the important part of wood ashes. "New" land is generally well supplied with potash in the ashes resulting from the burning of trees and brusls.

Artificial Fertilizers.-- 'To supply nitrogen, phosplonic acid, and potash to the soil, as well as certain other elements which are sometimes needed, substances are either mannfactured, or are obtained in a natural state in different parts of the work. To distinguish these from ordinary farm mannre, which is the most common 
and natural fertilizer for the farmer, they are called artificinl fertilizers.

'The materials for them are obtained from a rariety of sonrees, some of the more eommon of which are als follows: -

Sources of Nitrogen. - 1. Nitrate of sorlal, or Chili saltpeter, is extensively obtained 11 a natural state from some garts of fonth America.

2. Sulphate of ammonia is obtained for a fertilizer from "gas liquor," or the water in which illuminating gas has been washed. The ammonia which the liquid contains is obtained by trating it with sulphuric aciel, with which the ammonia combines.

3. Fish seralp, meat scrap, dried bloorl, and all forms of anmal refuse, are rich in nitrogen, and are generally used for manufacturing fertilizers.

Sources of Phosphoric Acid.-1. Bones are largely composed of phospluate of lime, which is converted into an arailable form, called superphospleate, by an application of sulphuric acid. Crushed and gromel hones are also used directly as fertilizers, but rield their phosphoric acid more slowly. Bone-ash, produced by burning bones until they ermmble easily, is less valuable than gromel bones, as the proeess of hurning remores from the bones what nitrogen they contain.

2. Bonc-black, or charred bone, is used at sugar refincries for cleansing sugar. After it becomes nscless for this junpose it is treated with sulphuric acid to convert its elements into a soluble form, and is then sold as a fertilizer.

3. Nineral deposits are found at various points of the earth containing a lare perentage of phosphate of lime. 'Their origin is suppreserl to have been an accumulation of 
the bones of animals at some prion in the ancient history of the earth. Many of these deposits are nsed an at source of phosphoric acjd for fertilizers. Those userl in this eomntry are obtained from sonth Carolina, in what is called "Sonth Carolina rock," and from Canada, in the form of a green mineral, called apatite.

4. By a proecess of manufacturing steel there is formed a waste product, or slag, which contains phosphorie acid. This is sometimes used in preparing fertilizers.

Sources of Potash. - 1. Wood ashes contain to some extent all the mineral or inorganie elements of plant food, but are particularly rich in carbonate of potash. They have been nsed as fertilizers since very ancient times. Until quite recently they have served as the only source of potash for artificial fertilizers.

2. In the mines of Germany, potasl is oltained in the form of salts of sereral varieties. These are known as "German potash salts." Chloride of potash, commonly called "muriate" of potash, obtained from this source, is largely used in this country for fertilizing purposes.

Guano. - Certain islands off the western coast of Sonth Ameriea have for centuries been the haunt of comtless numbers of sea birds. The droppings of these birds constitnte grano. It has accumulated in some places to the depth of from twenty to fifty feet. The general absence of rain in those regions has prevented the valuable elements from being washed away. Large quantities of this guano are shipped to different parts of the world, and are either applied directly to the soil, or used in prefraring other commereial fertilizers.

Prepared Fertilizers. - The various sulstanees cummerated may be used singly as fertilizers, or in combination. 
The most of them need to muleroo chemical treatment to render their elements avalable. 'The work of preparing and mixing is mostly done at large factories, from which the ordinary commercial fertilizers are shipped and sold to farmers in all parts of the country.

The aim in preparing these is to pooluce a mixture containing the three elements, nitrogen, phosphoric acid, and potash, in the proportions in which they are needed for arerage soils and crops.

'To meet the wants of particular erops, so far as they are understood, special fortilizer's are sometimes prepared and sold for each corp, containing the three elements in rarying proportions.

In addition to the substances mentioned, which furnish the three most essential clements of fortilizers, there are certain others which serve some pmpose, either directly or indirectly, in inproving the fertility of the soil.

Lime (CaO). - Lime, or oxide of calcimn, is obtained in large quantities, in various localitics, from " limestone quaries." In its natural state it is fomnd combined with carbonic acid, for which it has a strong attraction, forming ealcium carbonate $\left(\mathrm{CaCO}_{3}\right)$.

Calcimm oxide, or quicklime, is obtained by heating the calcinm carbonate mith the carbonic acid is driven off.

Quicklime has a strong attraction for hoth carbonic acid and water. When exposed to the atmosphere, it slowly alsorbs both these substances, forming air-slaked lime. If brought in contact with water, it unites with it so rapidly as to cause great heat, producing calcium hydrate $\left(\mathrm{CaO}_{2} \mathrm{II}_{2}\right)$.

Lime is bmoficial to soil in rarions ways:-

1. It serves directly as plant food. All plants recuire a small quantity. 
2. It combines with, and decomposes, regetable sulbstances, and other elements of the soil, preparing them for plant food.

3. In a general way, it has a beneficial effect upon varions kinds of soil, rendering them better adapted for agricultural purposes.

It renders heary, clayey soil more loose and mellow, and sandy soil more compact, so that it will retain more moisture. It neutralizes the injurious acids of cold, peaty soil, and loosens it for the admission of warm air.

Many varieties of soil already contain lime in abmndance, lout where it is deficient, its application is often of great benefit.

Marl. - Marl is composed of carbomate of lime mixed with other substances, as clayey or sandy soil. It sometimes contains some nitrogen and phosphoric aeid. The low places where it is fomd are smpposed to be the beds of ancient lakes which have dried np. 'The deposit has been formed hy the acemulation of shell-fish at the bottom of these lakes, through long periods of the ancient - world. Marl is used as a fertilizer in regions near these heds, where the expense of transportation is not too great.

Gypsum. - Gypsum, or land plaster, is prodnced by a union of lime and sulphuric acid, giving calcium sulphate and water $\left(\mathrm{CaSO}_{4}+\mathrm{H}_{2} \mathrm{O}\right)$.

By heating gylusum, the water is driven off, learing the calcium sulphate, or plaster of Paris.

It is fomd in nature, in some loealities, and is used as a fertilizer where lime and sulphur are needed. It is especially heneficial to elover, and other legmminous erops.

Salt ( $\mathrm{NaCl}$ ). - Common salt is composed of solim 
and chlorine. As plants contain both these elements, in small quantities, salt is of some value as a fertilizer in soils where they are lacking. It is also of some benefit in preparing plant food by exerting chemical action upon other substances. It must be used with caution, as in too large quantities it is fatal to regetation.

An intelligent and economical use of fertilizers requires a knowledge of four points :-

1. What the Fertilizer Contains. - Is the composition of sulistances used as fertilizers is determined by chemical analysis, this is beyond the power of the ordinary farmer. 'The goremment generally affords protection against the sale of worthless compounds by requiring that the eomposition of the substance exposed for sale slabl be printed npon the package, and by providing for chemical tests of the goods as they are found in the market.

2. What the Soil Requires. - The comprosition and condition of soil in different localitio's, and at different times, are so varied, that no general rule for the use of fertilizers can be safely followed.

One ficld may require nitrogen, while another may be wcll smpplied with this, lunt may lack phosphoric acid, or potash, or both. The use of a fertilizer in each field, containing an arerage quantity of each element, might be a wasteful practice.

'The only method arailable to farmers for determining what their soil needs is to conduct "field experiments," applying different fertilizers to different sections, and noting the results. For such a purpose, the three elements may be obtained singly in "chemicals."

Nitrogen, for instance, may br obtained in sulphate of ammonia or nitrate of suda; phosphoric acid, in gromel 
bones or dissolved bone-hlack; and potash, in murate of potash or sulphate of potash.

3. What the Crop Needs. - The different crops rary considerably in the relative quantity of the three elements needed. It is important that each be supplied with a fertilizer suited to its especial wants.

By a chemieal analysis of different crops, we may learn in what proportion the different elements of food are required in their formation, and so may obtain some idea of the proportion in which these elements should be applied to the soil.

4. The Amount Required per Acre - Economy in raising erops, as in raising animals, requires that they shall receive all the foud they can consume and properly assimilate. No crop can reach and thus ntilize all the food present in the soil; henee, more should be furnished than enongh to corer the wants of a single erop. At the same time, a large smrplus would involve waste, except in soils which are alle to retain it for future crops.

Methods of Applying Fertilizers. - The valuable elements of most prepared fertilizer's are largely soluble in water: and, as the tendency of rain is to wash these parts downward, they should generally be mixed with the surface soil.

These fertilizers are usually so concentrated as to injure or destroy seeds and roots when brought into immediate contact with them. On this account, care should be taken, in planting, to place some soil between them snd the sprouting seed.

It is wiser to place them above, rather than beneath the seed, so that the young roots may not he injured, and so that their elements may be gradually washed upon the roots as needed. 
Is the roots of plants are rapidy extended to considerable distances in all directions, it is better, where much fertilizing material is to be used, to distribute most of it erenly through the soil, and apply but little to the hill or drill.

Farm Manure. - The ehief somree of fertility, and that upon which famers mainly depend, is stable manure. As it is generally impossible to raise good crops without supplying some kind of fertilizer to serve as plant food, the manure of the farm becomes a matter of the greatest importance. 'The size and nature of the manme heap' often determine the profits of the farm. It is sometimes called the farmer's "gold mine."

Sincess in agrienlture depends vory lareoly mon an undirstanding of the nature, the means of preserving. and the proper methods of applying farm mamme.

Its Nature. - It differs from the ordinary commereial fertilizers in three respects:-

1. It eontains all the elements of food required by plants. As farm animals live mpon the crops or plants of the farm, it is evident that the manme will contain the substances which eome from these plants, and of which they are composed, less so much as the animal has assimilated, and converted into flesh, bones, wool, milk, ete., and the carbon which has escaped with the breath.

Only a small part of the elements of food are thus assimilated and retained by the animal in digestion. The amount will depend upon the nature of the animat. In the case of young, wowing animals, cows giving milk, or sheep producing large quantities of wool, the proportion retained will he greater than in the rase of mature animals yielding no increase. It may be stated, 
as an average, that from eight to nine tentlis of the mammrial elements of the food of animals exists in the manure.

As the elements of manure are the same as the elements of plants, it is evident that the mamme is suited for the growth of other plants, in turn, provided it is all preserved and returned to the soil withont loss or waste, and provided sufficient fertilizing material is added to take the place of the part retained by the animal.

2. It is less concentrated. A ton of average manure contains only about 25 pounds of plant food. The remaining 1,975 pounds can be of 10 direct serrice as food for erops. This renders it more expensive to handle, which is sometimes a serions ohjection where it must be conveyed a long distance.

The bulky nature of manure, however, gives it ecrtain adrantages. It is of great benefit to heary soils, by making them mellow and porous for the admission of air, rendering them drier in a wet season, and at the same time enabling them to retain moisture in a time of drought.

The lack of some mechanical "divisor," such as is furnished in common manure, is a serious objection to continuons farming with artificial fertilizers alone. It often becomes necessary to plow in a crop of elover, or some other bulky substance, in order to supply this want. Without some treatment of this kind, soils after a time are liable to become solid and compact, and may suffer from the slightest dronght.

3. It yields its smplies of plant food more slowly. A large proportion of the valuable elements of ordinary commereial fertilizers is usually soluble, and immediately arailable to plants. Probably from one half to 
three formths of the value of these fertilizers may be obtained in the first crop after they are applied.

In stable manure, only a small proportion of these elements is soluble and available at first. Not more than one fourth of its value is ordinarily obtained the first season. 'The pemainder must wait for chemical action slowly to resluce it to avaliable forms.

The Care of Manure. - The value to be derived from stable manme depents largely mpon the care excroised in preserving it.

Prohably nearly one half the valur of manne thronghont the eomntry is lost. Fome loss is, of comrse, malroidable, but it may be largely prevented hy proper care.

'There are three general sources of loss :-

1. Fermentation. - Fermentation is a proeess of deeay, or decomposition, which organic substances undergo when brought in contact with moderately warn air. The chemical proeess eonsists jartly of oxidation, producing heat. On this account, it is sometimes called heutiny.

Some kinds of manure ferment much more readily and rapidly than others.

Sometimes, if the process is allowed to continue m. checked, it will give to mamure the appearance of having heen partially burned, leaving only a light, msubstantial mass helind. It is then said to he "fire-fanged."

By fermentation the most valualile elements of manme are converted into gases, and tend to escape into the atmosphere. Nitrogen is eomrerted into ammonia, and earhon into earbonic acid uas. 'The loss of the former is of far greater importance than that of the latter, sinee calbon, whirh plants obtain so lalowly from the atmosphere, is of less value in mamme. 
When the fermentation is going on rapidly, ammonia is sometimes formed su fist ats to produce a strong, pumgent odor. We may detormine whether it is escaping to some extent by suspending wrer the manure heap a piece of litmus paper in which the blue color has been changed to red by dipping it in some acid. If there is any ammonia escaping, it will gradually restore the color from red to bluc.

Slight fermentation would do no harm, and in fact may be of some advantage in converting the elements of manure into arailable forms, provided there are other substances fresent ready to mite with the gases, and retain them as soon as they are formed, so as to present their escape. It is in this way sometimes desirable for special purposcs, as in compost heaps. Generally, however, it is to be aroided, since any adrantages gained by the process are orerbalanced ly the loss of escaping galses.

The ordinary methods of ehecking fermentation are:-

(1.) By mixing the manure of different animals. Some kinds of manure are slow to ferment. When these are mixed with other kinds, the fermentation of the mass is cheeked.

(2.) By keeping the manure heap wet. A certain amomit of moisture aids fermentation, but an excess checks it. It is therefore of some adrantage to keep the heap as moist as possible without eansing loss by drainage.

(3.) By keeping the heap trodden down, so as to exclude the air. As the process requires the mesence of the atmosphere, it is evident that it may be largely prevented by exchuling the air as much as possible.

For this reason it is often of great serrice to allow 
pios, or other amimals, to run upon the manure heap, so as to keep it in a compact condition.

2. The Esscupe of Liquirls. - The liquid parts of mamure contain more than one half their value. It is important that some dry, spongy substance, as straw, leaves, dried muck, or dry soil, be used to alssorls and retain them. The nitrogen which serves to form anmonia by fermentation, is largely contained in the linuids, and the presence of these substances in some measure prevents the escape of ammonia, by combining with it or alsorbing it.

The same purpose may be more fully accomplished by applying to the lingids sulphuric acid, or grosmm, which is partly composed of that acid.

3. Exposure to Rain. - The liquid parts contained in mamme, and held hy alisorlents, are readily washed out by heary lains. Both ammonia and nitrie acid, the two available forms of nitrogen, are largely lost in this way, as well as some other elements.

When mamme is piled in heaps upon land which is to be cultivated, it is true that these elements are washed into the soil. 'This, howerer, incolves waste, as the small plots beneath the heaps are too much orerstocked with these vahable substances to be able to render any arleculate returus in the erops.

To prevent waste by washing, mamme shonld be kept muder eorer; or, if exposed, shomld be so protected as to receive only a small amount of rain, which would ro no) liarm.

Methods of Applying Manure. - Whaterer particular methods are employed in applying manure to the soil, there are two general principles that should always be borne in mind : 一

1. It shomld be applied as soon as possible. All 
waste, either by fermenting or washing from the heap, is arvided as soon as the manme is seattered upon or incorporated with the soil. By piling it in heaps, and allowing it to ferment, it may be rendered more suitable for the immediate wants of certain erops, but this is at the expense of some of its value. When applied without such fermentation, it may be slow to yield its elements the first scason, but these are preserved for future years.

2. It should be rendered as fine as possible, and thoroughly mixed with the soil. Those parts which are soluble at first may be washed out, and distributed ereuly enough for practical purposes, under any methods; but in older to secure the benefit of the mechanical effect of mixing the solid parts with the soil, and the chenical effect produced by these upon the soil in decomposition, it should in some way be finely divided, and thoronghly mixed with the soil, so as to bring its particles into contact with as many particles of the soil as possible.

Swamp Muck. - Muck or peat beds are numerous in low, wet places, throughout a large portion of the country. Muck consists of partially decayed regetable matter, which lias accumulated through past ages. It is of consirlerable value as a fertilizer. It is especially rich in nitrogen, samples often yielding from one to three per cent. of it.

'The fertilizing elements of muck, howerer, are in the form of certain aciis, or insoluble compounds, which are not, in their natural state, arailable to plants. Before it ean be of much serviee it must be treated with some alkaline substance, so that its aeids may be neutralized and its elements converted into arailable forms.

This may be accomplished in three ways:-

1. By long contimued exposure to the air. If taken from its bed and exposed to the air, it will be gradually 
but very slowly changed by contact with ammonia and other substances which exist in small quantities in the atmosphere. This entrse is not rery practicable, as sereral yeal's are required to effoct a complete change.

2. By mixing it with some alkiline sillostance, as lime, wood ashes, or some of the salts of potash. If mited in a compost with a small quantity of these substances, the desired change is soon olutained.

3. By mixing it with stable manme. 'This is a very profitable method of treating it. A twofold purpose is accomplished: the manure fmonishes the alkaline elements for the muck, and the muck retains those rlements of the manure which would oflerwise eseape into the air by fermentation. For this pmpose, me part of manure is resarded as sufficicnt for three parts of muek.

Muck as an Absorbent. - Muck, like ordinary regotalsle mold, possesses the property of alsombing latere quantities of water. As taken from the swamp, two thirds or three fourths of its wright is water. In drying, its loulk is greatly redncel. This property ponders dried muck an excellent alsorbent for the liquids of the stable. These liquirls are exactly suited to produce the proper changes in the muck.

Muck may be profitably applied to land not well supplied with hmmus, or vegotable mold.

The Value of Muck. - The elements of which ordinary mure is composent give it a nominal value about equal to that of stable mamure. Its real value is reduced, of comrse, by the labor and expense of proenring, composting, ete.

There is a wide difforemee in the quality of muck from different localities, depending upon the nature of the substances out of which it has becen formed, 
In some cases it contains a large quantity of ordinary soil, or other comparatively worthless matter. Some simples yield three or four times as much nitrogen as others. Before much expense is incurred in procuring muck from any particular bed, some idlea of its value should be obtained, either by chemieal analysis or some other experiment.

Some idea may be oltained of the proportional amount of worthless sand, or other mincral matter which the muck contains, by placing a small quantity in a tube or glass of water, shaking the glass thoroughly, and, after allowing it to stand for some time, noting the quantity of mineral substances which settle to the bottom.

\section{QUESTIONS.}

What is fertile soil? Name the elements neessary to make soil fertile? Would a soil containing no sulphur le fertile? Would seraps of leather, which are largely composed of nitrogen, add to the pres'nt fertility of soil? In what way is the fertility of the soil naturally maintainerl? What is the effert of raising crops?

What processes are going on in the soil? Do rocks furnish food for plants? What effeet has cold weather upon the elemical processes in the soil? What is the effert of the atmosphere? Ilow do fertilizers aid the chemical action? What becomes of the fertilizing substances formed in the soil? Why is it more important that loose soil shonld be always oceupied with regetation than elayey or mucky soil?

What elements are most generally lacking as soil becomes impoverished? Why is nitrogen expensive as a fertilizer? In what forms does it generally become fool for plants? Where is nitric acid fornd, and how is it produeed? How is ammonia formed? Where is it to be found in nature? In what way does the farmer add to the natural supply of nitric acid and ammonia?

What is meant by nitrification? IIow is the process brought alout? What ennditions are necessary? Why is the supply of nitrogen smaller in the early spring than in summer?

Wrss. Agr. -7 
Of what is phosphorice acicl composed? In what forms is it to $x^{2}$ fomm? Of what special nee is it to plants? Why is new lamd erenerally well snpplied with potash?

What do antificial fertilizers usmally contain? From what soures is nitrogen obtained for these fortilizers"? Name the different sourees of phosphoric acicl. Ilow is potash obtained?

What is guano? What other sulstince's are sometimes useful as fertilizers hesiles those mentioned! In what form is lime found? How is ruicklime proulued!" What is air-slaked lime? In what three wa!s does lime benefit suil?

What is marl? Give the history of its formation. (Of what use is it as a fertilizer" "

What is gypsum?. How does it benefit soil? Is salt a fortilizer, and low?

What points shonld be umlerstood in order to make a proper use of fertilizers? How may farmers learn what fertilizers contain? llow ean they learn what the soil recpuires? Why does one crop need a different fertilizer from another? Why must soil eontain nore fertilizing material than the cop uses? Would the surplus be: wasted in a clayey soil?

Why should elemical fertilizers be placed near the surface of the soil? Why should they not be allowed to come in contact with seeds and roots? Why shonld hut little be used in the hill?

Why is the mamure heap sometimes ealled the farmer's gold mine? In what three respeets does stable manure differ from commercial fertilizers? Why is it a emmplote fertilizer?

What part of the elements of plants is retained in digestion? Of what advantage is the bulky mature of manure? How does it render land more moist in al dry time? What part of the value of manure may be olitained in the first erop? What are the three sources of loss to which stable manure is subject?

What is fermentation? Ilow is the leat produced? What substanres are lost by fermentation? Why is fermentation desirable in a compust heap? In what ways may it be partly prevented?

What is the chief alvantace of allowing pigs to rmu upon the manure heap? What is the value of the liquill parts of mimure? What element gives them their chief value? What are the lenefits of using alsorbents in the stable?

of what special luefit is grysum in mannw? IIow ran there be any 
waste from manure heaps piled upon cultivated land? Can there be any loss to manure while it is frozen? What two general points should be observed in the use of manure? Why should it he applied to the land as soon as possible? What are the advantages of renclering it fine?

In what does the chief value of swamp muck consist? Why is it of little value when first obtainerl? In what three ways may the neeessary changes in its nature be lronght abont? Why are alkaline substances needed? Why is the practice of mixing it with stable manure especially profitable? Why is it a good absorbent? Give some idea of the value of muck. 


\title{
CHAP'TER VI.
}

\author{
CLLTIVATION.
}

Cultivation, or the mechanical handling of soil for the benefit of cropss, includes a large part of the lilhor of farming.

An mderstanding of the reasons for the different processes cubraced in the tillage of the soil, and of the benefits to be derived from them, is essential to sueess in agrieulture.

Purposes. - The pimrposes of cultivation may be classified as follows :-

1. To lreak up the soil, or make it "mellow"," so that the roots of plants may easily penstrate it.

The roots of a few varicties of plants are very hard and firm.

Some are provided with a sharp point at the tip, so that they are able to penetrate hard sulsstanees. Quitelsgrass loots will sometimes grow entirely through a potato. But the roots of most agrieultural plants are more delicate, and make their way with diffieulty through harel soil.

In poorly eultivated soil, filled with hard limpse, roots are fomm to ocenpy the mellow portions, avoiding the lumps. To leave the soil in a lumpy condition is therefore to reduce the extent of the feeding gromend of the plant. 
The depth to which roots penetrate is largely determined by the depth to which the soil is stimed in cultivation.

2. To admit air to the roots.

Most agricultural plants of temperate climates will live and thrive only in soil which is sufficiently porous to admit air.

Experiments show that the roots of such plints, as well as the foliage, require the presence of free oxygen. The plants either die, or proruce a feeble, sickly growth, in compact soil, or in soil continuously saturated with water.

There are exceptions, as in case of the cranberry plant and rice, which thrive best in soil completely covered with water during a portion of the year.

3. To hasten the decomposition of the soil, and the formation of plant food.

The chemical processes in the soil are hastened by exposure to the air. They are partly depenrlent upon a suplly of oxyen, carbonic acid, etc., from the atmosphere. By loosening the soil, so as to admit air, and by exposing different portions of it to the surface in cultivation, we increase its fertility by hastening the formation of plant food.

The practice of "summer fallowing," which is sometimes followed, consists in preparing ground for a future crop ly plowing and harrowing repeatclly, so as to expose it as much as possible to the beneficial influences of the atmosphere.

4. To mix fertilizers with the so\%.

Plants thrire best, not where their roots find pure fertilizer in some spots, and poor soil in others, hut where the two are so completely mixed as to render the whe? a uniform medium of rich soil. 
'The benefit to be derived from both fertilizer and soil depends partly upon their combination with each other.

5. To kill weeds.

Weeds are injurions to growing erops in rarions ways:

(1.) By oceupying the soil to the exclusion of cultivated crops, and forming a shade, depriving them of the beneficial influences of smulight.

(2.) By withdrawing moisture from the soil, which is taken np as sap and transferred to the atmosphere through the leares. The amount of water thus remored from the soil, where weeds are numerous, may eause a crop to suffer from want of moisture, while a crop upon a neighboring plot free from weeds will be amply supplied.

(3.) By withdrawing food from the soil upon which crops would otherwise feed.

The quantity of arailable plant food in the soil at any time is limited. The strougest, most vigorous, and quickest growing plants are sure to olitain the greatest share. Most agricultural plants are not so rigorous when yommor as the ordinary weeds. Weeds grow much faster at first, and so tend to starve out other crops.

Weeds should always be destroyed when young and small. If allowed to grow until they attain considerable size, they damage the erop, and are more difficult to exterminate. They are plants, some varictics of which mirrt be of service in their proprer plares, but they cannot be made useful when growing in the midst of other crops.

Although returned to the soil, they reduce the arailahle fertility of the farm hy taking 11 the elements of plant food and converting them into resetable tissise, some of which may repuire years to be again transformed into soluble matter. 
6. To regulate the supply of moisture.

$A$ proper degree of moisture is an essential condition for the growth of crops. Either too much or too little is injurious.

During the hot summer months, howerer, when crops are growing fastest, they generally suffer more from a lack of moisture than from an oversmpply. In the case of "hoed" erops, the amount of moisture in the soil may be increased by proper cultivation.

In dry weather moisture fimls its way to the surface by capillary attraction, and evaporates rapidly. A "mulch," or light corering of straw, or leares, or any other substance, keeps the ground moist by retarding this evaporation. By stirring the surface soil and keepring it light and porous, a similar effect is produced, the loose soil serving as a muleh.

Since the pores in this soil are too large for eapillary action, the moisture fails to reach the surface.

7. To afford particular treatment to special crops.

There are some crops that require special treatment, or handling of the soil about them, to insure the most successful growtli.

Some plants, for instance, are supposed to thrive better when the soil is built up into "hills" abont them. The root crops require a soil made mellow to a great depth.

Plowing. - The plow has been regarded, throngh all ages of the world, as the characteristic implement of the farmer. The first plow erer used was nothing more than a stick of wood, with which the gromel was stirred or seratched. The history of the plow and its improvements eorresponds closely to the history of eivilization and improvenents in the art of agrieulture. It is still an indispensable implement of tillage. Thoronghness of 
cultivation and suecess in farming depend langely upon the plow and the use made of it.

Deep Plowing. - Is a general rule, ground is not plowed to a sufficient depth. The suil below that part which is stired in cultivation is generally of little direct service to erops.

The sulysoil is often too hard to allow roots to penetrate it freely. As it is buricel away from the atmosphere, the chemical changes which would convert its materials into plant food are very slow.

By bringing it to the surface, and mixing it with the fertilizers and fertile soil, these materials are marle more rapiclly arailable.

Eoonomy in farming requires that large crops shall be produced upon small areas. By decpening the eultivated soil, and thus enlarging the extent of space and increasing the supplies of food arailable to the roots of plants, we attain this end.

Deep tillage, also, has much to do with recrulating the supply of moisture. In wet seasons it affords drainage by providing more space for the surface water to pass into the porous soil beneatl.

In a time of drought, as the roots of elops have been able to extend themselves more deeply into the soil, they are able to obtain a supply of moisture, and are not so much injured by the drying of the surface.

While deep plowing has these adrantages, there are some cantions to be observed. To plow land at first much deeper than ever before, would hring to the surface a larege quantity of erurle soil. Unless a great amount of fertilizer is applied, this poor soil is liable to injure and rertarl the growth of youme plants hefore their roots can penctrate to the better soil below. This diffeulty 
may he avoided by making the deepening of the soil a grarlual process, plowing eateh time a little deeper than before.

Some sandy or allurial soils ale naturally so loose as to achnit ail and roots freely. Such soil, on the one hand, is not so much in need of deep plowing; and, on the other hand, if the lower portions are brought to the surface, they can do no harm, since they have become adapted for plants by the presence of air and the fertilizers which have been washed downward.

It may not aleays be wise to plow deeply. In the varied processes of eultiration, there may be occasions when shallow plowing will, for the time being, better accomplish the particular end desired; as, for example, when the lower soil is already sufficiently loose, and we simply wish to destroy weeds or mix fertilizers with the surface soil.

Subsoil Plowing. - The subsoil plow follows in the bottom of the furrow made by the ordinary plow, stirring the lower soil and allowing it to remain in the same position. By its use some of the adrantages of deep tillage are gained withont the necessity of bringing the poor sulisoil to the surface.

The Time to Plow. - It is an important question at what time plowing should be done; whether as long as possible before the seed is planted or just before, - in the fall or in the spring.

There are two sides to the question. After land is plowed, and exposed loosely to the atmosphere, ehemical changes go on more rapidly, eonverting the elements of fertility into a soluble form. On the other hand, the soil is more exposed to the washing of rain.

As all regetation has been destroyed by plowing, de- 
priving the soil of the presence of living roots, which would absorb and hold these clements, they are liable to be lost as fast as formed, moless the soil from its nature is able to retain then.

In general, the answer to the question will depend nyon the nature of the soil, the climate, and the particular erop to be raised.

A elayey or mucky soil would be free from the objection mentioned, while in the ease of a sandy or gravelly soil the loss by washing might be greater than the gain by exposme to the atmosphere.

In colel climates, where the gmomel remains frozen through the winter, there can be no loss during this season, and plowing in the fall gives land the henefit of the ermmbling and disintegrating effect of frost.

In climates where the glomel does not freeze, and where ram is abmolant during winter, there is a liahility of large loss loth by washing out the soluble clements, and by washing away the finest and richest parts of the soil.

For mising particular crops there may he special reasons for plowing in the fall or in the spring, aceording to the spereial wants of the erops. While geromed plowed in the fall has receired eertain changes from "xposme to the ald and the artion of frost, that plowed in the spring will naturally be more loose and porons.

Harrowing. - Next to the phow, the harrow is the most impurtant implement of agrienlture. The purpose of harrowing is chiefly to pulverize and level the soil, and a thorough performance of this work affords all the gencral advantages of tillace. It prepares the soil for roots, admits air, farors the formation of plant food, and thorombly mixes fertilizers with the soil. Experiments 
have shown that land well harrowed will yield better crops than land poorly harrowed, but supplied with a greater quantity of fertilizers.

Rolling. - Rolling is a useful process in tillage under certain circumstances. It crushes and pulverizes lumps of soil which have escaped the work of the harrow. When the soil is very dry and loose, rolling presses it more compactly about seeds, bringing them moisture by eapillary action, and hastening their germination and growth. It serves a good purpose in the spring, by pressing into the soil the roots of grass which have been thrown out by the action of frost. Clayey land, when wet, is injured by rolling, as the particles of soil are pressed too elosely together to admit air, and in drying form a hard erust upon the surface.

Cultivating. - The frequent cultivating or stirring of the surface soil between the rows of hoed erops, during the period of their active growth, is beneficial, both by killing weeds as soon as they appear, and preventing the loss of moisture. In every shower and rain-storm the particles of soil are washed and beaten together so eompactly as to eause moisture to rise to the surface by capillary action and eraporate. By loosening the surface soil repeatedly, this is prevented.

As the rootlets of plants ompletely fill the soil, approaching very near to the surface, this cultivation should generally be shallow. While the surface soil which is stirred in cultiration retains the moisture beneath, it becomes drier itself because of its loose condition.

By cultivating deeply among crops, we may prevent roots from occupying the upper portions of the soil, not only by repeatedly breaking them, but by rendering this part of the soil too dry. 
Draining. - The draining of hand, for the purpose of removing surplus water in wet scasons or in wet places, is accomplished either loy surface drains or by underdrains.

Surface drains, or ditches, are of some adrantage in removing the surplus accumulation of water from the surface of the ground. Besides being unsightly and inconvenient, they have the disadrantage of causing some of the richer portions of the surface soil to be washed away.

Underdrains are buried ont of sight, involve no waste, and accomplish the purpose more effectually. 'The general advantages to be gained by underdraining wet land are as follows : -

1. It renders the lower soil available to roots.

As the roots of most agricultural plants camnot live without the presence of oxygen, they camnot ocenpy soil which is completely saturated with water. Where the lower portions of soil are filled with water, roots are necessarily confined to the surface soil. By draining, we afford them an opportmity to make their way downward.

2. It atmits air to the lower soil.

From soil whose pores are filled with water, air is, of course, cxcluded. In such soil the formation of plant food mostly ceases. In a muck bog the humms retains its elements in an insoluble condition for centuries.

By draining the water ont of soil, we admit air, and provide for the formation of plant food.

3. It secures the benefits of rain.

Rain water, containing nitric acid, ammonia, ete., is a sonrce of fertility. In falling upon soil that is already filled with water, it camnot penctrate into the soil, but rums away upon the surface. Thus, the bencfits of the rain are lost. Where water is withdrawn from the soil 
ly drains underneath, falling rain, instead of flowing away, filters through the soil, and, exeept in case of loose sand or gravel, leaves its fertilizing elements behind.

4. It prevents the injurious effects of a dronglet.

In a time of drought, while the surface soil becomes very dry, there is gencrally sufficient moisture helow. If the lower portions have been previously saturated so as to prevent roots from ocenpring them, the plant is now mable to obtain a supfly of moisture, as its roots are surrounded with the dry surface soil ; but if the surplus water has been drained away, so that the roots have been able to make their way downward, when a dronght oecurs the plant may olstain its moisture through
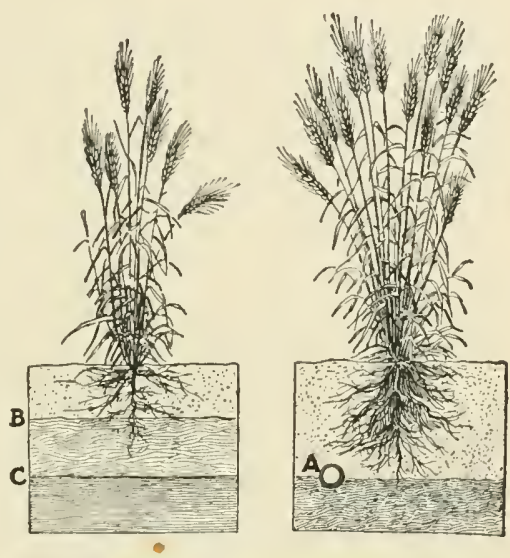

Effect of Underdrainage.

A, Drain-pipe. B, Point below which the soil is usuatly snturated. C', Point to which the water settles in a dry time. these lower roots.

\section{It renders wet land available for tillage.}

It is often the case that the wet lands upon the farm are the richest in plant food. Many low, wet places contain an aceumulation of regetable mold, and other fertile matter washed in from the land around them. By draining the water ont of these places, we render them permanent sourees of wealth.

Some farms are split up into small, irregular plots, ly narrow tracts of land, too wet for tillage. By draining 
these tracts, one contimuous field may be formed out of a number of plots, which is of great adrantage in the husiness of farming.

6. It increases the warmth of the soil.

The eraporation of water is a cooling process. It absorls heat from the substance from which the moisture escapes. An ohject may be cooled in hot weather by covering it with a damp cloth. I)amp clothing gives the hody a chill, not so much on aecont of the presenese of the moistnre in the clothing, as from its evaporation in drying. So wet land is always cool, because, on aceount of the presence of water, evaporation is always going on.

The warmenth of soil is promoted by drainage, not only by drawing the water away from leneath, and preventing evaporation, but also by admitting warm air.

Rotation of Crops. - A knowlerge of the fertility and cultivation of the soil is not complete withont an molerstanding of the principles involved in the rotation of crops, or an arrangement of different erops to oceupy the same land suecessively.

It is a familiar fact, that, when the same kind of erop is raised upon land year after year, the yield becomes less and less; and that, where one crop fails to yichl good returns, another may flourish. This fact leads to the practice of changing frequently from one crop to another.

The adrantages of this practice are as follows :-

1. It makes use of all the elements of plant food.

Different crops require the elements in different proportions. It is not often that these elements are supplied by the soil in the exact proportion required by any particular crop.

Potatoes, for example, require more potash than wheat, and wheat reguires more plosplowic acid than potaters. 
If potatoes should be raised upon the same land eontinuously, the supply of available potash would soon be exhansted, while there might still remain in the soil an excess of phosphoric acid.

In order to continue to raise potatoes upon this land, it would be necessing to underon the expense of adding a supply of potash. At the same time, the surplus of phosphoric acid, for which the potatocs have no use, might be washed out of the soil and wasted. If some crop, like wheat, reyniring more phosphoric aleir should be substituted for potatoes, a good crop' might be olstained, and in the mean time the decomposition going on in the soil would render a new supply of potash a railable.

2. It ke'ps the land oceupied.

Many of the enltivated crops have a slort season of growth. After they are harrested, the land remains moecupied until the following season.

During this time the formation of plant food in the soil is continued, and is liable to be lost, as there are no growing erops present to make nse of it.

By following the erop immorliately with some other, as winter grain, or grass, such loss may be avoided.

3. It prevents the loss of substances which have been washer dou'n into the sulssoil.

The roots of some plants naturally grow near the surface of the soil. In such cases, some of the elements of food may be washed down below the reach of these roots. By following with a erop whose roots tend to penetrate farther downward, these may be gathered up and saved.

Clover, which has a deep tap-root, will gonerally grow well after erops having hrauching roots, like wheat ol' barley; and, on the other hand, these will thrive well after rover. 
4. It secures the varied advantages of cultivating the soil.

When land is contimally oecupied with one erop, like grass, it ma heeome too harel and compact, and the formation of plant food may le ehecked. By stirring such soil, and exposing it to the atmosphere in enltivation, we hasten the chemical changes, and mulock the supjly of food which nature has in store.

There are many old meadows and pastures. regarded as worn ont and worthless, which, if subjected to thoromeh cultivation, might yield profitable returus.

5. It prevents the increase of ueeds rent injurious insirets.

In cultivating certain crops, we may supply conditions favorable to the growth of certain varieties of weods. If the elop' is continued in the same soil, these weeds will naturally increase. Propel management requires a change to some ofler erop with which such weeds will not thrive.

It is well known that injurious insects, like the potato beetle, will tend to inclease on land which is repeatedly ocempied by the jarticular crop upon which they are aceustomed to prey.

'The following are examples of rotations which are sometimes adopted :-

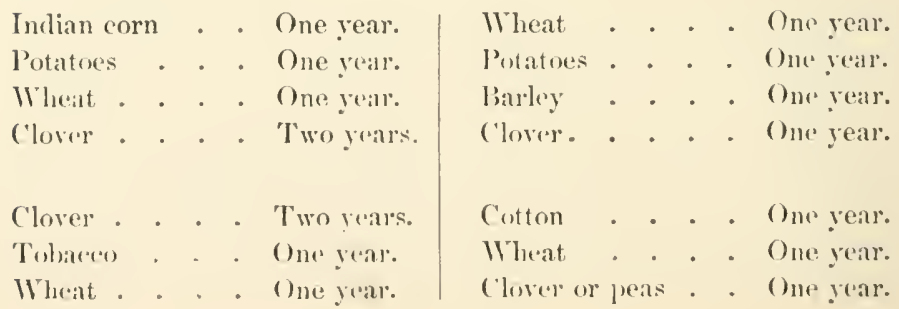




\section{QUESTIONS.}

What are the different purposes of cultivating the soil? What is the effect of leaving land in a lumpy condition? Name all the reasons you can think of why plants will not thrive in hard soil. Why do pliuts obtain more food in a loose soil? What reasons ean you give for mixing fertilizers thoronghly with the soil?

In what three ways do weerls injure crops? How do they dry the ground? Why should they be destroyed when small? Since they are not removed from the soil, how do they reduce its fertility?

In what way does enltivation increase the supply of moisture? Give several arguments in favor of deep plowing. Give several reasons why roots do not generally occups, to any great extent, the soil below that which is stirred in plowing.

What influenee has deep tillage upon the supply of moisture? What has it to do with economy in farming? Why is it unwise to plow very deeply at first? What kinds of soil may not need deep plowing? What are the advantages of subsoil plowing?

Name the arguments in favor of plowing in the fall. Give those in favor of plowing in the spring. What are the general conelusions in the matter? What are the advantages of thorough harrowing?

Name all the reasons you can think of why erops grow better in soil thoroughly pulverized. What are the advantages of rolling ground? Under what cireumstances is it injurious? What are the different benefits of cultivating hoed erops? Why should the ground be stirred after every rain-storm? Why shoukl this enltivation generally be shallow?

How may surplus watı: be carried away from a field? What are the disadvantages of surface drains? Nime the different alvantages of underdrains? Why do roots grow deeper where drains are provided? In what two ways do they renter land more fertile? How do they prevent land from suffering from a drought? Ilow do they render soil warmer?

What is neant by a rotation of crops? What are the advantages of a rotation? Give examples of rotations sometimes adopted.

Wiss. Agr. -8 


\title{
CIIAP'TER TII.
}

\author{
ANIMLALS.
}

THE two forms of life upon the earth are plants and supply the wants of animal life. The prineipal object in raising plants, or erops, in agriculture, is to obtain a supply of food for animals.

A knowledge of these erops is not eompleted until we have considered them as fed to animals to produce meat, milk, wool, work, cte.

It is very important to understand the nature, the peculiarities, the best methods of feeding, and the proper care and management of our domestic animals.

The Composition of the Bodies of Animals. - The bodies of animals are composed of rery nearly the same elements as plints.

Some animals, like the cow or horse, live mostly upon regetation, and are called herbierores, or plant-cating animals. Others, like the eat and dog, live largely upon the flesh of other animals, and are called carnirorous, or flesh-eating animals. Some live partly upon plants and partly upon animals and animal products.

But animal products, as meat, milk, egres, ete, are produecrl from regetalle matter, so that plants are the original source of all animal food.

The only sulbstanees that enter into the bodies of animals, aprart from plants, and animal products produced (114) 
from plants, are water, oxygen from the air, and small quantities of mineral matter, such as salt, lime, potash, etc., with which animals must be supplied when these are not furnished in sufficient quantity in the regular food.

The process of animal life consists in conrerting the sulstances of plants into the substances of the animal body, or in making them serve the different wants of the animal.

The substances forming the animal body may be divided into four classes : -

1. Water. - Water is generally the largest ingredient, comprising from one third to two thirds of the entire weight. It is essential to plants, furnishing a medium through which the elements of food may be distributed. In animals, it fills a similar office. It forms four fifths of the blood, and exists in the juices throughout all parts of the body.

2. Nitrogenous Sulistances. - Nitrogenous substances, or substanees containing nitrogen, are of first importanee in the animal body. They make up the musenlar tissue, or lean meat, the nerves, the skin, hair, wool, feathers, horns, ete. They also form a large part of the solid matter in the blood.

3. Fat.-Fat does not fill so important an office as the nitrogenous sulustanees. It does not make up the tissues and other essential parts of the body. It is always present, howerer, in greater or less quantity. Particles of fat are to be found seattered between the fibers of the museles. In well-fed animals fat is also stored up in large quantities beneath the skin, and about the bones and internal organs.

There are several varieties of animal fats, as stearin, 
palmitin, and olein. Some of them, like strarin, are hard, and some, like olvin, are either fluids or are easily milterl.

4. Ash. - The mineral parts of the animal are generally called the ash, because they are incombustible, or l'emain as ashes after burning. They are ehiefly found in the hones, where they are needed to give firmmess and hardness. They are eomposed ehiefly of phosphate of lime, carbonate of line, phosphate of magnesimm, and phosphate of potassimm.

The following table will give an idea of the average perentage composition of the bodies of domestic animals, after deducting the contents of the stomach and intestines : -

\section{Composition of Bodies of Animals.}

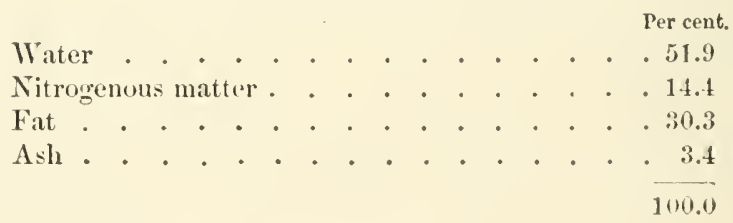

The Purposes of Food. - The different pmposes which food must serve in the animal system are:-

1. To increase the size of the Body. - Mature animals, whose size and weight remain emstant, require no food for this purpose; but in young, growing animals, and those passing from a lean to a fat conclition, the gradual increase in weight must come from the food consumed.

'The formation of animal products, like milk, must be elassed under this head, since the substances of which milk is eomposed first become a part of the amimal, and are then converted into milk. 
2. To repair Waste or supply Mechanical Force.'The particles of matter of which the hodies of animals are composed do not remain fixed and permanent. They are constantly being removed and replaced by new particles. After a time the particles become old, and no longer useful, and new particles are formed from the food to take their place.

$\Lambda$ constant exchange is thus going on in all parts of the body, so that after a number of years a new body is formed, no part of the old remaining. The only exception to this is the enamel upon the teeth, which is believed to remain without change.

'This wasting, or wearing away, of the substances of the body is increased by work or muscular exertion. The body is nerer at rest. When asleep, or when perfeetly quiet, the lieart still beats to force the blood through the body, and the lungs are regularly expanded to draw the breath. Every morement requires force, and this foree is supplied eitler by food, or by particles of the body which nust be replaced by the food.

The foree that drives a train of cars comes from the consumption, or burning, of fuel under the boiler; so the force to produce motions of the body is obtained by chemical processes, which either consume the elements of food or particles of the body which, have been formed from food.

3. To supply Heat. - The temperature of the bodies of animals, when in a healthy condition, is from $98^{\circ}$ to $100^{\circ}$. It cannot be allowed to vary many degrees from this point, for any considerable time, without causing death. In cold and hot climates, in winter and in summer, it must be kept constantly the same. When the 
body beeomes too walm, it is cooled by the evaporation of perspination from the skin.

As the air is generally cooler than the bodies of animals, it is constantly cooling them. To take the place of the heat thus withdrawn, it is necessary that a new supjuly be constantly fumished in the system. This is produced by burning, or oxidizing, a portion of the food, or particles of the body. The oxygen for this process is obtainel from the air through the lungs.

The Composition of Foods. - The food of animals contains six different classes of substances, as follows :-

1. Water. - All articles of food contain more or less moisture. Hay and meal, which aplear to be perfectly dry, contain from ten to twenty per cent. water. Suceulent food, like green fodder and roots, may contain from siventy to ninety-five perecent. water. In addition to that contained in the food, the animal must drink enough to supply the wants of the system.

2. Albuminoids. - The albuminoids of food, sometimes called protein, are the parts containing nitrogen. They are often called "flesh formers." They serve to form the flesh, ol muscle, and the other nitrogenous parts of the borly.

The alluminoids contain not only nitrogen, which is used in forming the museles, but also other elements of an entirely different nature, which serve to supply heat or force. The alluminoids may thus be made to supply all the wants of the body; but to confine animals to a diet composed entirely of nitrogenous foort would be a wasteful practice. The albmminoids contain a larger proportion of nitrogen than animals require. After a sufficient quantity of such food has been consumed to supply enomgh nitrogen, it is necessary to consume an 
additional quantity in order to obtain enongh of those elements which supply heat and foree. 'The nitrogen of this second quantity is wated, since the animal has no further use for it. Heat and foree may be more ceonomically supplied with foods containing less nitrogen.

Amilles are another class of substances containing nitrogen. They exist to some extent in rarious kinds of food, particularly in green or immature folder plants, and in regetables. They are less valuable than alluminoids, since their nitrogen cannot be used to form the tissues of the body. They can only serve, like fats and carbo-hydrates, to produce heat and force. As they are found only in small quantities, and are comparatively of little importance, they have not generally been distinguished from other elements in making an analysis of foods.

Protein is a term used to include both the albuminoids and the amides, or all parts of food which contain nitrogen.

3. Fat. - The fatty parts of food correspond to the fats of animals. 'They are either oxidized to produce heat and mechanical energy, or are stored up in the system for future use. 'They are the most valualle class of sulustances for producing heat and energy. For these purposes they are worth about twice as much as the same amomt of albuminoids. As they do not contain nitrogen, they cannot be used in forming the tissues of the body.

4. Carbo-hydrates. - The carbo-hydrates of foor comprise such substances as starch, sugar, cellulose, etc. They are composed of carbon, hydrogen, and oxygen. The term hydrates is applied to them from the Greek word hudor, meaning water, because their hydrogen and 
oxygen when separated from the carbon would form water.

'They are cither oxidized in the body to produce heat and energy, or are converted into fat. 'They are the least valuable of the digestible parts of food. Stareh is an important part of these substances, and about two and one half parts of stareh are repuired to produce the same effect as one part of fat.

5. Filier. - Most kinds of food contain more or less cmole woody fiber, which is mostly indigestible and hence has little ralue as food.

6. Ash. - The mincral substances in fool, or those which would remain as ashes after hurning, are also needed by the animal in about the same propostion as they exist in the arerage of the different varieties of food. When animals are confined to one particular kind of food, some of these substances may be deficient. Althowgh the amomnt required is small, they eamot be dispensed with. Animals fed exclusirely upon corn moal sometimes lose the use of their legs from the want of suffieient mineral matter to form bones.

On the page opposite is a talile of some of the more common foods, with their arerage perentage composition, as determined hy chemical analysis.

While the list gives the arepage results from a large mumber of separate tests, and must be approximately eorrect, it should be remembered that different samples differ widely in their nature.

There would be a wide difference, for instanee, between the eomposition of early and late cut hay, or hetween mripe and nuture com forlder.

While these figmes may not acemately represent the composition of any particular sample of food, they 
will serve well enough as a general guide for praetical purposes.

Average Percentage Comprosition of Articles of Fond.

\begin{tabular}{|c|c|c|c|c|c|c|c|c|c|}
\hline \multicolumn{4}{|c|}{ Kinds of Food. } & \multirow{2}{*}{$\begin{array}{l}\text { Water. } \\
11.32\end{array}$} & \multirow{2}{*}{$\begin{array}{l}\text { Ash. } \\
5.76\end{array}$} & \multirow{2}{*}{$\begin{array}{c}\begin{array}{c}\text { Albuusi- } \\
\text { noids or } \\
\text { Protein. }\end{array} \\
8.51\end{array}$} & \multirow{2}{*}{$\begin{array}{l}\text { Fat. } \\
2.21\end{array}$} & \multirow{2}{*}{$\begin{array}{c}\text { Carbo- } \\
\text { hydrates. } \\
41.38\end{array}$} & \multirow{2}{*}{$\begin{array}{l}\text { Fiber. } \\
30.82\end{array}$} \\
\hline Average laay & . & & . & & & & & & \\
\hline Clover hay & & & & 12.56 & 6.10 & 12.61 & 2.48 & 39.62 & 26.63 \\
\hline 'T'imotlyy hay & • & & & 11.07 & 4.06 & 6.02 & 2.16 & 45.80 & 30.89 \\
\hline Oat straw & . & . & . & 9.62 & 5.20 & 3.51 & 2.21 & 30.09 & 43.37 \\
\hline Wheat straw & - & 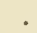 & . & 6.50 & 6.90 & 4.98 & 1.49 & 41.99 & 38.08 \\
\hline Rice straw . & . & & . & 3.66 & 10.71 & 4.68 & 1.74 & 50.90 & 28.31 \\
\hline Corn fodder & & & . & 3205 & 4.32 & 4.29 & 1.21 & $35 . ! 6$ & 22.14 \\
\hline Fodder corn (g & gree & & & 80.98 & 1.13 & 1.62 & 0.41 & 10.62 & 5.23 \\
\hline Ensilage (Nort) & hier & $1(0)$ & ru) & 70.55 & 1.05 & 2.65 & 0.90 & 18.84 & 6.00 \\
\hline Eusilage (IV est & tern & $\mathrm{cor}$ & n) & 80.47 & 1.35 & 1.51 & 0.70 & 10.21 & 5.77 \\
\hline Cow-pea vines & (dri & ed) & & 11.05 & 8.41 & 15.68 & 2.87 & 42.17 & 19.82 \\
\hline Indian corn. & . & & . & 10.10 & 1.55 & 10.34 & 5.13 & 70.59 & 2.29 \\
\hline Oats... & . & & & 10.94 & 2.97 & 11.38 & 4.81 & 60. & 9.85 \\
\hline Barley . . & 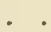 & & & 10.92 & 2.88 & 1239 & 1.86 & 69.88 & 2.57 \\
\hline Wheat . & 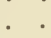 & & & 10.54 & 0.86 & 11.80 & 2.11 & 72.8 & 1.80 \\
\hline Rice . . & & & & 14.80 & 0.80 & 7.50 & 0.50 & 76.00 & 0.90 \\
\hline Buckwheat. & & & & 12.60 & 2.00 & 10.00 & 2.20 & 64.50 & 8.70 \\
\hline Peas . . & & & . & 14.30 & 2.40 & 2240 & 2.00 & 52.50 & 6.40 \\
\hline Sorghum (grai & in) & & & 12.52 & 1.80 & 8.88 & 3.65 & 71.27 & 1.88 \\
\hline Wheat bran & & & & 12.42 & 5.68 & $15.0: 3$ & 3.74 & 54.17 & 8.96 \\
\hline Wheat middlin & ags & & & 12.00 & 3.18 & 14.88 & 389 & 61.55 & 4.55 \\
\hline Cotton-seed me & eal. & & . & 8.39 & 7.25 & 42.06 & $1: 24$ & 29.49 & 5.69 \\
\hline Linseed meal (o & olı! & & 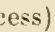 & 920 & 5.87 & $31.5: 3$ & 7.78 & 8684 & 9.28 \\
\hline Gluten meal & & & & 9.15 & 0.78 & 29.88 & 6.11 & $5: 192$ & 1.46 \\
\hline Brewers' grain & is (d) & rier & & 8.19 & 3.58 & 19.89 & 5.56 & 5175 & 11.03 \\
\hline Apples & & & & & 0.4 & & & 11 & 4.8 \\
\hline l'umpkins & 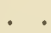 & & • & 89.1 & 1. & 0.6 & 0.1 & 6.5 & 2.7 \\
\hline Potatoes. & & & & 7 & 0 & 21 & 11.2 & 20.7 & 1.1 \\
\hline Turnips. . & & & • & 92 & 0. & 1.1 & 0.1 & 5.3 & 0.8 \\
\hline Beets (sugar) & . & • & . & 87.0 & 0.9 & 2.0 & 0.1 & 9.2 & 0.8 \\
\hline Milk . . . & & & . & & 0.7 & 3.2 & 3.6 & 5.0 & \\
\hline skimmed milk & & & . & 10 & 0.8 & 3.5 & 0.7 & 50 & \\
\hline Buttermilk. & . & • & . & 90.1 & 0.5 & 3.0 & 1.0 & 5.4 & \\
\hline Whey . & . & . & . & 92.6 & 0.7 & 1.0 & 0.6 & 5.1 & \\
\hline
\end{tabular}

The Value of Foods. - The value of any food is determined, not by the substances which it contains, but by 
the amount of these sulostances that ean be diyested and become useful to the animal.

There are but few articles of food of which all the albuminoirls, fats, and calbo-hydrates can be thus dierested. The indigestible part is of no value for ford.

The table on the oplosite jage gives the pereentage of digestible allouminoids, fats, and carho-hydrates contained in the different articles of food, and the value of one humdred pomds of each variety.

In reckoning these values, the digestible albuminoils and fats are, according to the usual custom, regarded as worth $t \frac{1}{3}$ eents per pound, and the digestible carioliydrates as worth $\frac{9}{10}$ of a eent per pound.

The results are, of eourse, only relative, and will rary aceording to the market ralue of the standard articles of food in any locality. If average hay is worth sixtyfour cents per humdred pounds, or \$12.80 per ton, then the other articles will be worth the sums given in the table as compared with hay.

If in any locality, or any year, the marliet value of hay, eorn, oats, or other articles commonly used, is greater or less, upon the average, than the table indicates, then the fignres for all the articles mentioned must be increased or diminished accorlingly.

'The table affords a general gruide for seleeting and jurchasing fools, but it must not be dejended npon for great exactness. No article of food can, in reality, have an absolute value of its own. The true value of any article as food depends mon its eombination with other foods, the nature of the animal to which it is ferl, and the mupose to he accomplished. In order to make an intelligent selection, it is necessary to understand what particular kinds of food are needed in the given case. 
Percentrige of l ligestible Substances and I tulue of 100 Pounds of the Food.

\begin{tabular}{|c|c|c|c|c|c|c|c|}
\hline \multicolumn{4}{|c|}{ Kinds of Food. } & \multirow{2}{*}{$\begin{array}{c}\begin{array}{c}\text { Abuminoids } \\
\text { or } \\
\text { Protein. }\end{array} \\
5.40\end{array}$} & \multirow{2}{*}{$\begin{array}{l}\text { Fat. } \\
1.00\end{array}$} & \multirow{2}{*}{$\begin{array}{l}\begin{array}{c}\text { Carbo- } \\
\text { hydrates, in- } \\
\text { cluding tiber }\end{array} \\
41.00\end{array}$} & \multirow{2}{*}{$\begin{array}{c}\begin{array}{c}\text { Value of } \\
100 \text { lounds. }\end{array} \\
\$ 0.64\end{array}$} \\
\hline Average laay & . & . & • . . & & & & \\
\hline Clover hay & . & . & . . & 7.82 & $1.4 !$ & 40.25 & 0.77 \\
\hline 'Timotlyy liay & - & - & . & 4.67 & 1.03 & 41.25 & 0.62 \\
\hline ()at straw & . & . & . & 1.14 & 0.66 & $42.6 i 2$ & 0.47 \\
\hline Wlieat straw & - & - & . & 0.85 & 0.54 & 37.70 & 0.39 \\
\hline Rice straw . & - & . & . & 1.92 & 0.52 & 40.40 & 0.46 \\
\hline Corm forlier & . & . & . & 3.00 & 0.03 & 40.00 & 0.53 \\
\hline Fodder corn (g & reel & 11). & - . & 1.19 & 0.31 & 10.87 & 0.16 \\
\hline Ensilage (IVest & tern & $1 \mathrm{col}$ & ril) & 1.10 & 0.53 & 10.99 & 0.17 \\
\hline Cow-pea vines & (dri & ied) & & 9.56 & 1.31 & 37.02 & 0.80 \\
\hline Indian corı. & . & - & . & 8. 16 & 4.36 & 6.564 & 1.13 \\
\hline Oats . . . & . & & . & 8.46 & 394 & 4611 & 0.95 \\
\hline Barley · . & - & - & . & 9.64 & 1.86 & 60.77 & 1.04 \\
\hline Wheat. . & . & . & . & 9.32 & 1.79 & 66.52 & 1.05 \\
\hline Rice : . . & . & . & . & 5.92 & 0.42 & 70.71 & 0.91 \\
\hline Buckwlieat . & . & - & . & 7.70 & 1.84 & 49.21 & 0.86 \\
\hline Peas . . & . & . & . & 20.20 & 1.70 & 54.40 & 1.44 \\
\hline Sorglıum (graiı & & . & . & 6.81 & 2.99 & 5.3 .06 & 0.90 \\
\hline Wheat bran. & . & - & . & 11.72 & 2.58 & $44.66^{\circ}$ & 1.02 \\
\hline Wheat middlin & gs & - & . & 11.60 & 2.68 & 48.87 & 1.06 \\
\hline Cotton-seed me & al & . . & $\cdot$ & 3575 & 11.65 & 22.25 & 2.25 \\
\hline Linseed meal (o) & $\mathrm{l}_{1}$ & roc & cess) & 25.85 & 7.08 & 26.52 & 160 \\
\hline Gluten meal : & . & & . & 23.80 & 3.85 & 50.92 & 1.63 \\
\hline Brewers'grains & (dr & ie(l) & ) . & 11.52 & 4.77 & 37.41 & 1.20 \\
\hline Apples : · & - & & & 0.3 & & 12.9 & 0.13 \\
\hline Pumpkins . & . & - & - & 0.1 & 0.1 & 7.1 & 0.08 \\
\hline Potatoes. & . & . & . & 2.1 & 0.2 & 21.8 & 0.30 \\
\hline 'Turuips . . & . & . & . & 1.1 & 0.1 & 6.1 & 0.11 \\
\hline Milk . . . & . & . & . & 3.2 & 8.6 & 5.0 & 0.34 \\
\hline Skimned milk & . & - & - & 3.5 & 0.7 & 5.0 & 0.23 \\
\hline Buttermilk . & • & - & - & 3.0 & 1.0 & 5.4 & 0.22 \\
\hline Wliey . • · & - & . & - & 1.0 & 0.6 & 5.1 & 0.11 \\
\hline
\end{tabular}

Esonomy in Feeding. - There are two general precepts to be observed in connection with the economical feeding of stock : -

1. Feed animals as much as they can digest without injuring their health.

The profits of feeding stock come either from the 
work which they are enabled to perform, or fromk growth and animal products.

It reguires a certain amomnt of food to maintain life. If just enough is ferl to keep up the vital processes of the animal and prevent shrinkige of weight, it is evident that the cost of keeping is alsolutely lost to the owner, mless, on aceoment of the variation of malket prices, the animal is to le worth nore at some future time.

Whatever the animal consumes, digests, and assimilates, in excess of what is required to maintain life, will le a somree of profit, as it will yicld either foree for work or animal products.

Generally speaking, the more food the animal eats and digests, the greater is the profit, as the ratio of gain to the foorl cousumed is greater. If it slould require ten pomrls of food per day to maintain the life of a eertain animal, and three pounds of food in addition to produce a gain of one pound of flesh, then a ration of thirtecen pomds of food would produce a daily gain of one pomm of flesh. A ration of sixtecn pounds would produce a gain of two pounds of flesh. In the former case the ratio of gain to foor is one to thirtecn, and in the latter case one to eight.

'This principle is limiter, howerer, by the digestive power of the aninal. Any exeess of food alowe the (puantity that ean be properly digested may lead to disease and loss.

2. Feed a balaned ration.

Animals shomld be supplied with food, the composition of which is in proportion to their nects.

As the fats and rarlo-hydrates of food are of a similar mature, and serve a similar purpose, it is enstomary, for 
the sake of convenience, to class them together. The fats are reckoned as worth 2.44 times as much as carbohydrates; henee, in eombining the two, we multiply the number of pomds of fat by 2.t4, and add the number of pounds of earbo-hydrates, giving what may be called the equiralent of carbo-hydrates contained in the food.

The ruestion of food for any animal, and for any purpose, becomes a question of the proper proportion of albuminoids and carbo-hydrates. 'The animal needs, for' its special requirements, a certain definite proportion of each.

If we furnish a food eontaining too large a proportion of either albuminoids or earbo-hydrates, the excess of either above what is required to make up the proper proportion for the given purpose may be in part wasted, and may become an injury rather than a benefit to the animal. The animal must consume a larger quantity of the food than would otherwise be necessary, in order to obtain the required quantity of that substance in which the food is most defieient.

The Nutritive Ratio. - The nutritive ratio of a food is simply the ratio, or relation, between the quantity of digestible allmminoids, and of digestible carbo-hydrates or their equivalents, which it contains. Arerage hay, for instance, contains about eight times as much of digestible carbo-hydrates as of alluminoids, and hence the mutritive ratio of the food is as 1 to 8 .

'The following tables give the nutritive ratio of the different kinds of food, and the number of pounds of digestible albuminoids and earbo-hydrates which should properly be contained in the daily ration of animals under different eireumstances, for one thousand pounds of live weight. The quantity for animals weighing more or 
less than one thomsand pounds is found by increasing or diminishing the given amounts proportionately. 'Thus, a horse weighing twelve humbed pounds shonld receive one fifth mole than the amounts given for one thousand pounds.

Albuminoids, Equiralent of Carbo-hydrutes, and Nutritive Ratio.

\begin{tabular}{|c|c|c|c|c|c|c|}
\hline \multirow{2}{*}{\multicolumn{4}{|c|}{ linds of food. }} & \multicolumn{2}{|c|}{ Digestible } & \multirow{2}{*}{$\begin{array}{c}\text { Nutritive } \\
\text { Ratio. }\end{array}$} \\
\hline & & & & \multirow{2}{*}{$\frac{\text { Albuminoids. }}{5.40}$} & \multirow{2}{*}{$\frac{\begin{array}{c}\text { Carbo-hydrates } \\
\text { with Fat } \times 2.44 .\end{array}}{4344}$} & \\
\hline Average hay. & & & . & & & 1 to 8 \\
\hline Clover hay. . & . & - & . & 7.82 & 43.89 & 1 to 5.6 \\
\hline 'Timothy hay . & • & . & . & 4.67 & 43.76 & 1 to 9.4 \\
\hline Oat striw & . & - & . & 1.44 & 44.23 & 1 to 30.7 \\
\hline Wheat siraw & • & - & . & 0.85 & 39.02 & 1 to 45.9 \\
\hline Rice straw. & & . & . & 1.92 & 41.67 & 1 to 21.7 \\
\hline Corn fodder. & . . & . & . & 3.00 & 42.27 & 1 to 14 \\
\hline Fodder corn (g & ree & & . & 1.19 & 11.63 & 1 to 9.8 \\
\hline Insilage (IVes & terr & con & n) & 1.10 & 12.28 & 1 to 11.2 \\
\hline Cow-pea vines & (dri & e(I) & . & 9.56 & 40.29 & 1 to 4.2 \\
\hline Indian corn & & . & . & 8.16 & 76.28 & 1 to 9.3 \\
\hline Oats . . & & - & . & 8.46 & 55.72 & 1 to 6.6 \\
\hline liarley . . & & . & . & 9.134 & 65.31 & 1 io 6.8 \\
\hline Wheat. & & . & . & 9.82 & 70.89 & 1 to 7.7 \\
\hline lice . . & & . & . & 5.92 & 71.73 & 1 to 12.1 \\
\hline Buckwheat & & . & - & 7.70 & $5: 3.70$ & 1 to 7 \\
\hline l'eas . . : & & - & . & 20.20 & 58.55 & 1 to 2.9 \\
\hline Srorghum (grain & & . & - & 6.81 & 60.90 & 8.9 \\
\hline Wheat bran. & . & . & - & 11.72 & 501.90 & 1 to 4.3 \\
\hline Wheat middlin & $\operatorname{lgs}$ & . & . & 11.60 & 55.41 & 1 to 4.8 \\
\hline Cotton-seed me & al & . & . & 85.75 & 5068 & 1 to 1.4 \\
\hline Linseed meal (c & old & proc & ess & 25.8 .1 & $4: 3.80$ & 1 to 1.7 \\
\hline Gluten meal. & & & & $2: 3.30$ & 60.26 & 1 to 26 \\
\hline 13rewers' grain & s ( & ried & & 14.52 & 49.05 & 1 to 3.4 \\
\hline Apples . . & . & . & . & 0.30 & 12.90 & 1 to 4.3 \\
\hline Pumpkins. & . & . & - & 0.40 & 7.34 & 1 to 18.4 \\
\hline Potatoes. . & . & . & . & 210 & 22.29 & 1 to 10.6 \\
\hline 'Turnips . . & - & . & - & 1.10 & 6.34 & 1 to 5.8 \\
\hline Milk . . . & & & & 320 & 12.78 & 1 to 4.3 \\
\hline Skimmed milk & & . & . & 3.50 & 6.71 & 1 to 1.9 \\
\hline Buttermilk. & . & . & . & 8.00 & 7.84 & 1 to $21 ;$ \\
\hline Whey . . & . & . & - & 1.00 & 6.56 & 1 to 6.6 \\
\hline
\end{tabular}


Food required for different Animals, for 1,000 Pounds, live weight.

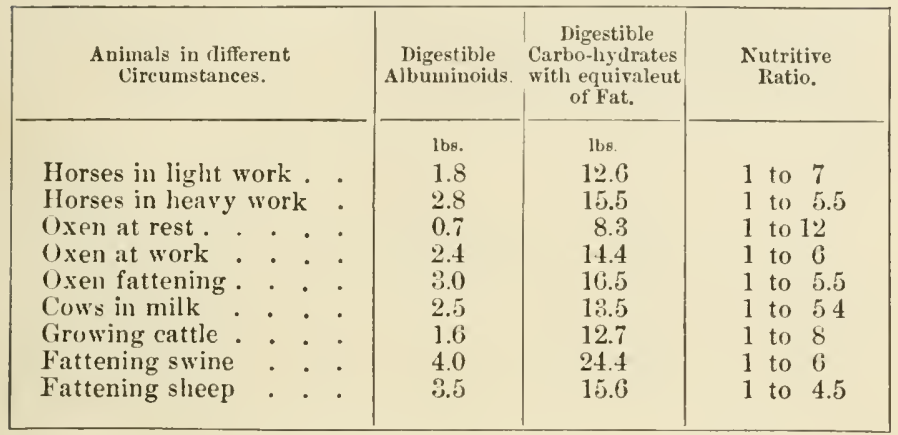

Rations. - To make up a balanced ration, we have simply to reckon the quantity of digestible albuminoids and carbo-hydrates contained in a certain amount of the different articles of food in question, varying the quantity of each article to meet the wants of the ease.

If, in making up a trial combination, we find we have too large a proportion of albuminoids, then we should increase the proportional part of those articles in the ration which are more largely composed of carbohydrates, and vice versa.

Strict aceuracy is not necessary. If the result is within a fraction of what is theoretically required, it is near enongh for practical purposes.

The question whether the ration is properly balanced should always be considered in making a combination of foods. It is not always necessary, however, to follow the theory strictly. Some allowance may be made for market prices.

If either the nitrogenons foods or the carbonaceous foods are relatively much cheaper in the markets, a larger proportion of the cheaper class may be admitted 
into the ration for the sake of economy. 'The difference in cost may be suffieient to orereome the loss caused by feeding an incorrect ration.

The following sample rations will illustrate the methorl :-

lation fur a Cou, weighing 1,0 O Pounds, giving . Vilk.

\begin{tabular}{|c|c|c|c|}
\hline \multirow{2}{*}{\multicolumn{2}{|c|}{ Duily Ration. }} & \multicolumn{2}{|c|}{ Digestible. } \\
\hline & & Albuminoids & Carbo-hydrates. \\
\hline $\begin{array}{l}\text { English hay, } 15 \text { lbs. furnishing : } \\
\text { Ensilage, } 15 \text { lbs. furnibhing } \\
\text { Cotton-seed meal, } 2 \text { lbs. furnisting } \\
\text { Wheat middiings, } 7 \text { lbs. furnishing }\end{array}$ & $\begin{array}{l}\cdot: \\
: \\
\dot{ }:\end{array}$ & $\begin{array}{l}16 s \\
081 \\
0.17 \\
0.72 \\
0.81\end{array}$ & $\begin{array}{l}1 \mathrm{bs} . \\
6.52 \\
1.84 \\
1.01 \\
3.88\end{array}$ \\
\hline 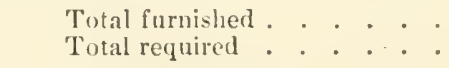 & : & $\begin{array}{l}2.51 \\
2.5\end{array}$ & $\begin{array}{l}13.25 \\
13.5\end{array}$ \\
\hline 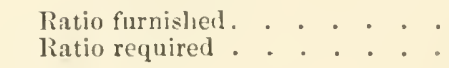 & $\therefore$ & \multicolumn{2}{|c|}{$\begin{array}{l}1 \text { to } 5.3 \\
1 \text { to } 5.4\end{array}$} \\
\hline
\end{tabular}

Iiution for a llorse, weighing 1,203 Pounds, at light II ork.

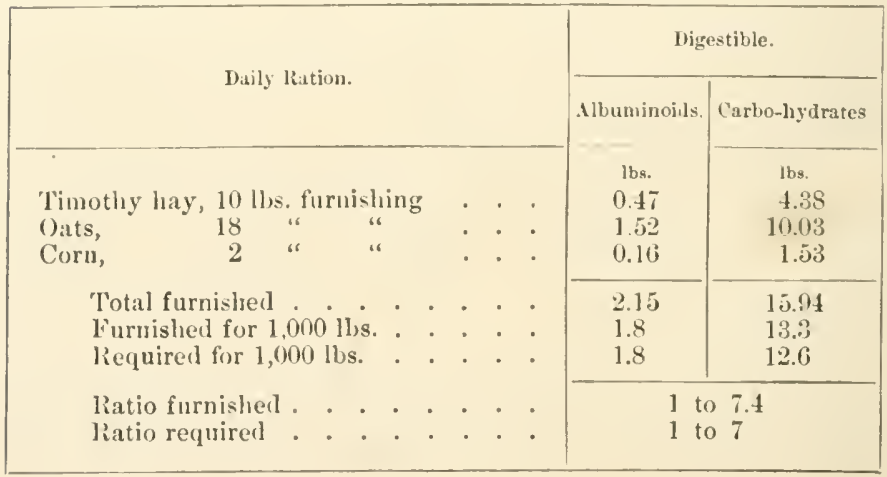


Ration for a Fattening Hog, veighing 200 Pounds.

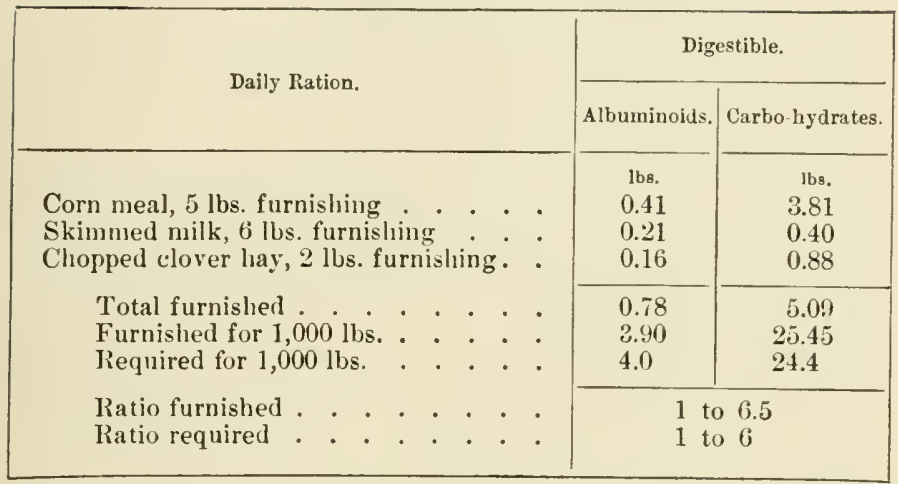

Variety of Food. - In order that animals may be always kept in a healthful and thriving condition, they should be supplied with a variety of food. Although a single kind of food, or some particular combination of two or more kinds, may contain the allonminoids and carbo-hyrlates in proper proportion, it is unwise to confine an animal to one special diet for a long time. The appetite and digestion are improved by furnishing a greater variety.

In computing a ration, we do not take into aceount the mineral sulstances contained in it. Although the quantities of these required are small, they are essential to perfect health. A particular ration may not contain sufficient quantities of all of these, and after a time the lack may cause injurious results. By furnishing a greater varicty, or changing the ration frequently, we may kecp) the rarious wants of the animal more prerfectly supplied.

The Manurial Value of Food. - In selecting foor for animals upon the farm, the cost of the food and its value for supporting animals are not the only points to be WINS. $A G_{1}-9$ 
(nusidered. We should also take into aceount its manurial value, or value as a fertilizer.

Iny kind of food has a certain value as a fertilizer, and may be used directly for that lurpose if it is not too expensive.

Cotton-seed is extensively used in this way in the Sonth.

The mammial value, as in ordinary fertilizers, is defermined by the anoment of nitrogen, phosploric acid, and potash contained.

The following table shows the number of poumts of the three substances contained in one tou of each varicty of fool, and the mammrial value of a tom. 'This ralue is, of course, variable, depending mpon the market ralue of the three substances for the locality and the season.

Manurial Substaners in a Ton of Food, and their T'ulue.

\begin{tabular}{|c|c|c|c|c|c|c|c|c|c|}
\hline \multicolumn{6}{|c|}{ Kinds of food. } & Nitrogen. & $\begin{array}{l}\text { Whosphoric } \\
\text { Aciul. }\end{array}$ & Potash. & $\begin{array}{l}\text { Value in } \\
\text { a Ton. }\end{array}$ \\
\hline Colmon-scet mo & eal & & . & & . & $\begin{array}{c}\text { lbs. } \\
\text { I. } 2.0 .0\end{array}$ & $\begin{array}{l}\text { lbs. } \\
56,0\end{array}$ & $\begin{array}{l}\text { los. } \\
4: 2.0\end{array}$ & s.966 66 \\
\hline Linscred meal & . & . & . & . & . & (1) 0 & 39.2 & 29.4 & 19.01 \\
\hline Wheat hran & . & & . & 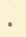 & . & 44.0 & 64.6 & 29,6 & 19.69 \\
\hline Beans. . & . & . & . & 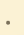 & - & $8: 0$ & 28.2 & 24.0 & 16.18 \\
\hline l'eas . . . & . & . & . & - & . & 72.0 & 17.6 & $1 ! 1.6$ & 13.91 \\
\hline ()ats. . . & - & - & . & . & - & 41.2 & 12.4 & $(1.0)$ & 8.013 \\
\hline Barley . & . & . & . & . & . & $: 34.0$ & 14.6 & 9.8 & 7.10 \\
\hline Wheat. & . & . & . & & . & $: 37.16$ & 16.0 & 10.8 & 7.84 \\
\hline Indian rorn & . & . & . & . & . & $2: 3.2$ & 12.2 & 7.2 & 6.05 \\
\hline Buckwherel. & . & . & . & - & . & 28.8 & 8.8 & 4.2 & 5.52 \\
\hline Average laay & . & . & - & - & . & 31.0 & 7.6 & 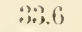 & 7.25 \\
\hline Timotlyy hay & . & . & . & • & . & 81.0 & $1: 3.6$ & 34.4 & 7.77 \\
\hline 1)eal ripe liay & & . & . & * & . & 240 & 5.8 & 10.0 & 4.80 \\
\hline Clover hay. & . & . & . & $\bullet$ & . & $: 91.4$ & 11.2 & 89.0 & 9.15 \\
\hline Beall straw. & . & . & . & $\cdot$ & . & 20.0 & 8.2 & 51.8 & 6.45 \\
\hline (1)al straw . & . & . & . & • & . & 30.0 & 5.0 & 20.8 & 3.11 .4 \\
\hline Wheat straw & . & . & . & . & . & 9.6 & 5.2 & 11.6 & 2.53 \\
\hline Corn fodler & - & - & . & . & . & 16.0 & 15.2 & Giti.4 & 7.10 \\
\hline Potalnes. & - & • & & - & • & 6.8 & 3.6 & 11.2 & 1.94 \\
\hline 'Turnips. & . & • & . & & - & 8.6 & 1.2 & 5.8 & 0.96 \\
\hline
\end{tabular}


Differences in the quality of the food will also cause rariation, as in reckoning the feeding value.

The figures giren are obtained by reckoning the nitrogen at sixteen cents per pound, the phosphoric acid at eight cents, and the potash at fire cents.

The values of these sulstances are reckoned the same, in whaterer food they are found. There is, however, some difference in point of fact, since in some articles of food they are in a more arailable condition than in others, and can be made more immediately serviceable as fertilizers.

The Value of Manure from Food. - To determine the real value of the manure from different kinds of food, a deduction must be marle from the total manurial value for certain losses that occur.

1. We must deduct the amount which the animal remores from the food in digestion. This may be reckoned upon the average at fifteen per ecent.

2. 'The three sulistances are not $\mathrm{g}$ nerally so valuable in stable mantre as in commercial fertilizers, becanse they are not so largely available at first, and are subject to greater losses before they can be used for plant ford. Probably twenty per cent. should be deducted on this aceount.

It must also be remembered that, in addition to these deductions, there is always more or less loss from fermentation and drainage; but this is so rariable that it cannot be definitely stated. It can only be estimated in individnal cases, after a knowledge of the facts involved.

All articles of foor feel to stock upon the farm have thus a double value: a feeding value, determined by the digestible albuminoids and carbo-hỵdrates; and a manurial value, determined by the amount of nitrogen, plos. phoric acid, and potash in the manure. 
The following table grives these two values separately and eombined:

Double Iulue of Founl, per Ton.

\begin{tabular}{|c|c|c|c|c|c|c|c|c|c|c|}
\hline \multicolumn{8}{|c|}{ linels of Food. } & Vitue for & Value of & Double \\
\hline Cotton-seed n & neal & 1 . & . & . & . & . & . & $\$ 4.000$ & 518.13 & s6:; 13 \\
\hline Linseed meal & . & . & . & . & . & . & . & $3: 3.20$ & 12.913 & 4ti. 13 \\
\hline Wheat bran. & . & . & . & . & . & . & . & $20.41)$ & $9 . .31$ & 29.11 \\
\hline Peas... & . & - & . & . & . & . & . & 28.811 & 9.40 & 38.26 \\
\hline Oals. . & . & . & . & . & . & . & . & 19.00 & $5.41 ;$ & 2446 \\
\hline Barley. . & . . & . & . & . & . & . & . & 20.80 & 4.83 & 25.63 \\
\hline Indialil corn. & . & . & . & . & . & . & . & 23.00 & 4.52 & 27.52 \\
\hline Buckwlieat. & . & . & . & . & . & . & . & 17.20 & 3.75 & 20.45 \\
\hline Average hay & . & . & . & . & . & . & . & 12.80 & 4.93 & $17.7: 3$ \\
\hline 'Timotiyy laty & . & . & . & . & . & . & . & 12.411 & 5.28 & 17.658 \\
\hline Clover loay . & . & . & . & . & . & . & . & 15.40 & 622 & 21.02 \\
\hline Cilt straw & . . & . & . & . & . & . & . & 9.40 & 2.07 & 11.47 \\
\hline Corn folder. & . & . & . & . & . & . & . & 10.60 & 4.83 & 15. $4: 3$ \\
\hline Potatoes. & . & . & . & . & . & . & . & 6.00 & 1.32 & 7.82 \\
\hline 'Turuips. & . & . & . & . & . & . & . & $2: 20$ & 0.65 & 2.85 \\
\hline
\end{tabular}

The True Cost of Food. - In estimating the real expense involved in the fors fumished to stork, the value of the fout as a souree of fertility to the farm shomlal he aleducted from its cost or market value. The results will valy willoly with the variation in market priecs.

The following table will illustrate this joint:

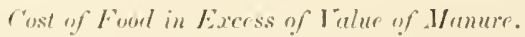

\begin{tabular}{|c|c|c|c|c|c|c|c|c|c|c|}
\hline \multicolumn{8}{|c|}{ Kinds of Food. } & \multirow{2}{*}{$\begin{array}{c}\text { C'ost per } \\
\text { 'Ton. } \\
\$ 2000\end{array}$} & \multirow{2}{*}{$\begin{array}{l}\text { Yalue of } \\
\text { Mlawure. } \\
518.13\end{array}$} & \multirow{2}{*}{$\begin{array}{l}\text { True c'ost } \\
\text { of liceed } \\
8 ! 1.87\end{array}$} \\
\hline Colton-seed n & & & . & . & . & . & . & & & \\
\hline Linseded meal & . & . & $\dot{.}$ & . & . & i. & . & 29.061 & $12.9 \%$ & $16.11 \%$ \\
\hline Wheat briu. & . & . & . & . & 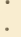 & i. & ; & 20.010 & 9.31 & 10.169 \\
\hline Oats. & & 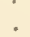 & . & . & 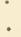 & . & . & 25010 & 5.46 & 19.54 \\
\hline Indian corn & & & . & 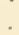 & 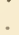 & . & . & 18.011 & +52 & $1: 48$ \\
\hline Average liay & ${ }^{\circ}$ & • & . & . & 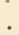 & . & . & 1200 & 4.93 & 7.07 \\
\hline Clover hay & . & . & . & . & . & . & 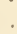 & $1=0 n$ & 622 & 678 \\
\hline (bit slratw & : & i. & : & : & . & $\dot{.}$ & . & 5.100 & 2.07 & 2.!:3 \\
\hline
\end{tabular}


Digestion. - The purpose of digestion is to dissolve food and change its nature, preparing it to enter the bloorl, and to sustain the life and growth of the body. As the food of plants is slowly prepared to enter the sap) by chemieal processes in the soil, so the food of animals is prepared in their digestive organs to enter the blood by similar processes, althongh much more rapidly.

The Mouth. - The process of digestion begins in the month. The food is not only ground into a fine condition by mastication, and better prepared for chemical action, lut is also mixerl with the saliva.

This is a liquid consisting mostly of water, but containing substances suited to procluce some chemical action upon the food. It is secreted,

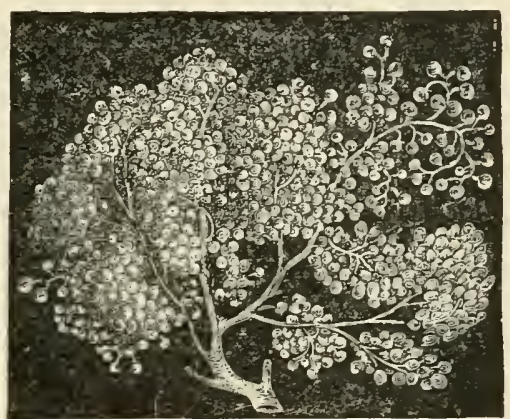

One of the Salivary Glands. or separated from the bloml, ly a number of organs called glands, situated in different parts of the month. As the blood passes throngh these glands, the saliva is taken from it and poured into the month as it is needed to moisten the food. It is formed quite rapidly while the animal is eating. It is said to be prodnced in the mouth of a horse or an $0 x$, at such times, at the rate of forr quarts per hour.

The Stomach and Intestines. - Ifter the food which has been moistened by the saliva passes into the stomach, it is mixed with other liquids, which are withdrawn from the blood and poured into the stomach. 
The mixture is kept constantly in motion by the action of the muscular walls of the stomach, until the food beennes softened or dissolved. It then passes into the intestines.

'The intestines consist of a long tube folded together' so as forecipy a small space. The portion nearest the stomach is the smaller in diameter, and is ealled the small intestine. 'The remainder is larger', and is ealled the lare intestine.

'The intestines of an ox have an arerage length of ahout 150 feet, and those of a sheep or a pig of about 90 feet.

ln the intestines, the food is still further mixed with chemical liquids, and converted into different forms. As it is thus rendered suitable for nourishment, either in the stomach or the intestines, it is absorbed by the membranous lining, and passes through minute tubes called the lactruls into the blood-ressels, to be carried by the circulation of the blood to all points of the system where it is needed.

The Stomachs of Ruminants. - Such animals as the cow, the sheep, and the goat are called mumants, because they ruminate, or "chew the cud."

As these animals naturally live npon food containing large quantities of hard, wooly fiber, their digestive system is different from that of other animals whose ford is more concentrated and more easily digested. 'The chicef point of difference is, that, in addition to the regular stomach of other animals, the ruminants have three preliminary stomachs in which eoarse food is prepared to enter the stomach proper.

The first stomach, or paunch $(p)$, into which coarse food first passes as it is swallowed, is very large. It is 
several times as large as the other three stomachs combined. In a large ox it contains about sixty gallons, and ocenpies nearly the whole length of the left side of the abdomen, or internal carity of the body baek of the lungs.

The second stomach $(b)$ is in reality only a part of the first, as there is a free passage connecting the two. 'The membrane lining its interior is euriously formed into an arrangement of cells like honeycomb.

The third stomach $(f)$ is provided with a great number of hard, hooked projections, which hold the food until it has been rendered fine enough to pass through into the fourth stomach.

The fourth stomach $(c)$ is the true digesting stomach,

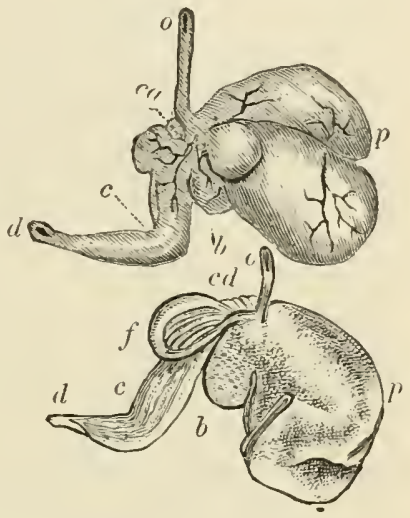

Stomach of a Ruminant. corresponding to the stomach of the horse or the pig.

The gullet, or tube (o) through which the food passes from the mouth to the stomach in swallowing, is, in ruminants, provided at its lower end with a peculiar canal, by which the food as it is swallowed may pass either into the first two stomachs on the one hand, or on the other hand into the third stomach. All food of a coarse, fibrous nature generally passes into the first two stomachs, but that which is fine and soft, requiring no further preparation, may pass at once into the third and fourth stomachs.

Rumination. - Rumination, or the chewing of the cud, is a very interesting process. As the first stomach is 
well filled, partly with solid food, and partly with liquids, a small guantity of the food near the lower entrance to the gullet is Hoated upward by the liquid into the month by a slight contraction of the stomach. The animal glasps the solid part in its mouth, swallows the liquid, and proceeds to masticate the food, reducing it to a fincr and softer condition. As this is again swallowed, such parts as are suffiejently fine and soft pass into the thind and fourth stomachs, and the remainder passes into the paunch to be returned to the month a second time.

In order that rumination may go on, it is necessary that the panneh be quite well filled, and that there shall be enough liquid to separate and float the solid food freely.

Ruminants, when supplicd with sufficient water, are able to live without food for a long time, as they are able to make use of the large store of fool in the pannch, which is gradually reduced to a fune condition, and passed along to the fourth stomach and intestine (d) for digestion.

The Blood. - The blood, in its cirenlation, is the earrying system of the animal horly. The tubes through which it passes beeome so small by subdividing that the blood is practically brought in contact with, and moistens, all parts of the system.

As the substances formed from the food pass from the stomach and intestincs into the blood, they are immediately carried forwarel with the enrrent and distributed through the system.

The blood is foreed along by the pumpling action of the heart. On leaving the heart, it passes into large tubes called arteries (a, a, a). These soon begin to subdivide into smaller arteries, and these again into still 
smaller, until they become a multitude of minute tubes, called cupillaries, passing throngh every part of the body. At length these again gradually unite in veins $(v, v, v)$, through which the blood is returned to the heart. It is

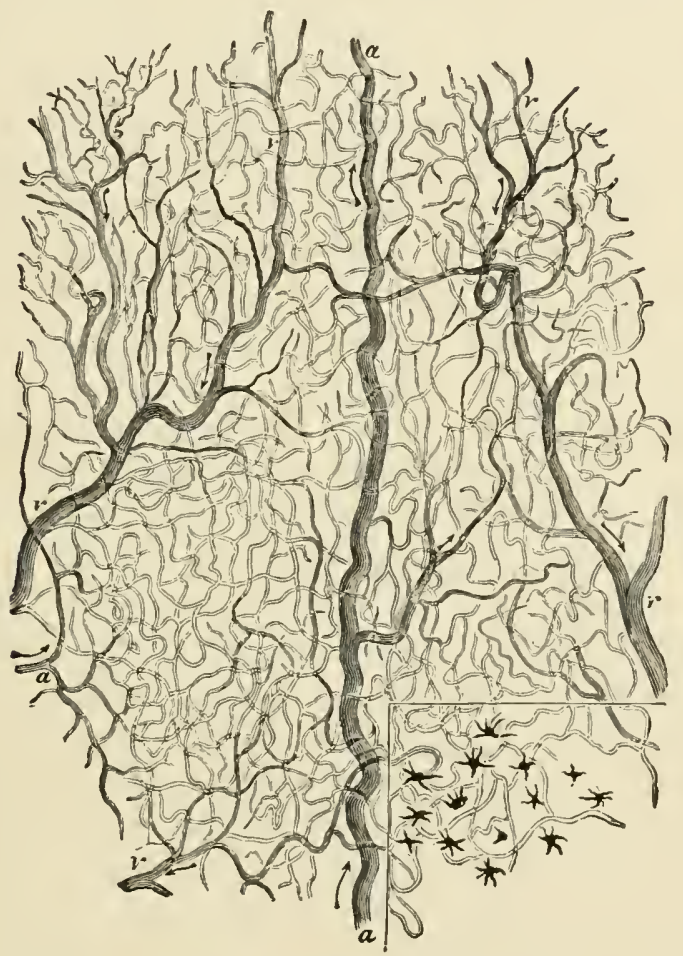

Arteries, Capillaries, and Veins.

then sent out throngh another set of tubes, which conduct it throngh the lungs, where it is brought in contact with the air taken into the lungs in breathing, becomes purified, returns to the heart, and starts again on its original conrse. 
'The blood consists of a colorless fluid, eontaining an immense number of little flattened disks, called corpuscles. Most of these are red, and give the blood its color.

The purpose of these disks seems to be to absorb oxygen from the air in the lungs, and carry it through the body, matil it is needed to oxidize the elenents of food in the blood, or the tisstes of the body.

As the disks retum from the lungs they have a bright red color, which is supposed to be due to the presence of oxygen that they have absorbed. On returning to the heart, after passing throngh the body, they assume a purple shade.

The elements of food in the blood are burned. or oxidized, by uniting with the oxyen of the corpuseles, producing animal heat or force. Particles of the body are also oxidized and replaced by new particles.

Excretion. - The bloud niot only brings together food and oxygen to produce this oxidation, but carrics away the waste products.

When the carbo-lyydrates and fits of food are hurned in the system, the result is carlonic acid and water. When nitrogenous substances are burned, not only carbunic acid and water are produced, but also certain salts, the most important of which is called urea.

Carbonic acid escapes from the blood partly through the skin, but mostly through the hungs: nrea and other salts, thromeh the kidneys; and water, through the skin, lumes, and kirlncys.

The Nature of Animals. - An animal upon the farm may he regarded as a kind of machine, eapalsle of performing a certain amount of work.

This work eonsists in converting food into flesh, milk, wool, etc., or into mechanical foree, for the service of 
man. The better the animal, the better the work alceomplished.

A loconotive engine supplied with water and fuel is able to draw a train of ears. Another cheine, mole perfectly constructed, hut supplied with the same amomt of fucl, might prodnce foree enough to draw a train much heavier. The same is true in feeling animals. Economy and profit in stock husbandry require that pror animals shall be discarded, and that the crops of the farm shall be fed only to such as are able to render good returns.

Health. - The health or thrift of animals is a matter that should receive careful attention. As good health promotes comfort, we should eare for the health of our animals on the ground of humane treatment. But the question has a practical bearing also upon the profits of feeding. The more rigorous the health, the greater the returns for the food. One animal may thrive and increase in weight upon food with which another, in less vigorous health, would grow poor.

One eow with the same food as another may produce much more milk, on account of being in better health, and possessing greater 1rower to digest food.

Breeds. - By the law of heredity, animals tend to transmit to their young their own qualities and peeuliaritics. It is therefore important, in selecting yomng animals to be raised, to make choice of those deseended from animals known to possess desirable qualities.

The common pure breeds are simply families of animals whose ancestor's were selected for their excellenec in certain directions.

The arlvantage of thorouglibred animals eonsists in the fact that they possess certain particular qualities in 
"t higher degrese than others. An oplortmity is offered to choose such hroeds as alle best adapted to the purpose repuired. One hreed of eows may have a matural tenleney to take on fat, or morbee beef, while another will tend to produce milk. One breed of horses is adapted for speed, and another to draw heary loads. Fome brexels of piges will fatten lapidly while yomeng and others not until they become older and lareger.

Eeonomy requires that we select such breeds of the diflerent animals as possess in the most marked degree the peculiarities required for the special purpose to which they are deroted.

Care. - The general care and treatment of animals is as much a source of profit as a matter of sontiment. 'T'o shelter stock in warm stables in winter prevents a loss of animal heat. The amount of foor required to keep the body warm depends largely upon the question how fast the body is couled from without. When stock is kept in tightly built stables, the warmth from the body is not removed by drafts, hut remains to elevate the temperatme of the air in the stable, and so provents a rapid cooling of the animal.

Food that is not neerled to produce animal heat is free to serve other purposes. The extra food required to keep up the temperature of a hesd of animals in a coll apartment wouhl, in a single winter, pay the cost of rendering the apartment tight and warm.

Kindness. - There is porit as well as sentiment in "kimburss to animals." 'The dierestive and mututire processes ato lategely influeneod hy the eomlition of the nerrous system. Animals whinh are disposerel to fight or amooy cach other will not thrive so well as if kept apart, or in more comgenial company. A horse with an irrita- 
be driver will grow- poor, while with kinder treatment and the same feed and work he might maintain a good condition.

It is true of the lower animals, as of man, that "it is worry, and not work, that kills." Many a farmer reduecs the income from his stock by abusive treatment.

Conclusion. - A knowledge of the principles of agrieulture is simply a knowledge of some of the laws of nature, which have a divine origin.

To minerstand these principles, and to observe them in practice, is simply to place ourselves in conformity with natural laws which are based npon the strictest propricty and economy.

Suecess and failure in agriculture turn mpon this point. The heedless and indifferent can never receive so large a share of the bounties of our mother Earth as those who are on the alert to catch the lessons which natrue teaches, and to profit by them. "If ye be willing and obedient, ye shall eat the good of the land."

\section{QUESTIONS.}

What are the two forms of life? What is the ehief purpose of regetation? Am the bodies of animals eomposed of the same materials as plants? What is the difference between herbivorons and carnivorous animals? What is the nature of the process of animal life?

Name the different elasses of substances in the body of an animal. What proportion of the horly is water? What is the nse of water in the body? What parts of the body are composed of nitrogenons sulstances? Where is fat to be fomnd in the body? Explain the different kinds of fat. What elements are included in the "ash"?

What are the different purposes of food? What nse do young animals make of food different from mature animals? Do the borlies 
of mature animals remain eonstantly the same? What is the somree of muscular power": How is animal heat supplied by foot? It what temperature must the body be kept? Ilow is it cooled when tou warm in hot weather?

(If what substances is ford composed? Are any kinds of food absoIncely dry? Ilow much noistnre do some succulent foods contain? "What are the albuminoids of fool? What parts of the body do they form? Mlay they he neel to produce lueat? Is this an eeonomical use of them? Nime some kinds of food which are especially rich in albuminoils. C'mlel an animal liwe entirely upon albuminoids? What are the amiles? In what kinds of food are they dhiefly found? IIow d, they differ from albuminoids? What is protein? What uees are made of the fats of fool? Why can they not be userl for construeting the tissues of the body? Name some of the different kinds of fats. Name some articles of food which are rinl in fats.

What are the carbo-hydrates? Why are they so called? What use is made of them? How valuable are they? Could an animal live entirely upon fats and carbo-hydrates? Name some linds of food which are largely composed of carbo-hydrates. II as woody fiber any value as food?

What is meant by the "asilu" of foors? Of what substances is the ash composed? Are these substances escential in the food of animals? Name some kinds of food which are espeecially rich in albuminoids. Name some in which the fats and earbo-lydrates preponterate.

Upon what does the value of food depend? Ilas the indigestible part any value? Name some kinds of foor which are wholly digestible. Name some kinds of which a large part is indigestible.

What two rules shond he generally followed in feeding stock? Why shemld animals crenerally be ferl as much as they can digest? Is there danger in feeding tow much? What is meant by a "balaneed ration"? Why is a part of a ration that is not well balanced wasted?

What is the nutritive ratio of a food? How is a balaneed ration marle up)? Nance articles of food which might be combined to form a proper ration for oxom at work. For fattening slieep. What is the arlvantage of furnishing a variety of forl?

What is meant by the "manurial value" of food? How is this value 
determined? Is the manurial value of the same variety of food always the same? Are the manurial substances of the same value in whatever food they are found? Name articles of food which have a high manurial value. What is the difference between the manurial value of food, and the value of the manure from the food? What items must be dedueted from the one to obtain the other? What cireumstances increase and diminish this difference?

What are the two values of fooll? How is the true eost of food to be reckoned in farming? Name articles which eost but little according to this nethorl of reckoning.

What is the purpose of digestion? Do plants digest their food, like animals? How does digestion begin in the month? What is the saliva? How fast is it formed? Explain the action of the stomael. Describe the intestines. IJow long are they? What lecomes of the foorl after it is ligested?

Name the animals called "ruminants." Why is their digestive system different from that of other animals? What is the ehief difference? Describe the first stomach. What is the second stomach?

What service does the third stomach perform? Whieh stomach corresponds to that of other animals? Into which stomach does the food first pass, when swallowed? In what way is the "cud" bronght to the mouth? Into which stomach does it pass when swallowed again? What may be the difienlty with animals unable to ehew the eud? Why are ruminants able to live longer withont food than other animals?

What is the nse of the blood? In which parts of the body is it to be found? Describe the system of tubes through which the hlood passes. Why does it pass through the lungs? Of what does the blord consist? What is the purpose of the corpuscles? From what does hood derive its eolor? Why is the eolor different in different parts of the body?

What other office does the blood fill hesides conveying nomishment to the body? Name the other waste products of the body besiches undigested foot. Name the different methods by which they eseape from the hody.

How does an animal resemble a machine? Why is one animal more profitable than another for a given purpose? For what two reasons should the health of animals be cared for? 
What is the origin of lifferent breeds of animals: What advantage is there in thoronghbred animals? What advantage is there in a variety of breeds? Why is it profitable to provide sheiter for stock? For what two reasons shoull animals receive kind treatment? How does unkind treatment reduce the ineome from animals? 


\section{GLOSSARY.}

Al-bū'mi-noids. . $\Lambda$ elass of substances in foods which contain the most of the nitrogen.

Al'ka-li . . . . A A class of bases including ammonia, soda, potash. etc.

Al'ka-line .... Resembling or possessing the qualities of the alkalies.

Al-lū'vi-al . . . P Pertaining to a river. Allnvial deposits are de josits from the washing of rivers.

Am'rdes . . . . A A class of substances contained in foods.

An-ti-cy'clone... The opposite of eyclone. Winds moving in the opposite direction from those of a neighboring storm, or eyclone.

Ap'a-tite . . . . $\Lambda$ greenish mineral composed of phosphate of lime. As-sim'i-late . . . To convert the food into the substances of the body. Cal-ca're-ous ... Consisting of lime, or containing lime.

Ca'lyz........ The onter eorering of a flower.

Cap'il-la-ries.... The smallest tubes through which the blood passes in its circulation.

Car-bo-hy'drates . $\Lambda$ large class of sulstances in foods, composed of carbon, lyydrogen, and oxygen.

Car-bo-na'ceous. . Containing earbon, or emposed of carbon.

Car-niv'o-rous... Feeding "pon the flesh of animals.

Cel'lu-lose . . . A A sulstance of which the membranes of cells of plants are largely composed.

Con-glom'er-ate. . Heaped together.

Co-rol'la . . . . . . The inner covering of a flower.

Cor'pus-cles .... Minute, clisk-shaped particles, floating in the blood.

Cot-y-lē'don . . . . One of the two seed leares of a plant which first appears.

Cy'clone ..... A storm, the winls of which blow in a circuit.

De-com-po-si'tion. Decay, or a chemical change into other substances. 
Dis-in-te-gra'tion . Destrution, or separation into parts.

Ex-crētion. . . . 'lhrowing off nseless matter from the animal sistem.

Glā'cier . . . . . . . in inmense mass of moring ice.

Her-biv'o-rous . . Eating herls. living npen regatation.

Hin'mus . . . . . \ lark or browu sulstance, commen in soils.

In com-bus'ti-ble. Not (apsable of heing lmmed.

I'so-bar . . . . . \ line indieating the points where the height of the batrometer is the salme.

I'so-therm .....A line indicating points where the temperatme is the silule.

Lac'te-als . . . . P. l'asiges throngh which blood is conveyed from the stomach and intestines to the blood-ressels.

Le-gū'mi-nous... I'ertaining to a class of plants, including peas, beans, elover, ete.

Ni-tri-fi-ca'tion . A natural process by which uitrates are formed in the soil.

Ni-trog'e-nous . . Pertaning to nitrogen, or containing nitrogen.

O'le-in . . . . . . The oily part of foods in the animal body.

Pal'mi-tin..... One of the kinds of animal fat.

Pet'ri-fied . . . . . Converted into stone, or into a sulstance like stone.

Plū'mule . . . . . 'The first bud, or ascending part of a young plant.

Pro'te-in ..... . 'Those parts of food which furuish nitrogen.

Ru'mi-nate.... To To chew the curl.

Ru'mi-nant .... An animal that chews the cud.

Sal'i-va-ry .... l'reducing saliva.

Se-crete' . . . . . To separate; as to separate fluids from the blood.

Ste'a-rin....... One of the hard kinds of fat in the animal boty.

Sto'ma-ta ..... Minute mouths or openings on the surface of leaves.

Tu'ber-ous . . . . Covered with or containing tubers.

U're-a . . . . . One of the waste substances of the system, separated from the blood by the kidneys. 


\section{N D E X.}

A.

Absorbing power of ruots . . 68

Absorption, of water by plants . 62 of ammonia by plants . . 62

Acids

Acids, bases, and salts . . . . 12

Adhesion . . . . . . . 14

Agre of the earth . . . . . 27

Agriculture, effect of . . . 78

Air, composition of . . . . 41

necessary for roots . . . 101

purified by plants . . . . 1 .

Albuminoids . . . . . . . 118

Alkalies . . . . . . . 13

Alum . . . . . . . . 17

Alumina . . . . . . . 23

Aluninjum . . . . . . 2:3

Allurial soil . . . . . . 32

Amiles . . . . . . . 119

Ammonia . . . 11, 13, 18, 21

absorbed by foliage. . . 62

carbonate of . . . . . 82

formation of . . . 81,82

Ammonic chloride . . . . 13

Animal heat . . . . 11\%, 140

Animals, remains of . . . 37

breeds of . . . . 139, 140

care of . . . . . . . 140

composition of bodies of . . 114

health of . . . . . . 138

kinduess to . . . . . 140

nature of . . . . . 138

young. . . . . . 116

Apatite . . . . . . . 85

Application of fertilizers . . . 89

Application of manure . . . . 94

Arteries, the . . . . . 136, 137

Artificial fertilizers . . . . 33
PAGE

Ash of animal bodies . . . $11 \mathrm{t}$

of food . . . . . . 120

Atmosphere . . . . . 31, 41

weight of . . . . . 42

Atomic theory . . . . 8

Atoms . . . . . . . 8, 11

B.

Balanced ratiou . . . 124, 125

Barometer . . . . . . 43, 44

Bases . . . . . . 12, 13

Beans . . . . . . . . 62

Beets . . . . . . . 63

Biennial plants . . . . . 62

Blight . . . . . . . . . 69)

Bloor, the . . . 15,6, 137, 138

Blue litmus . . . . . . . 66

Bodies of animals . . 114, 115, 116

liones as a fertilizer. . . . . 84

lione-black . . . . . 84

Bowlders, origin of . . . . . 34

Breathing . . . . . . . 137

of plants . . . . . 61,62

Breeds of animals . . . 139, 140

Breezes . . . . . . . . . tij

Brimstone . . . . . . . 24

Buttercups, roots of . . . . . 63

C.

Calcareons soil . . . . . . 39

Calcium. . . . . . . . 23

carbonate . . . . . 23

hydrate . . . . . 86

oxille . . . . . 19,86

phosplate . . . . . . 22

Calyx . . . . . . . 74 


\begin{tabular}{|c|c|c|c|c|c|c|c|c|c|}
\hline & & & & & P.AGE & & & & Page \\
\hline Canada thistles & . & & & . & . 63 & Combustion . . . & . & . & . $\quad 20$ \\
\hline Cane sugar . & . & . & & - & 12 & Composition of foods & . & . & . 118 \\
\hline Cap of roots. & . & . & & . & 64 & of soil . . . & . & - & . $7 \pi$ \\
\hline Capillaries, the & . & . & . & . & . 137 & Continents, formation & of & . & 27 \\
\hline Capillary attract & tion & & & - & . 67 & Cooling of the body & . & - & - 118 \\
\hline of roots. & . & . & & . & 68 & Coral reefs. . & . & . & 37 \\
\hline in plants. & . & . & & . & . . 71 & Corn meal, effects of & . & . & $1: 20$ \\
\hline ('arbo-hydrates & . & . & & . & $119,1: 0$ & Corpuscles. . . & . & . & 138 \\
\hline ('arbon. . . & . & . & & . & . . 21 & Cotton. & . & - & 70 \\
\hline from the air & & . . & & . & - $\quad 60,61$ & tiber. . & . & . & 73 \\
\hline Carbonate of an & mol & mia & & . & . . 82 & Cranberry plants & . & . & 101 \\
\hline Carbou dioxide & - & . & & - & •. 19 & Crops, rutation of & . & . & 110 \\
\hline Carbonic acid . & & 3,14 & & 18, & $19,20,41$ & Crystallizing . & - & . & 19 \\
\hline absorbed by & pla & & & . & . 61 & Crystals of snow. & . & - & 17 \\
\hline in the anim: & & yste & & & . 138 & Cultivation . . & . & & . 100 \\
\hline in the soil & & & & . & 101 & deep & . & $\cdot$ & 107 \\
\hline Carboniferous v & eget: & tatio & & . & . $\quad 39$ & of lived crops & . & - & . . 107 \\
\hline Care of animals & & & & . & . 140 & purposes of . & . & . & . $100-103$ \\
\hline Carnivorous ani & mals & & & & 114 & sliallow . & - & - & . . 107 \\
\hline
\end{tabular}

Carrots . . . . . . 63

Caustic potash . . . . . . 29?

Caustic soda . . . . . . . 23

Cells . . . . . . . 68

form of . . . . . 70

growth of . . . . . 69

of a potato . . . . . 69

of ripe fruit . . . . . 69

Cellulose . . . . . . 1;0

Charcoal . . . . . . 21

is a filter. . . . . . 14

Chemical action . . . . . . 11

in soil . . . . . 80

Chemical affinity . . . . s

Chemical equations . . . . . 12

Chemicals, use of . . . . . 88

Chewing the cud . . . . 135, 136i

Chlorate of potash . . . . . 23

Clulorile of potash . . . 13, 85

Clnovine . . . . . . 22

Circulation of the blood . . . 136

('lay . . . . . . . 22

Clayey suil . . . . . . 38

Climate . . . . . 50,51

Clourts . . . . . . . 47 47

Clover . . . . . $122,633,73$ roots . . . . . . 134

Coal, origin of . . . . . . 37

Colpesion . . . . . . . 14

Cold wave. . . . . . . . 4!

Combustible matter. . . 18

D.

Dark weatlser, effect of . . 61

Decomposition . . . . . 20

of soil . . . . . . . 101

leep cultivation . . . . . . 107

Deep plowing. . . . . . 104

Dew . . . . . . . . 48

Djamonds . . . . . . . . 21

Diffusion . . . . . . . Gin

in plants . . . . . 68,72

Digestible parts of food . . . 121

Digestion . . . . . . 1333

Jisks of the blood . . . . 1:88

1)rainagre, by deep tillage. . . 104

1)raining : . . . . . 108 coldl soil . . . . . . 110

Drains, to prevent effect of drought . . . . . . . 109

E.

Farth, its origrinal condition . . 20 its age. . . . . . . . 29 its interior . . . . . . 26

Farthupulkes . . . . . . . 26

lenomy in feesling. . . 122, 12:?

Eiferet of arriculture . . . . 78

lithrescrile . . . . . . . 14

lilementary substances . . . ४ 
Page

Equations, chemical . . . . 12

Erigenia . . . . . . . . 63

Evaporation frour soil . . . . 110

Excretion . . . . . . . 138

Exposure of manure . . . . 94

F.

Farm, care of . . . . . . 92

Furm manure . . . . . . . 90 nature of . . . . 9 90,91

Fat, animal . . . . . . 115 in food . . . . . . 119 varieties of . . . 115, 116

Feed, true cost of . . . . . 132

Fermentation of manure . . . 92

Fertile soil . . . . . . . 77

Fertility . . . . . . . . 37

maintained . . . . . 79

relluced by weeds . . . . 102

Fertilizers . . . . . . 7 artificial . . . . . 83

prepared . . . . . 85

Fiber in fools . . . . . . 120 of wood . . . . . 70

Fibrous roots . . . . . . . 63

Flow of sap . . . . 65, 72

Flowers. . . . . . 73

Fogs . . . . . . . . 47

Food of plants . . . . 60,65

Food, purposes of . . . 116, 117 digestible parts of . . . 122 quantity profitable . . . 124 variety of . . . . . 129

Foods, comprosition of . . 118, 121 double value of . . . 131, 132 manurial value of . . 129,130 true cost of . . . . 132 value of . . . . . 122

G.

Germ of seeds . . . . . 54

Germination . . . . . 57

Glaciers . . . . . . 34

Glands, salivary . . . . . 133

Glass . . . . . . . . 22

Granite . . . . . . 22

soil from . . . . . . . 79

Gan!rite
Gravelly soil . . . . . 38

Growtl, of roots . . . . . 63

of plants . . . . . 68,69

Guano * . . . . . . 85

Gullet, tlie. . . . . . . 135

Gum arabic . . . . . . 12

Gyjsum . . . . 13,87, 88

\section{H.}

Hail . . . . . . . 47

Hard pan . . . . . . 31

Harrowing, purposes of . . 106

thorough . . . . . . 106

Health of animals . . . . 139

Heat, effect of . . . . . 16 animal . . . . . 117

in germination . . . . . 58

Herbivorous animals . . . . 114

Itills. . . . . . . . 32 formation of . . . . 29,30

worn away by winds . . . 35

Hoed erops, cultivation of $\quad . \quad 107$

Humus . . . . . . . 35

Jydrochloric acid . . . 11-13,22

Hydrogen . . . . . . 20

\section{I.}

Ice, effect of, upon soil . . . 32

Impurities of the atmosphere . 42

Indian corn, roots of . . . . 64 mixture of . . . . . 74

Insects, a voided by rotation . . 112

Intestines, the . . . . . 133

length of . . . . . 133

Iron . . . . . . . . 125

\section{K.}

Kidneys, the . . . . . . . 138

Kindness to animals . . . 140

L.

Lacteals, the . . . . . . . 134

Leguninous plants . . . . . 62

Lime . . . . 12, 13, 19, 41, 86 benefit of, in soil . . . 87

Limestone . . . . , 23, 32, $3 \overrightarrow{7}$ 


\begin{tabular}{|c|c|c|c|c|c|c|c|c|c|}
\hline \multirow{2}{*}{\multicolumn{6}{|c|}{ Limestone, soil from }} & \multicolumn{4}{|r|}{$P_{A G E}$} \\
\hline & & & & & & & & & \\
\hline Limy st & & & . & . & . & . & & & 41 \\
\hline Liquid & ma: & nure & & . & . & . & . & - & \\
\hline Litmus & . & . & . & . & . & . & . & . & \\
\hline Loam & . & . & . & . & . & . & . & . & \\
\hline Lucerne & & . & . & . & . & • & & & \\
\hline lungs, & the & & . & . & . & 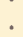 & . & . & \\
\hline
\end{tabular}

M.

Magnesia . . . . . . 13, 23

Manure . . . . . . . 90

application of . . . . . 94

fermentation of . . . . . 92

from foods, value of . . 131

losses of . . . . 92,93,94

Manurial walue of foods $129,130,131$

Marble . . . . . . 23,31

Mar] . . . . . . . 87

Mastication . . . . . . . 1333

Matter, nature of . . . . . 10

Mist . . . . 47

Moisture of climate. . . . 51, 52 in germination . . . 55,58 regulated by cultivation . 103

withdrawn by weeds. . . 102

Mold, vegetable . . . . . . 79

Molucules . . . . . . . . 9

Mountains . . . . . . 29, 32

formation of . . . . . 97

Mouth, the . . . . . . 133

Moutlis of leaves . . . . . 61

Muck . . . . . . $\$ 5,96$ value of . . . . 96,97

Muck beds . . . . . . . 35

Mucky soil . . . . . . . 39

Muriate of potash . . . . . 85

Muriatic acid . . . . . . 1;, 2:2

N.

Nitrate of lime . . . . . . 82 of potish . . . . . . 82 of soda . . . . 13, 82, 84

Nitrates . . . . . . 82 in soil . . . . . . 81

Nitric acil . . . . . . . . 1:3 in soil . . . . . 81, 82

Nitrification . . . . . 82, 83

Nitrogen . . 20(1) 41, 62, 81, 81
Page

Nitrogen as food for plants . . (i2

North Anerica, formation of . 27

Nutrition in plants . . . . . 7.2

Nutritive ratio . . . 12t, 126

0.

Oak trees, roots of . . . . 633

Ucrast, affecting climate . . . 51

soil formed by . . . . . . 32

Grganic matter . . . . . 17, 18

Usmose . . . . . . . (i2)

in plants. . . . . . 71

Oxilation . . . . . 19,20

of plants . . . . . . 62

Oxille of iron . . . . . . 13

Oxicles . . . . . . 19

Oxygen . . . . . 19, 20

in germination of plants . 5t;

itr soil . . . . . . . 101

in the blool . . . . . 61

P.

Paunch, the . . . . . 134

Peas. . . . . . . . 192

Peat . . . . . . . 35, 37

Peaty soil . . . . . . 35, 39

Perspiration, effect of . . . 118

P'etals . . . . . . . $7 t$

Phosplate of lime . . . 13,84

Phosploric acil . . 13, 22, 83, 84

Phosphorus . . . . . . . 22

Pistils . . . . . . it

Planting, deptli of . . . . 57

Plants, growtl of . . . . 1;8

breathing of . . . . . . 20

food of . . . . . 60

instinct of . . . . . .

legnninons . . . . . . 62

structure of . . . . . . 68

Plant food, formation of . . . 101

l'laster, land . . . . . 87

Plowing . . . . . 10:3, 104

subsoil . . . . . 105

time for . . . . $105,10 i i$

['lumule, the . . . . . . 5!

l'ores of word . . . . . 15

l'orosity of matter . . . . . 15,

l'otassium . . . . . . 23 


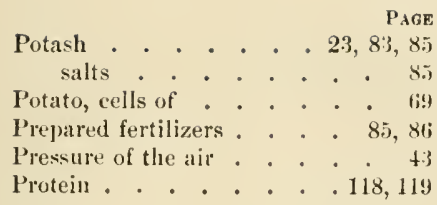

Q.

Quartz rock . . . . . 22 Quicklime . . . . . 13,86

R.

Radicle, the . . . . 59, 62,63

Rain. . . . . 42, 45, 46, 47

Rainless regions . . . . . 47

Rain water, a fertilizer . . 108

Ratio, nutritive . . . . . . 125

Ration, balanced . . . . . 125

Rations, how made up . . . . 127 examples of . . . . . 128, 129

Requirements of animi1l; . . . 127

Respiration . . . . . . 20

Rice plants . . . . . . . 101

Rochelle powders . . . . . 13

Rocks, ancient . . . . . . 30

Rolling land . . . . . . 107

Rootlets . . . . . . 64

Roots . . . . . . 63, 64

air necessary for . . . . 101

in wet soil . . . . . 108

of buttercups . . . . . 63

of clover. . . . . . 64

of the maple. . . . . . 63

tap......... 63

tuberous . . . . . . 63

Rotation of crops . . . .110-112

Riminants . . . . . . 134-136 stomachs of . . . . . 134, 135

Iiumning water, efect of . . 31

"Run out" land . . . . . . 79

S.

Saliva . . . . . . 133

Salivary grands . . . . . 133

Salt . . . . $11,12,17,65,87$

Saltpeter . . . . . . 84

Sandstone . . . . 22,31,32
Page

Sandy soil . . . . . 37, 38, 105

Sap of flants . . . . . . 65

How of . . . . . 71, 72

Salurated soil . . . . . 101

Strit breezes . . . . . . 45

Seeds . . . . . . . 54

unripe . . . . . . . 55

Selection of food by plants . . 73

Sepals . . . . . . . 74

Slaallow cultivation. . . . 107

Silicates . . . . . . . 22

Silicon . . . . . . 22, 73

Silicic acid . . . . . 13

Simple substances . . . . 7

Slag . . . . . . . . 85

Slaked lime . . . . . . . 12

Smoked glass . . . . . . 21

Smut . . . . . . . . 69

Snow . . . . . . 47

crystals . . . . . . 17

Sodium . . . . . . 13, 23

Soil, formation of . . . 27,30

alluvial . . . . . 105

composition of . . . 37, :35, 78

fertile . . . . . 77

from granite . . . . $\quad$. 79

from limestone . . . . . 79

sandy . . . . . 37, 38, 105

warmtl of . . . . . 110

Solids, liquids, and grases . . . 16

Soutl Carolina rock . . . . 8.5

Squashes, mixture of . . . . it

Stamens . . . . . . . it

Starch . . . . . . . 60

of potatoes . . . . . . 69

Stomach, t:2e . . . . 13:3, 1:4

Stomachs of ruminants . . . 1:5

Stomata - . . . . 60,61

Storms . . . . . . . 50

Subsoil . . . . . . 174

plowing . . . . . . 105

Substances, simple . . . . . 7

Success in agriculture . . . . 111

Sugar . . . . . . 19,60

Sulphates . . . . . . . 13, $8 t$

Sulphate of ammonia . . . . 84

of lime . . . . . . 13

of potash. . . . . . . $\quad$ ?

Sulplur . . . . . . . . 22

Sulphuric acid . . 10, 1:2, 21, 22, 66 


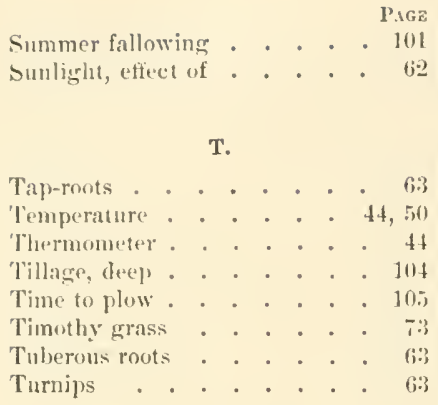

\section{U.}

Tnderdrains . . . . . 108

Tnripe seuls . . . . . . 55

Urea. . . . . . . 138

V.

Vallege, cause of . . . . 30

Value of fools . . . . . 121,122

Varjety of food . . . . . 129

Vegetable matter . . . . 35

Vegotable moli _. . . 35, 79

Vegetable tissue . . . . . 69

Vegetation, carboniferous . . :3;

Veins, the . . . . . . 197
PAfiE

Vitality of seeds . . . . . 54

Volatile substances. . . . 21

W.

Warm wave . . . . . 4?

II: armth for germination . . . 5\%

Witer, magnifiet . . . . . !

in fouls . . . . . 118

in thr aninal horly . . . 115

moleconle . . . . . . 11

vapur. . . . . . 41

Watering plants. . . . . fi.

Weather, the . . . . . 49

Weeds. . . . . . . 102

Wet land . . . . . . . 109

White clover . . . . . . 63

Wind . . . . . 34, 35, 44, 45

Wool, composition of . . . 7

Wond, porosity of . . . . 15

Work, effect of . . . . 117

Y.

Young animals . . . . . 11f

Z.

Zinc . . . . . . 11, 12

Zine calorid . . . . . . 12 



THE LIBRARY

UNIVERSITY OF CALIFORNIA

Santa Barbara

THIS HOOK IS DUE ON THE LAST DATE STAMPED BELOW. 


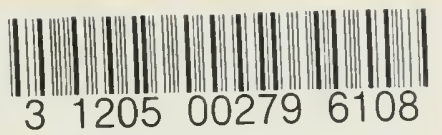

UC SOUTHERN REGIONAL LIBRARY FACILITY

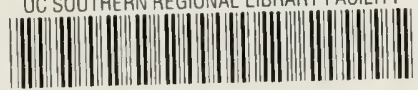
AA $000991308 \quad 8$ 
